\title{
Enabling adaptive water management to face drought risk in a changing climate
}

\author{
Index
}

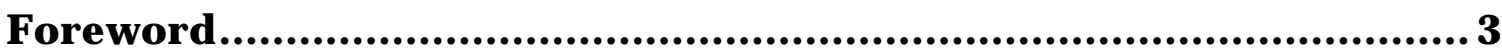

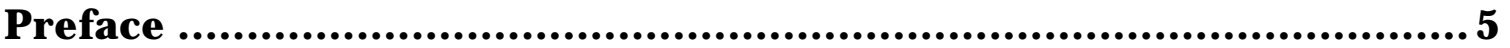

Chapter 1: Introduction ..........................................................6

Aim and Objectives.................................................................................... 8

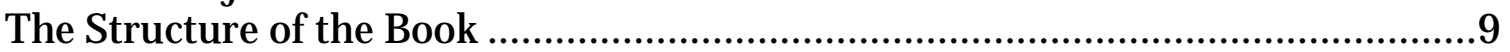

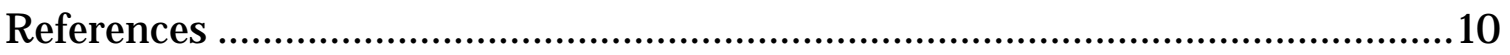

Chapter 2: Definition(S) and Impacts Of Drought.......................... 12

2.1Definition of Drought............................................................................... 12

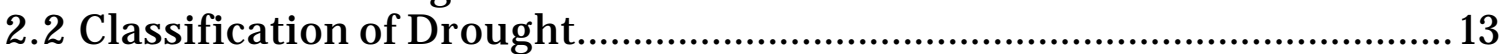

2.3 Drought in Arid and Semi-Arid Land ............................................................ 14



2.4.1 Effects of Droughts on the Ecosystems............................................................. 16

2.4.2 The Socio-Economic Impacts of Drought...................................................... 17

Chapter 3: Water And Drought Management Today .........................24

3.1 What Are Today Challenges of Water Management ......................................... 24

3.2 Responses to the Challenges ........................................................................ 26

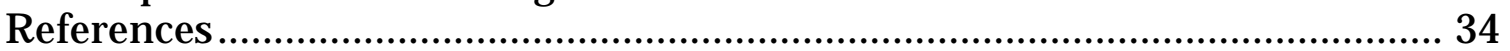

Chapter 4: How Water Management and Water Organisations

Respond to Today Challenges? .........................................................38

4.1 How Is The Water Paradigm Changing? .............................................................. 38

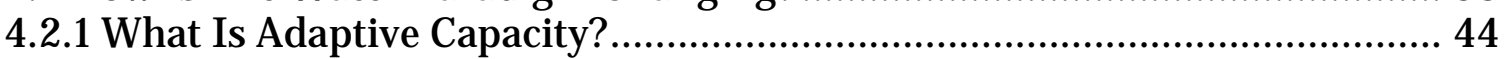

4.2.2 Linking Institutions, Organisations and Adaptive Capacity ……….................45

4.2.3 How Was the Adaptive Capacity of Organisations Assessed in Earlier

Frameworks? .......................................................................................... 46

4.2.4 Analysis of Organisation's adaptive capacity Characteristics ...................... 48

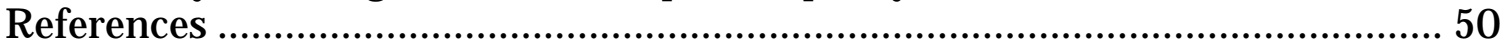

Chapter 5: React, A New Conceptual Framework for Assessing Organisation's adaptive capacity ...............................................59

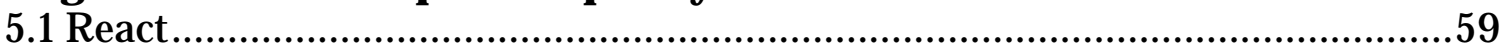

5.2 React in Action: Operationalizing Organisation's adaptive capacity ...............65

5.3 Adaptive Capacity and Time Scale. Errore. Il segnalibro non è definito.

Chapter 6: Bolivia Case Study ...................................................... 74

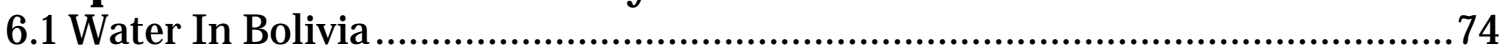

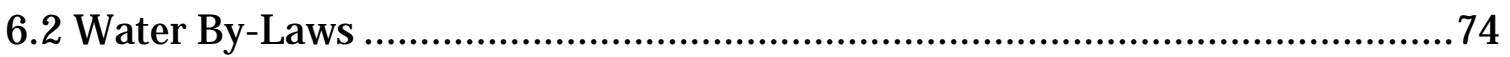

6.3 Introduction of The Study Area ..................................................................... 75

6.4 Analyses the Impacts on the Socio-Ecological System of

Past Drought Events.......................................................................................... 76

6.5 Analyses the Impacts on the Socio-Ecological System of Past Drought Events

6.6 Climate Change And Direct And Indirect Effects............................................

6.7 Facing Drought: the Early Warning System as a First Response..................... 80 
6.8 Early Warning System in the Potosí Department ............................................. 80

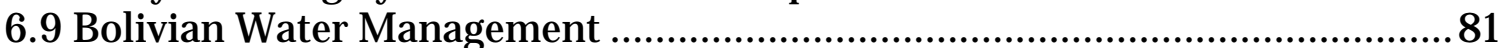

6.10 Actors Involved in the Water Management ..................................................... 82

6.11 Decision-Making and Water Organizations ................................................... 84

6.12 Towards a New Water Management Approach .............................................. 86

6.13 Water Management and the Indigenous Farmers Community...................... 86

6.14 The Water System in the Municipality of Tomave (Potosí) .............................87

6.15 Main Transformations Due to the Bolivian Quinoa Market ........................ 92

6.16 Barriers to A Water Management Paradigm Shift and

Institutional Traps.............................................................................................. 93

6.17The Role of Ngo in Fostering Adaptive Capacity of Organisations .......... 96

6.18 Interviews With Organisations in Charge With Water Resources

Management in Bolivia..................................................................................99

6.19 Adaptive Capacity of the Municipality of Tomave .......................................... 99

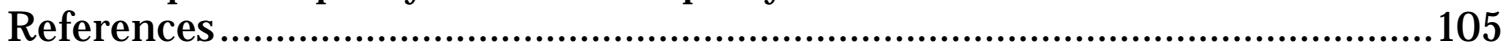

Chapter 7: Conclusion................................................................... 111



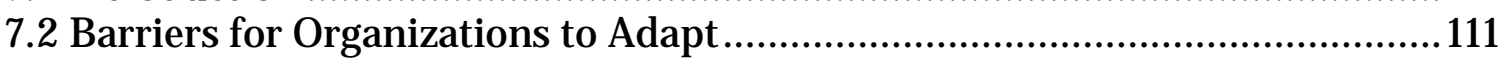

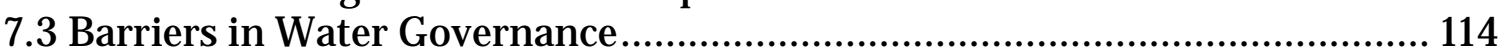

7.4 Opportunities to Adaptive Water Management Implementation ....................117

7.5 Enabling Adaptive Water Management to Face Current and

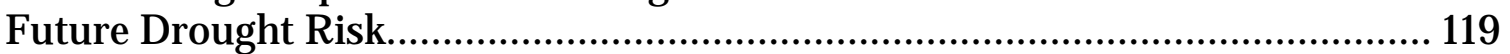

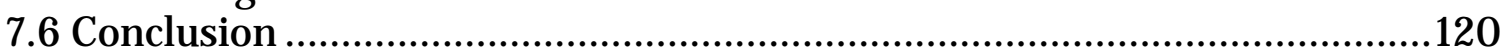

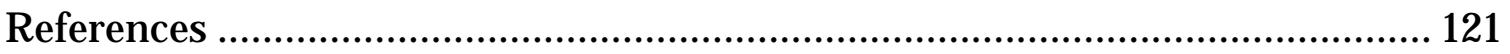

Annex 1: Questionnaire ..................................... 122 


\section{Foreword}

This book is about drought, institutional arrangements in developing countries dealing with water management, global economic drivers, poor communities in search of improved living conditions, and showing how all those issues are interacting together under changing climatic, political and socio-economic conditions. It does so by drawing on first hand observations and analysis of available literature, documents, interviews in the area of Municipality of Tomave belonging to the Quijarro Province in Bolivia. Bolivia is a relatively remote country in Latin America, for long time excluded from global formal trade connections, suddenly discovering the enormous potential of a seed, the quinoa, particularly appreciated for its nutritional qualities in countries that have internationalized their taste and seeking healthier food. The quinoa production of the quinoa is increasing rapidly, demanding a more considerable amount of water, at the expense of other plants and it is creating new problems of sustainability. The latter are experienced not only environmentally but also as far as the local diet is concerned: whilst the quinoa was traditionally providing the basic food for Bolivian people, its discovery as a lucrative product has turned it into a good for exportation, thus depriving many of its consumption without providing equally valid alternatives.

By entering into the specific dynamics that characterizes the Bolivian case study, the Author describes how development is somehow forced by international competition over global markets to take unsustainable paths, that are in the medium and longer term detrimental for the well being and even the survival of communities that are hoping instead to improve their rather poor conditions. It is a rather well known trend that globalization has somehow stretched to the extreme: unsustainable social and living conditions push people searching for improvements that obey to the laws of free, global markets, resulting in decrease of poverty but at the expense of environmental sustainability. On the balance the trade is between livelihood and environmental sustainability, where the impact on the latter means the erosion of the vital basis of the former. Finding an equilibrium between the two should be the objective of what Guido Minucci proposes as adaptive water management and planning. A concept that is not new and actually very much debated especially in more recent years. Nevertheless operationalizing it, turning it into an actual opportunity for finding the balance between contrasting needs operating at different spatial and temporal scales is not as easy to do as to say. In fact, one must be aware that forces that are playing on this ground are shaped across different spatial scales: the consumers of the goods are far from where the damage to natural resources is suffered and the marketing campaigns actually promote them as healthier and also providing the source of enhanced living standards for producers, which is partially true. As for the temporal scale, the benefits are now, whereas the harm will be brought in the future, a situation that is common to most environmental hazards and risks. Such complex interrelationships make it rather difficult to implement adaptive management only locally, where the goods are produced, or even at the national level, where decision makers see their commercial balance pending on the positive side as for export and GDP. What makes the analysis and the insights on the different dimension political, social, institutional, environmental of the case study so relevant stems from the deep knowledge that the Author has developed by living in the area and therefore getting to understand processes and practices in the everyday life and not just as a stand alone result of few visits to the area. The experience matured and 
lived through in the municipality of Tomave provided him with the possibility to identify specific aspects that can be leveraged on, albeit in a very difficult context, in order to achieve enhanced adaptive water management practices.

The book is organized in an interesting manner, as it first proposes a framework, named React, to combine the clear identification, description of the problems entailed by current water management practices making explicit the different drivers acting at different scales, with the proposal of solutions that result from a process to be triggered among a variety of stakeholders. Such process puts at the centre a set of capacities including collective and individual learning, sharing of information, improved practices of decision-making and negotiation. Then the framework is tested in the case study of Bolivia, revealing the many obstacles that it would face in case of adoption. In the concluding chapter, the Author provides ideas grounded on evidences from the field on how the framework can still provide a significant added value and potentially lead to much more sustainable solutions and practices if local actors who are facing the consequences of ill water management are able to innovate from inside current governance practices triggering a season of reforms. It is acknowledged that thelatter cannot be achieved all at once, but priorities must be set based also on what is achievable and what can be used as a leverage to trigger more vertical and horizontal coordination among social groups and institutions. One way to do this is perhaps working to improve drought early warning systems that address immediate issues that are already experienced by all (or most) stakeholders and then demonstrate that better water management can significantly reduce the number of warnings, by pushing away critical thresholds from the most frequent conditions of seasons with scarce rainfall. The entire book is in fact based on the I believe correct assumption that whilst drought is a natural phenomenon, water scarcity is experienced primarily because of ill designed water systems and lack of adaptation to climatic conditions, even without fully considering the impact of climate change. And, correctly the Author begins with a multifaceted and articulated explanation of drought, that differently from other "natural" hazards, does not correspond to an agreed upon, univocal definition. This apparently odd situation stems from the fact that drought is conceived and perceived differently upon the usages of water rather than referred to indisputable precipitation values. It is also the result of the nature of drought, that differently from floods or storms, is a creeping and long term duration hazard both in its outbreak and in the consequences it produces in social and natural systems.

By interlacing a disaster risk reduction with an adaptive water management and planning perspectives, the present book provides a useful contribution to a field of research and practice that is at the frontier of various disciplines and organisations that have at the end no other choice than cooperate for the survival of communities and ecosystems without which also the conditions that permit to some to get richer and better are severely undermined. 


\section{Preface}

Drought is a severe weather-related natural disaster affecting the extended area and ranking first among all natural hazards in terms of the number of people affected, putting society and environment at risk in many regions of the world. Droughts of even greater intensity will likely increase in the coming years, and other stresses related to global market-driven transformations and population growth will compound the effects of climate variability and change on water resources.

The traditional water management is now considered inadequate to respond to uncertainties and extremes expected with climate change and other contextual conditions. As a result, water management has shifted towards iterative and integrated management practices, more aligned with concepts of adaptive water management.

The book examines the drought risk characteristics and the specificities of the impacts of droughts firstly. Then it explores the current challenges and the context of high uncertainty and high risks for water management as well as the interlinkages between drought and water management. The book focuses on the challenges to water organizations, requiring the ability to adapt to such changes and implement adaptive water management.

The characteristics of the adaptive capacity regarding organizations and institutions have been identified and investigated through a critical review of the relevant literature. Reframing such characteristics, the book proposes a conceptual framework to assess organisation's adaptive capacity, named REACT. The developed framework has been tested within a case study in Bolivia.

The book analyses the barriers hindering the adaptive capacity of organizations that administer water to adapt, such as a low level of organisational and individual learning capacity, a lack of sharing and negotiating, leadership and resources. It also investigates the socio-cultural and economic barriers in the water governance for applying the AWM strategies that include institutional legacy and fragmentation, lack of resources as well as corruption and elite pressure.

The book describes how to enable adaptive water management to face current and future drought risk by integrating it with drought risk management, for instance, promoting policies that endorse watersheds protection and drought plans strengthening water management capacity within water users and managers.

The findings outline that an adaptive approach to water management integrating drought risk management facilitate a context with flexible and open water management organizations and governance systems that allow for learning and increase adaptive capacity to embrace climate and non-climatic drivers uncertainties in decision-making and design solutions that reduce vulnerability to ensure sustainable development. 


\section{INTRODUCTION}

Abstract. The book was set out to explore the ways to enable adaptive water management to face drought risk in a changing climate by focusing on water management organizations. This chapter sets the background shortly and introduces the problems. Moreover, it outlines aims and objectives of the research. Finally, it provides a road map for the rest of the book.

Water is a shared resource, and its management needs to take into account a wide variety of conflicting interests. Water fulfils various functions indeed for very different usages and users. Therefore, water is valued differently by various groups of stakeholders. Furthermore, water is also dealt at different levels (multi-level) and by different actors (multi-actors) in the market, society and government. As long as the water is abundant relative to its use, these interaction effects may not be noticeable. Moreover, natural water supply varies over time, and some variability can be compensated by the buffering capacity inherent in the water system such as natural storage or adaptation in water use patterns. However, a in dry climate, or as water use and pollution rise, the externalities become problematic without institutional arrangements to clarify rights and responsibilities. In this context, thus, extreme events, such as droughts, putting a strain on competing uses have always been one of the significant challenges for water management.

This book focuses on water management in the drought-prone country of Bolivia. It particularly emphasizes the role of adapting water organizations and processes to face drought impacts, which pose fundamental challenges to water policymakers as they imply complexity, scientific and political uncertainties.

In the late 1970s and early 1980s, the message of new institutionalism was put to the forefront: that institutions in general and state institutions, in particular, are essential for and make a difference to the collective choice processes (Ferragina et al. 2002). New institutionalists assume that administrative systems influence society and overall the environment, where relationships between citizens, private agents, and public organisations unfold. The new thinking on the importance of institutions has influenced thus a new policy agenda, including water policy. Throughout the 1980s and 1990s, there was a growing concern that in many cases, engineering-based projects had not been wholly successful and that they had not often yielded the benefits that were expected. Increasingly, over the past decade, many programs in the water sector have begun to be primarily focused on developing institutional and human capacity rather than physical infrastructure. The result of this trend has been an attempt by those working in the sector to understand the institutional aspects related to water management.

Nowadays, water systems1 (Framing Committee 2004) are increasingly challenged by the triple threat of a changing climate, rapid population growth, and competing demands for water. Competition among agriculture, industry and cities for limited water supplies is already constraining development efforts in many countries. Demand for water is increasing in order to satisfy the needs of a growing world population, for food production, energy, industrial and domestic uses and the environment. As populations expand and economies grow, the competition for limited supplies will intensify and so conflicts among water users. The Fifth Assessment Report of the Intergovernmental Panel on Climate Change (IPCC 2014) underlines that $93 \%$ of the impacts related to climate change will be

\footnotetext{
${ }^{1}$ according to the definition given in the GWSP Science Plan.
} 
experienced in the water sector. The same report states that availability of renewable surface and groundwater resources is likely to decline significantly in most arid and semi-arid subtropical regions, aggravating competition for water between agriculture, ecosystems, industries and settlements. Climate impacts on hydrology are set to include alterations in seasonality, a rise in the frequency or intensity of extreme hydrological events (drought or flood), higher variability of precipitation patterns and increased glacial melt leading to amplification or reduction in runoff (Matthews and Le Quesne 2009; Bates et al. 2008). Moreover, a sense of lack of control is particularly pronounced in developing countries, where the capacities to understand the different issues of climate change as it affects the water systems are minimal among water managers. The limitations of the ability to control extremes by technical means have become very clear during weather extremes occurring globally over the past years. Since 1990, EM-DAT CRED estimates that climate and hydrometeorological disasters (droughts, extreme temperature, flood, mass movement of wet soil, storms, and wildfires) have cost the Latin America and the Caribbean over $\$ 200$ bn, disrupting the lives of an average of 3,6 million people annually over that period (EM-DAT 2019). Furthermore, between 1995 and 2015 the number of disasters triggered by weather-related events (drought, flood, extreme temperature, storm and mass movement - wet) is the most frequent disaster types, outnumbering all other natural disasters combined, and accounting for $90 \%$ of all-natural disasters, with the most extensive impacts on people (UNISDR and CRED 2015). Moreover, within the same period, droughts, floods and storms combined affected the most significant number of people (2300 million), resulting in total economic losses of USD722.3 billion, 72\% of the total losses (Gopalakrishnan 2013). Drought and flooding, in particular, can have devastating implications for rural populations dependent on livestock and agricultural production. Such events have triggered an increasing awareness of water managers for the possible challenges posed by global and climate change also because most recent forecasts suggest the likelihood of further worldwide increases in the intensity and frequency of water disasters in the years ahead. Therefore, the fragmented and sub-sectorial approaches are seen now as inadequate to address the increased use and abuse of freshwater systems associated with the rapid social change-taking place in most countries (Boutkan and Stikker 2004; Cleaver and Toner 2006; Cullet and Gupta 2009; Kidd 2009; McCay and Marsden 2009).

The need for coordinated management of water resources and a systemwide approach is increasingly recognized, even though it is not evident as demonstrated by the everyday practice. The traditionally centralized and technocratic approach is now considered inadequate to respond to uncertainties and extremes expected with climate change and other contextual conditions (Dominguez et al. 2011; Gersonious et al. 2012; Pahl- Wostl 2007; Truffer et al. 2007). As a result, the traditional hierarchical and technocratic focus of water management has shifted towards iterative and integrated management practices, more aligned with concepts of integrated water resources management and adaptive water management (GWP TAC 2000; Pahl-Wostl 2007). In response to nowadays challenge, water managers will need to adapt in a timely and effective manner, and in a way that builds resilience rather than degrades it. Resilience has defined by Folke et al. (2010) as "the capacity of a system to absorb disturbance and reorganize while undergoing change so as to still retain essentially the same function, structure and feedbacks, and therefore identity, that is, the capacity to change in order to maintain the same identity". In this line, adaptiveness is increasingly recognised as one of the central parameters for sustainable water 
management in rapidly changing physical and human environments (Pahl-Wostl 2007).

It is worth to note even though it is not the object of this book that implementing an adaptive water management system to adopt a more sustainable model should also envision a critical review of the water usages, in particular in those areas prone to droughts or where the water resources are already scarce being under pressure due to the global market demands.

The complexity of water management and a rise in uncertainties linked to critical drivers, actors, and boundary conditions would acquire approaches enabling management to adapt to changes in the system being managed (also see Gunderson and Holling 2001). As Biswas and Tortajada (2010, p. 130) pointed out in an insightful paper, "there have got to be radical changes in the governance processes and the institutions responsible for water to cope with the immediate challenges, potential future changes, and uncertainties both from within the sector and around the sector". This context of high uncertainty and high stakes creates significant challenges to water organisations. Thus, they are required to respond within contexts of political and economic instability and to the upheavals brought about by natural disasters, na-techs and conflicts. To achieve this, organisations require the ability to observe and analyse their environment and expand the range of response options necessary to adjust not only to changes science can predict with some degree of confidence now but also to those science has yet to identify. To do this successfully, organisations, therefore, need the capacity to reflect critically and act effectively countinuously. Reforming organisational processes is a significant and costly task for organisations concerned, and even though the author is aware of such issue, however, this is not the objective of the present research.

\subsection{Aim and Objectives}

Although research on adaptive capacity is emerging in the context of developing countries (Merz et al. 2009), most studies focus on communities or vulnerability of the physical system and seldom on the capacity of organizations which are expected to facilitate society (and environment) to adapt to the changes, such as the climate. However, understanding if organizations managing water can or cannot reduce the likely impacts and/or capitalize on the new opportunity undoubtedly becomes a paramount concern.

The main goal of this book is to investigate the process through which organizations operationalize adaptive capacity in order to implement adaptive water management to face future shocks (e.g. drought events) and stresses (environmental changes). Three broad research goals for making theoretical and methodological applicable advancements to the field of resilience studies are outlined here:

1. to characterize adaptive capacity, determining what attributes contribute most to build organisation's adaptive capacity;

2. to characterize adaptive capacity understanding the dynamics and barriers surrounding the adoption of innovative management and organisational approaches.

3. to increase understanding of the barriers to the process of implementing adaptive water governance and management;

Accomplishing these three goals will contribute to resilience thinking and sustainable science by refining and applying theory regarding the approaches that are more closely associated with higher adaptive capacity, and introduce a novel 
conceptual framework to assess organisation's adaptive capacity. Also, in this pursuit, adaptive attributes that are most relevant for organisations and favour a proactive drought risk management will be identified and analysed. Furthermore, the findings should provide important baseline information to understand barriers to implement adaptive water management and governance within the case study country.

\subsection{The structure of the book}

This book begins theoretically with a literature review focusing on the drought risk and the related impacts on the environment and society. Drought and water management are analysed to understand the interlinkages between these two management systems and how they could be integrated to respond to current and future droughts. Then, the adaptive capacity of water management organizations in enabling an adaptive water management system to face drought risk is explored, and a new conceptual framework to assess the organisation's adaptive capacity is proposed. The book is organized in four main parts: the introductory theoretical part, the methodological part, the empirical work carried out in the filed and a final reconceptualization of the problem. Those four main parts are organized in seven chapters.

Chapter 2 provides an overview of the concept of drought, its impacts on environment and society and the forms to manage and monitor droughts as well as the current and main issues and challenges related to drought risk.

Chapter 3 provides a synopsis of the current challenges of water management and highlight the need to integrate drought and water management to face current and future issues. Finally, it analyses the different classifications of the drought and water management measures, and a new categorization is proposed.

Chapter 4 positions the research in the context of existing knowledge. From this, the novelty, which this research offers as a contribution to the domains considered, is established. First, an overview of the related domains is presented. Second, these are returned to in more depth in order to communicate a landscape of the subject areas, and to tease out significant issues and to present the locus of their correspondence to this research.

Chapter 5 describes the conceptual framework developed and tested in the case study to assess the organisation's adaptive capacity.

Chapter 6 applies the main arguments from Chapter 2, 3 and 4 to critically describe the case study. In this chapter, survey data, interviews, and archival research are used to examine impacts of past droughts and recent environmental changes in the Municipality of Tomave (Potosí, Bolivia) and to investigate how water institutions face droughts, climate change and their adaptivity to such (future). Furthermore, this chapter draws on qualitative data obtained by interviews and literature review to explain why specific approaches develop (or not) to water management.

Chapter 7 aims first to provide a summary of the key insights derived as findings from the (open and semi-structured) interviews presented in the previous chapter. Data and findings from the semi-structured interviews are summarised first, and these findings are carried forward throughout this chapter. This chapter aims to revisit relevant literature to discuss the overall findings and updated conceptual framework within a contemporary context. Also presented here are the implications of the findings and limitations of the work. By means of this approach, clear contributions to knowledge this book has provided are further outlined and described. 


\section{References}

Bates BC, Kundzewiez ZW, Palutikof J P (eds) (2008) Climate change and water, Technical paper of IPCC. Geneva, IPCC Secretariat

Biswas AK, Tortajada C 2010 Future water governance: problems and perspectives. International Journal of Water Resources Development, 26(2), 129- 139

Boutkan E, Sticker A (2004) Enhanced water resources base for sustainable integrated water resources management. Natural Resources Forum 28, 2(0105)

Cleaver F, Toner, F (2006) The evolution of community water governance in Uchira, Tanzania: the implications for equality of access, sustainability and effectiveness. Natural Resources Forum 30, p 207- 218

Cullet P, Gupta, J (2009) India: evolution of water law and policy. In: Dellapenna J, Gupta, J. (eds.) The Evolution of the Law and Politics of Water, Springer Verlag, Dordrecht, p 157- 174

Dominguez D, Truffer B, Gujer W (2011) Tackling uncertainties in infrastructure sectors through strategic planning: the contribution of discursive approaches in the urban water sector. Water Policy 13:299316

Ferragina E, Marra M, Quagliarotti DAL (2002) The role of formal and informal institutions in the water sector. What are the challenges for development? Plan Bleu Regional Activity Center.

Folke C, Carpenter SR, Walker B et al (2010) Resilience thinking: integrating resilience, adaptability and transformability. Ecology and Society, 15(4): 20

Framing Committee of the GWSP ( 2004) The Global Water System Project: Science Framework and Implementation Activities, Earth System Science Partnership

Gersonius B, Nasruddin F, Ashley R et al (2012) Developing the evidence base for mainstreaming adaptation of stormwater systems to climate change. Water Research, 46(20):6824-6835

Gopalakrishnan C (2013) Water and disasters: a review and analysis of policy aspects. International Journal of Water Resources Development, 29(2):250-271 
Gunderson L, Holling CS ( 2001) Panarchy: Understanding Transformations in Human and Natural Systems. Island Press, Washington, DC(USA) GWP-TAC (Global Water Partnership-Technical Advisory Committee) (2000) Integrated water resources management, TAC Background Paper No. 4, Stockholm

IPCC (2014) Summary for policymakers. In: C.B. Field, et al., eds. Climate change 2014: impacts, adaptation, and vulnerability. Part A: Global and sectoral aspects. Contribution of Working Group II to the Fifth Assessment Report of the Intergovernmental Panel on Climate Change [online]. Cambridge: Cambridge University Press, 1- 32

Kidd M (2009). South Africa: the development of water law. In: Dellapenna J, Gupta J (eds.) The Evolution of the Law and Politics of Water. Springer Verlag, Dordrecht

Matthews J , Le Quesne T (2009) Adapting Water Management: A primer on coping with climate change. WWF-UK, Godalming, United Kingdom

McCay J , Marsden S (2009) Australia: the problem of sustainability in water. In: Dellapenna, J ., Gupta, J . (eds.) The Evolution of the Law and Politics of Water. Springer Verlag, Dordrecht

Mertz O, Halsnæes K, Olesen J E et al 2009. Adaptation to climate change in developing countries. Environ. Manage. 43:743- 752. doi:10.1007/s00267-008-9259-3

Mujumdar PP (2013) Climate Change: A Growing Challenge for Water Management in Developing Countries. Water Resources Management, 27:953-954.

Pahl-Wostl C (2007) Requirements for Adaptive Water Management. In: PahlWostl C, Kabat P, Möltgen J (eds.) Adaptive and Integrated Water Management: Coping with Complexity and Uncertainty. SpringerVerlag Truffer B, Stormer E, Maurer M et al (2010) Local strategic planningprocesses and sustainability transitions in infrastructure sectors. Environmental Policy and Governance 20(4):258-269

International Strategy for Disaster Reduction, Centre for Research On The Epidemiology of Disasters ( 2015) The Human Cost of Weather Related Disasters. ISDR and CRED, Brussels 


\section{ChAPTER 2: DeFinition(s) AND IMPACTS OF DROUght}

Abstract. This chapter provides an overview of the concept of drought, its impacts on environment and society and the forms to manage and monitor droughts as well as the current and main issues and challenges related to drought risk.

Keywords Drought, Drought risk, Impacts of drought

\subsection{DEFINITION OF DROUGHT}

Droughts rank first among all natural hazards when measured in terms of the number of affected people (Obasi 1994; Hewitt 1997; Wilhite 2000). Although as a natural hazard, droughts differ from other natural hazards in several ways (Wilhite 2000). First, drought is often referred to as a creeping phenomenon due to the fact that the onsets, as well as the end of a drought, are difficult to determine, the impacts of a drought increase slowly, often accumulate over a considerable period and may stay for years after termination. Second, in comparison to other disasters, droughts tend to affect spatially larger areas. Consequently, identification and quantification of impacts related to drought and the provision of relief are more complicated than for other natural hazards (Wilhite 2000). Third, human activities can directly trigger a drought, unlike other natural hazards, with exacerbating factors such as over farming, excessive irrigation, deforestation, overexploitation of available water, and erosion, adversely impacting the ability of the land to capture and hold water (Mishra and Singh 2010).

Thus, what drought is? A clear, universal and shared definition of what can be labelled as the drought has not been achieved yet. Drought is not aridity, a permanent climatic feature, and it is not water scarcity meaning scarcity in water availability due to physical shortage or not having access to water to ensure regular supply to meet all demands (www.unwater.org). Palmer (1965) wrote "drought means various things to various people depending on their specific interest. To farmers, drought means a shortage of moisture in the root zone of his crops. To the hydrologist, it suggests below-average levels in the streams, lakes, reservoirs, and the like. To the economist, it means a shortage which affects the stable economy". According to this, thus, drought should not be considered only as a physical phenomenon. Instead, as stated by Wilhite (2002), drought results from the interplay between a natural event and the demand placed on water supply by natural vegetation and human use.

Definitions can be divided into two classes: conceptual and operational definitions. The former state in relative terms (e.g., a drought is a long, dry period), while the latter aim to identify the onset, severity, and termination of drought periods. Some of the commonly used definitions are:

- The World Meteorological Organization (WMO 1986) defines "drought means a sustained, extended deficiency in precipitation."

- The UN Convention to Combat Drought and Desertification (UN Secretariat General 1994) defines "drought means the naturally occurring phenomenon that exists when precipitation has been significantly below normal recorded levels, causing serious hydrological imbalances that adversely affect land resource production systems."

- The Food and Agriculture Organization (FAO 1983) of the United Nations defines a drought hazard as the percentage of years when crops fail from the lack of moisture."

- The encyclopedia of climate and weather (Schneider 1996) defines a drought 
as "an extended period - a season, a year, or several years - of deficient rainfall relative to the statistical multi-year mean for a region."

- Gumbel (1963) defined a "drought as the smallest annual value of daily streamflow."

- Palmer (1965) described a "drought as a significant deviation from the normal hydrologic conditions of an area."

- Linseley et al. (1959) defined "drought as a sustained period of timewithout significant rainfall."

However, drought definitions vary, depending on the variable used to describe the drought. Hence, drought definitions can also be classified also according to other categories, which are discussed below.

\subsection{ClassificAtion OF DROUGHT}

Wilhite and Glantz (1985) categorized the definitions in terms of four basic approaches to measuring drought: meteorological, hydrological, agricultural, and socioeconomic (Figure 2.1). The first three approaches deal with ways to measure drought as a physical phenomenon. The last deals with drought in terms of supply and demand, tracking the effects of water shortfall as it ripples through socioeconomic systems. In details:

- Meteorological drought is defined as a lack of precipitation over a region for some time. Precipitation has been commonly used for meteorological drought analysis (Pinkeye 1966; Eltahir 1992). Considering drought as precipitation deficit concerning average values (Gibbs 1975), several studies have analyzed droughts using monthly precipitation data. Other approaches analyze drought duration and intensity in relation to cumulative precipitation shortages (Estrela et al. 2000).

- Hydrological drought is related to a period with an inadequate surface, and subsurface water resources for established water use of a given water resources management system. Streamflow data have been widely applied for hydrologic drought analysis (Dracup et al. 1980; Clausen and Pearson 1995). From regression analyzes relating droughts in streamflow to catchment properties, it is found that geology is one of the main factors influencing hydrological droughts (Zecharias and Brutsaert 1988; Vogel and Kroll 1992).

- Agricultural drought, usually, refers to a period with declining soil moisture and consequent crop failure without any reference to surface water resources. A decline of soil moisture depends on several factors, which affect meteorological and hydrological droughts along with differences between actual evapotranspiration and potential evapotranspiration. Plant water demand depends on prevailing weather conditions, biological characteristics of the specific plant and stage of growth, and the physical and biological properties of soil. Several drought indices, based on a combination of precipitation, temperature and soil moisture, have been derived from studying agricultural droughts.

- Socioeconomic drought is associated with failure of water resources systems to meet water demands and thus associating droughts with the supply of and demand for an economic good (water) (AMS 2004). Socio-economic drought occurs when the demand for an economic good exceeds supply as a result of a weather-related shortfall in the water supply. 


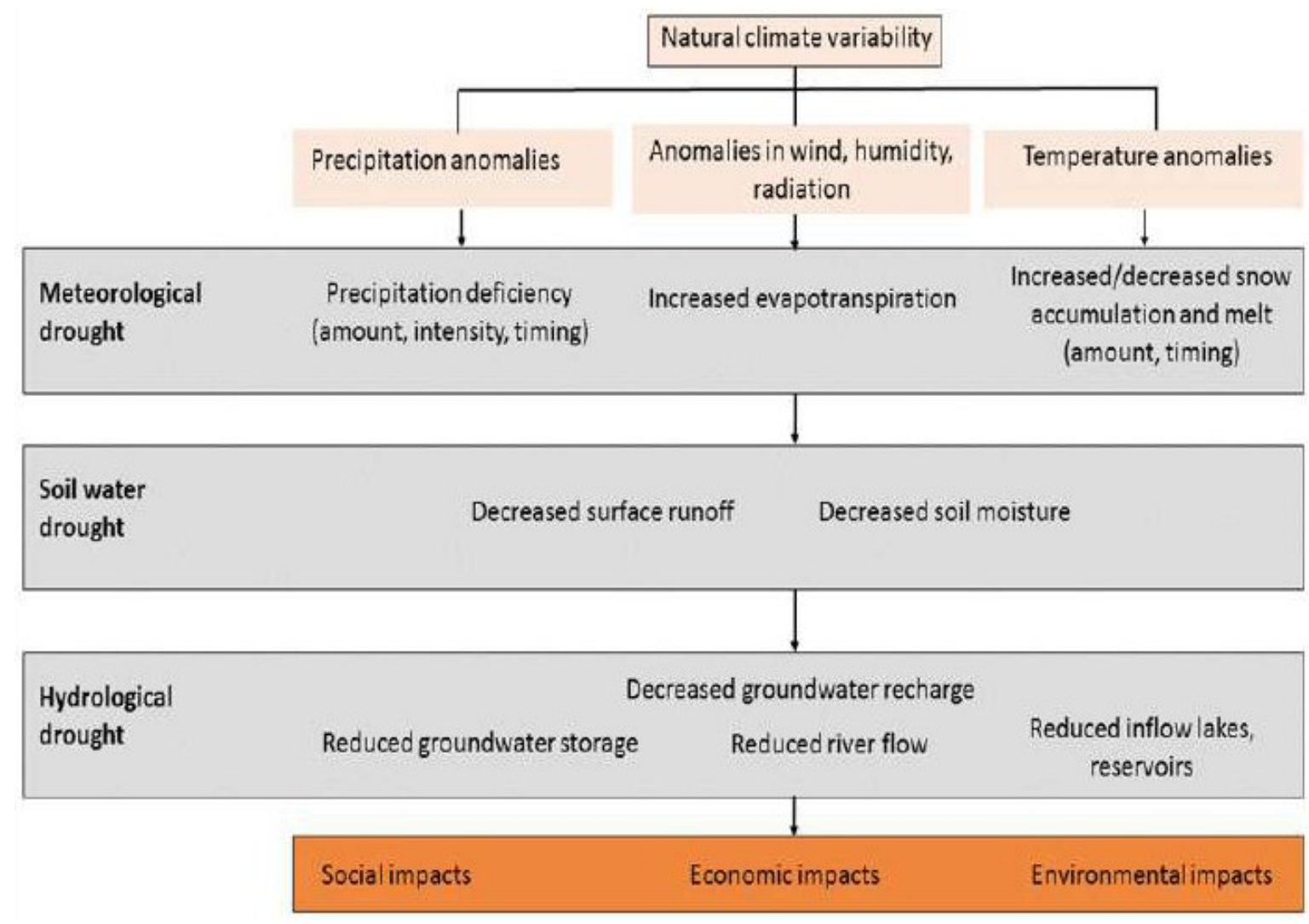

Figure 2.1: Drought types, generating processes and impacts (source: Van Loon (2015) in Poljansek et al. 2017)

\subsection{DROUGHT IN ARID AND SEMI-ARID LAND}

Drylands ${ }^{2}$ cover more than $40 \%$ of earth land surface (Oldeman et al. 1990), hosting more than 2 billion inhabitants (Millennium Ecosystem Assessment 2005). According to a ratio between precipitation (P) and potential evapotranspiration (PET), these areas can be further subdivided into hyper-arid, arid, semi-arid and dry sub-humid zones.

Such climatic zones are characterized by more frequent droughts comparing to other types of Earth lands. Moreover, such areas are under threat of desertification (Figure 2.2) excluding the hyper-arid zones mainly located in the Saharan Desert region, which have already reached the ultimate level of desertification. The probability of droughts usually increases with the rise in the ineffective rain-aridity proportion (Le Houérou 1984). Further, an increase in temperature even though not followed by a decrease in precipitation may result in enhanced land degradation and reduction of productivity in the intensely exploited lands (Emanuel et al. 1985; Manabe and Wetherald 1986). In this book hyper-arid areas (less than $100 \mathrm{~mm}$ of precipitation per year), where the vegetation is extremely scattered, are ignored; contemporaneously it focuses instead on arid (100 - $200 \mathrm{~mm})$ and semi-arid (200$400 \mathrm{~mm}$ ) zones, which, e.g. characterize the case study area in the South-West of Bolivia (Tomave municipalities).

\footnotetext{
${ }^{2}$ UNEP, Millennium Ecosystem Assessment, 2005, Drylands Systems, Chapter 22 In Ecosystems and Human Wellbeing: Current State and Trends, Volume 1, Island Press.
} 


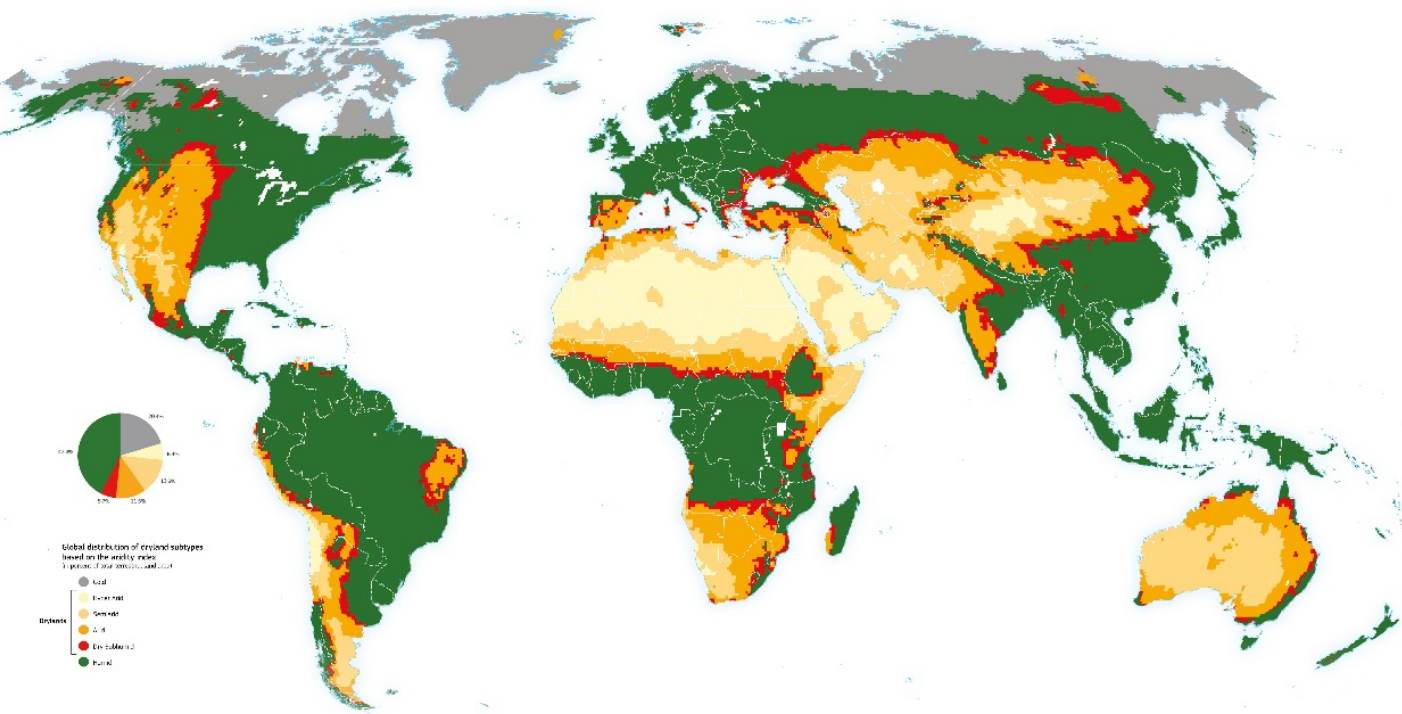

Figure 2.2: Global map of aridity. Source: Cherlet et al. 2018. Available online at https: // wad.jrc.ec.europa.eu/ patternsaridity.

\subsection{Drought impact}

Drought events can affect almost the entire components of the environmental and social-economic systems and a large variety of impacts. A drought is developing slowly, and there is often a considerable time lag before impacts not always noticeable are experienced. Such characteristics make the task of quantifying drought impacts difficult (Wilhite 2005). However, quantification is an important task, because, of all-weather extremes, drought has one of the largest impacts on society. Impacts can be classified as direct and indirect (Tallaksen and Van Lannen 2004; Meyer et al. 2013). Figure 2.3 depicts possible direct and indirect social, economic and environmental impacts.

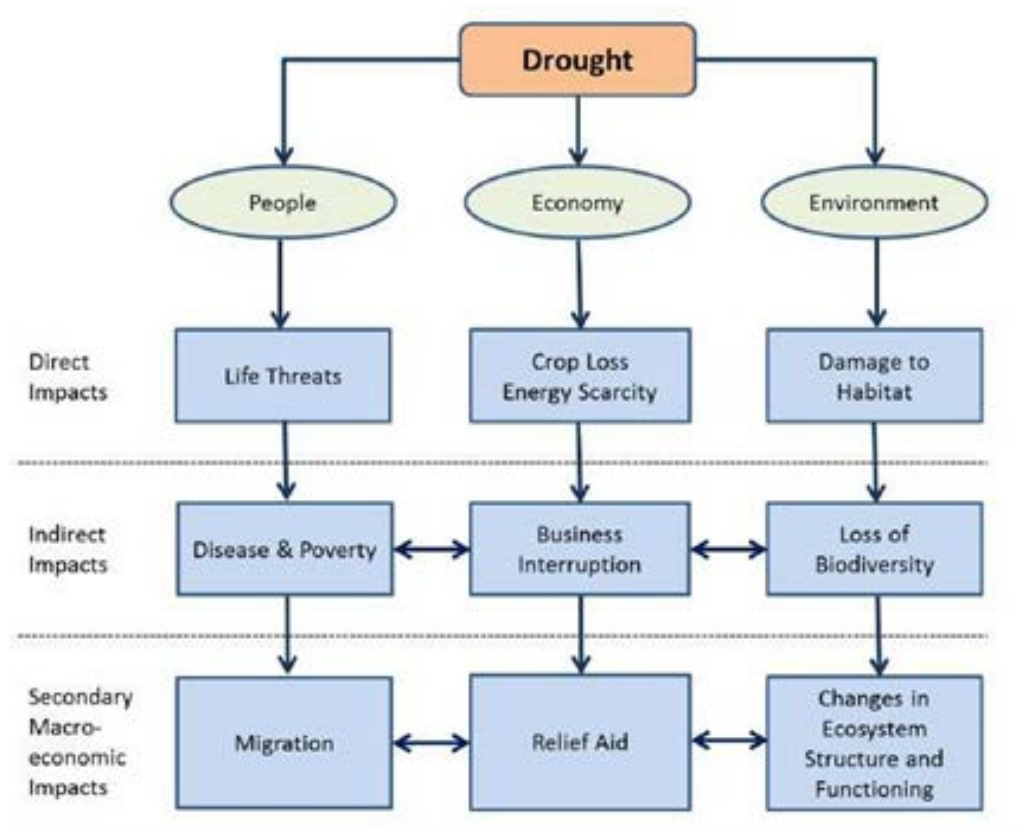

Figure 2.3: drought impacts and their interrelations (source: Poljansek et al. 2017) 


\subsubsection{Effects of droughts on the ecosystems}

The proliferation of uncovered areas (microphytic patches) during the drought has effects on an ecosystem water balance in two ways: by promoting runoff yield and by increasing evaporation. An example of the interaction between biotic and abiotic factors is the influence of drought on sand dunes and sandy landscapes. High surface temperatures during drought increase evaporation (of up to 1/3) (Gardner 1950) and inhibit germination (Neilson 1986). For sandy soils, elevated rates of erosion and/or deposition expose plant roots to high temperatures or alternatively bury the plants, resulting, in both cases, in high plant mortality (Herbel et al. 1972).

\section{Increase in surface temperature and evaporation}

Drought produces a direct increase in surface temperatures, especially of the bare areas. The outcome of the decrease of vegetation cover during the drought period is in an increase in the extent of bare areas (Balling et al. 1998). The main feature of a bare area is to have a low soil organic matter (SOM) and a low microorganism population (Borken et al. 1999). Moreover, future rainstorms characterized by intensive raindrop will have high impact in the bare areas. Consequently, storms would lead to higher surface compaction and to the formation of a physical crust (Le Houérou 1996), which, in turn, promotes runoff (Cammeraat 2004). As a result, a relatively short drought of a few years can cause extensive bare areas covered by macrobiotic crusts. These areas would be characterized by increased runoff yields and high sediment and nutrient loss during future rainstorms (Bestelmeyer et al. 2006).

\section{Wind erosion}

Wind erosion is one of the main causes of sediment and nutrient loss during and after a drought period; the reduction in vegetal cover during droughts determines an intensification of the surface wind speed (Herbel et al. 1972) and hence, increased loss of soil nutrients (West et al. 1984). A side effect which could be considered positive related with stronger winds in bare areas is the reduction in fuel load and, thus, of fire risk and/ or severity (Scholes and Archer 1997; Peters et al. 2006). However, the higher temperatures that characterize drought years could increase the risk of fires.

\section{Theimpact on fauna}

Drought has a strong impact on animals, both directly and through a reduction in plant productivity. Two effects are the most relevant. First, the diminution of aboveground phytomass affects occurring the entire food chain while a drought is occurring. Consequently, drought by impacting the vegetation affects the diversity of the fauna and its composition (Noy-Meir 1974), producing a migration of animals towards more favourable regions. Second, many animal species tend to postpone mating until the first substantial rainstorm. Besides this, many animal species are characterized by lower reproduction rate and higher mortality during droughts (Noy-Meir 1974). Moreover direct decline of the amount of food, the reduced phytomass intensifications of competition over food between faunal species. This is mainly valid for species with a selected kind of plants in their diet. 
In dry ecosystems, productivity depends on rain supply (Patten 1978), while plant communities are essentially sensitive to rain pulses (Noy-Meir 1973). Drought imposes an additional burden plant and thus, to the entire ecosystem (Rietkerk et al. 2004), and may result in a reduction of aboveground phytomass. According to Le Houérou (1996), there is a linear relationship between the number of rainy days and aridity. This is especially relevant for deserts where slight fluctuations may result in extremely dry conditions (Tevis 1958) and thus in a substantial decrease in plant productivity. Rainfall amount is the most significant productivity factor explaining over $90 \%$ of the productivity variation (Sala et al. 1988). Nonetheless, to bypass the complex relations between season, altitude and other factors influencing $\mathrm{R} / \mathrm{P}$ ratio and productivity, Beatley (1967) directly relates plant growth and soil moisture and considers the top $7.5 \mathrm{~cm}$ soil layer as the most effective layer for plant survival. Higher soil moisture content and consequent higher plant cover may thus characterize elevated areas within the same geographic zone (Shreve 1942; Svoray et al. 2004). Soil moisture also plays a cardinal role in regulating plant growth, thus following droughts seedling mortality may take place (Tielbörger and Kadmon 1995).

Plant species coping capacity to droughts

Generally, plant species have developed physiological mechanisms to cope with variability in the water supply. Annual plants balance low or even unavailability of water by inhibiting their growth until favourable moisture conditions are restored. Shrubs overcome dry conditions by reaching more moisture at greater depth. Halophyte species are able to use high soil water potential, while cyanobacteria shift into a dormant state (MacMahon and Schimpf 1981; Gutschick and Snyder 2006). Nevertheless, whether better adapted or less, drought results in a decreased aboveground phytomass.

\subsubsection{The Socio-Economic Impacts of Drought}

The direct and indirect influence of drought on humans

The social and economic effects of droughts are various and could be different according to the different development level of the country and thus to its particular level of social vulnerability. Impacts related to droughts can affect directly and indirectly human health as well through malnutrition, water-, vector- and air-borne diseases and mental aspects (WHO and WMO 2012). Most drought impacts are indirect and can propagate rapidly through the economic system with effects in regions far from the origin of the drought (Wilhite 2002).

Increasing temperatures and decreasing precipitation rates (even though not uniformly) are expected in the near future (IPCC 2014) to cause: potential losses of soil fertility (Mitchell et al. 1998); lower livestock productivity; dust storms affect air and water quality (Hagen and Woodruff 1973;), and are hazardous to aviation and traffic (Pye 1987); alterations in pest and disease risks (Bar-Ziv and Goldberg 1974), habitats changes and reduced availability of water in already water-scarce regions (Schulz and J udex 2008).

Synergistic human actions have the power to potentially increase environmental crisis, contributing to what can be seen as the socio-ecological deadline for life in dryland: landscape desertification. Furthermore, in fragile socio-ecological systems, humans command and control practices over ecological processes (Walker and Salt 2006) can negatively affect ecological processes and resilience (for instance the robustness to withstand, and the capacity to recover from, crisis). Furthermore, the reduction in the availability of some resources can lead society to increase the pressure over such resource because of autonomous unsustainable adaptations (Adger et al. 2011). Observations from dryland contexts confirm that ecological 
resilience is reduced after each severe drought, especially if drought occurs simultaneously with population growths (Mainguet and Da Silva 1998).

Agro-vulnerability to drought

The decrease of carrying capacity of grazed areas affected by droughts has as effect a reduction in the cattle productivity (Hille RisLambers et al. 2001) and thus both in a substantial decrease in cattle heads (Conley et al. 1992) and sharp economic losses of cattle owners (Conley et al. 1992). Consequently, many breeders transfer thelivestock outside the impacted zones (Gardner 1950). While drought is occurring, goats that need lower amounts of food and are better adapted to consume shrubs (Lioubimtseva et al. 2005) frequently replace the cows. Such switch to goat results in an increase of the cover of microphytic patches.

In the face of some advantages of nomadic farming during drought, the cattle farming are highly affected by drought events, especially in the arid and semiarid zones. Consequently, livestock prices rise (Fafchamps and Gavian 1997) and due to lack of natural vegetation, the emigration of farmers from the drought area (De Haan et al. 2002) is inevitable. Furthermore, if the frequency of drought is high, it can lead to the migration of entire families (Le Houérou 1996), modifying the balance of rural and urban populations, and impose drastic changes upon cities and infrastructure, as we will see in the case studies section. Moreover, droughts often result in a change in the farmed crops in favour of those demanding less water and more resilient to higher temperatures and drier conditions.

\section{References}

Adger WN, Brown K, Nelson D et al (2011) Resilience Implications of Policy Responses to Climate Change. WIREs Climate Change 2:757-766

American Meteorological Society (2004) Statement on meteorological drought. Bull Am Meteorol Soc 85:771- 773

Balling Jr RC, Klopatek J M, Hildebranndt ML et al (1998) Impacts of land degradation on historical temperature records from the Sonoran Desert. Climate Change 40:669-681

Bar-Ziv J, Goldberg GM (1974) Simple siliceous pneumoconiosis in Negev. Bedouins Arch Environ Health 29:121-126

Beatley JC (1967) Survival of winter annuals in the northern Mojave Desert. Ecology 48:745-750

Bestelmeyer BT, Brown J R, Havstad KM et al (2006) A holistic view of an arid ecosystem: A synthesis of research and its applications. In: Havstad KM, Huenneke LF, Schlesinger WH (eds) Structure and Function of a Chihuahuan Desert Ecosystem: The J ornada Basin Long-Term Ecological Research Site. Oxford University Press, NY, p 354-368

Borken W, Xu YJ, Brumme R et al. (1999) A climatic change scenario for carbon dioxide and dissolved organic carbon flux from a temperateforest soil. Soil 
Sci Soc Am J 63:1848-1855

Cammeraat ELH (2004) Scale dependent thresholds in hydrological and erosion response of a semi-arid catchment in southeast Spain Agriculture. Ecosystems and Environment 104:317-332

Cherlet M, Hutchinson C, Reynolds J et al (eds.) (2018) World Atlas of Desertification. Publication Office of the European Union, Luxembourg

Clausen B, Pearson CP (1995) Regional frequency analysis of annual maximum streamflow drought. J Hydrol 173:111- 130

Conley W, Conley MR, Karl TR ( 1992) A computational study of episodic events and historical context in long-term ecological processes: climate and grazing in the northern Chihuahuan Desert. Coenoses 7:55-60

De Haan A, Brock K, Coulibaly N ( 2002) Migration livelihood and institutions: contrasting patterns of migration in Mali. J Develop Studies 38:37-48

DracupJ A, Lee KS, Paulson EG (1980) On the statistical characteristics of drought events. Water Resour Res 16(2):289- 296

Eltahir EAB (1992) Drought frequency analysis in Central and Western Sudan. Hydrological Sci J 37(3): 185- 199

Estrela MJ , Penarrocha D, Millán M (2000) Multi-annual drought episodes in the Mediterranean (Valencia region) from 1950-1996 a spatio-temporal analysis. Int J Climatol 20:1599-1618

Fafchamps M, Gavian S (1997) The determinants of livestock prices in Niger. J African Economies 6:255-295

Food and Agriculture Organization (1983) Guidelines: Land evaluation for Rainfed Agriculture. FAO Soils Bulletin 52, Rome

Frick DM, Bode D, Salas J D ( 1990) Effect of drought on urban water supplies. I: drought analysis. J Hydrological Eng 116:733- 753

Gardner JL (1950) Effects of thirty years of protection from grazing in desert grassland. Ecology 31:44-50

Gibbs WJ (1975) Drought its definition delineation and effects. In: WMO Drought: Lectures Presented at the 26th Session of the WMO. Report No. 5. Geneva, p 3-30

Gumbel EJ (1963) Statistical forecast of droughts. Bull Int Assoc Sci Hydrol 8:523

Gutschick VP, Snyder KA (2006) Water and energy balance within the J ornada basin. In: K.M. Havstad L.F. Huenneke and W.H. Schlesinger (eds) 
Structure and Function of a Chihuahuan Desert Ecosystem: The J ornada Basin Long-Term Ecological Research Site. Oxford University Press, NY, p 176-188

Hagen LJ, Woodruff NO (1973) Air pollution from dust storms in the Great Plains. Atmos Environ 7:323-332

Herbel CH, Ares FN, Wright RA (1972) Drought effects on a semidesert grassland range. Ecology 53:1084-1093

Hewitt K (1997) Regions at Risk. A Geographical Introduction to Disasters. Addison Wesley Longman Limited, England

Hille RisLambers R, Rietkerk M, Prins HHT et al (2001) Vegetation pattern formation in semi-arid grazing systems. Ecology 82:50-61

IPCC (2014) Summary for policymakers. In: C.B. Field et al. (eds) Climate change 2014: impacts adaptation and vulnerability. Part A: Global and sectoral aspects. Contribution of Working Group II to the Fifth Assessment Report of the Intergovernmental Panel on Climate Change. Cambridge University Press, Cambridge

Le Houérou HN (1984) Rain use efficiency: a unifying concept in arid-land ecology. J Arid Environs 7:213-247

Le Houérou HN (1996) Climate change drought and desertification. J Arid Environs 34:133-185

Linsely Jr RK, Kohler MA, Paulhus J LH ( 1959) Applied Hydrology. McGraw Hill, New York

Lioubimtseva E, Cole R, Adams J M et al (2005) Impacts of climate and landcover changes in arid lands of Central Asia. J . Arid Environs. 62(2):285308

MacMahon JA, Schimpf DJ (1981) Water as a factor in the biology of North American Desert plants. In: D. D. Evans and J. L. Thames (eds) Water in Desert Ecosystems. Dowden Hutchinson and Ross, Stroudsburg

Mainguet M, Da Silva G ( 1998) Desertification and Drylands Development: What can be done? Land Degradation and Development 9:375-382

Manabe S, Wetherald RT (1986) Reduction in summer soil wetness induced by an increase in atmospheric carbon dioxide. Science 232:626-628

Millennium Ecosystem Assessment (2005) Ecosystems and human well-being: Desertification synthesis. World Resources Institute, Island Press, Washington D.C. 
Meyer V, Becker N, Markantonis V et al (2013) Assessing the costs of natural hazards - state of the art and knowledge gaps. Natural Hazards and Earth System Sciences 13(5):1351-1373

Mishra AK, Singh VP ( 2010) A review of drought concept.J ournal of Hydrology 391:202-216

Mitchell DJ, Fullen MA, Trueman IC et al (1998) Sustainability of reclaimed desertified land in Ningxia China. J. Arid Environs. 39:239-251

Mohan S, Rangacharya NCV (1991) A modified method for drought identification.Hydrological Sci. J . 36(1):11-21

Neilson RP (1986) High-resolution climatic analysis and Southwest biogeography. Science 232:27-34

Noy-Meir I (1973) Desert ecosystems: environment and producers Ann. Rev. of Ecology and Systematics 4:25-51

Obasi GOP (1994) WMO's role in the international decade for natural disaster reduction. Bulletin of the American Meteorological Society 75:1655- 1661.

Oldeman LR, Hakkeling RTA, Sombroek WG (1990) World Map of Status of Human-Induced Soil Degradation: An Explanatory Note. Wageningen: ISRIC and Nairobi UNEP, p 27

Palmer WC ( 1965) Meteorologic Drought: US Department of Commerce Weather Bureau Research Paper No. 45, p 58

Patten DT (1978) Productivity and production efficiency of an upper Sonoran Desert ephemeral community. Amer. J . Bot. 65-89

Peters DPC, Schlesinger WH, Herrick JE et al. (2006) Future directions in Jornada Research: Applying an interactive landscape model to solve problems. In: Havstad K.M. Huenneke L.F. and Schlesinger W.H. (eds) Structure and Function of a Chihuahuan Desert Ecosystem: The J ornada Basin Long-Term Ecological Research Site. Oxford University Press, NY: 369-386

Pinkeye S ( 1966) Conditional Probabilities of Occurrence of Wet and Dry Years Over a Large Continental Area Hydrol. Paper 12 Colorado State University. Fort Collins, Colorado

Poljanšek K, Marín Ferrer M, De Groeve T et al (eds). Science for disaster risk management 2017: knowing better and losing less. EUR 28034 EN Publications Office of the European Union, Luxembourg Chapter 3 Section III

Pye K (1987) Aeolian Dust and Dust Deposits. Academic Press, London 
Rietkerk M, Dekker SC, de Ruiter PC et al (2004) Self- Organized Patchiness and Catastrophic Shifts in Ecosystems. Science 305:1926- 1929

Sala OE, Parton WJ, J oyce LA et al (1988) Primary production of the central grassland region of the United States. Ecology 69:40-45

Schneider SH (ed) ( 1996) Encyclopedia of Climate and Weather. Oxford University Press, New York

Scholes RJ and Archer SR ( 1997) Tree-grass interactions in savannas Annu. Rev. Ecol. Syst. 28:517-544

Schulz O, Judex M (eds) ( 2008) IMPETUS Atlas Morocco. Research Results 2000-2007. 3. Edition Department of Geography University of Bonn, Germany

Shreve F (1942) The desert vegetation of North America. The Botanical Review 8:195-246

Svoray T, Gancharski SBY, Henkin Z et al (2004) Assessment of herbaceous plant habitats in water-constrained environments: predicting indirect effects with fuzzy logic. Ecological Modelling 180:537-556

Tallaksen LM, Van Lanen HAJ (2004) Hydrological Drought. Processes and Estimation Methods for Streamflow and Groundwater Developments in Water Science. Elsevier Science B.V., Amsterdam

Tevis J r L (1958) A population of desert ephemerals germinated by less than one inch of rain. Ecology 39:688-695.

Tielbörger K, Kadmon R (1995) Effect of shrubs on emergence survival and fecundity of four coexisting annual species in a sandy desert ecosystem. EcoScience 2:141-147.

United Nations Secretariat General (1994) United Nations Convention to Combat Drought and Desertification in Countries Experiencing Serious Droughts and/ or Desertification Particularly in Africa

Van Loon AF (2015) Hydrological drought explained. WIREs Water 2(4) 359-392.

Vogel RM, Kroll CN ( 1992) Regional geohydrologic- geomorphic relationships for the estimation of low-flow statistics. Water Resour. Res. 28(9): 24512458

Walker BH, Salt D (2006) Resilience Thinking: Sustaining Ecosystems and People in a Changing World. Island Press, Washington D.C. USA

West NF, Griffin RA, J urinak JJ (1984) Comparison of phosphorus distribution and cycling between adjacent native semidesert shrub and cultivated grass- 
dominated ecosystems. Plant and Soil 81:151-164

Wilhite DA (2002) Combating drought through preparedness. Natural Resources Forum 26(4) 275-285

Wilhite DA, Glantz M (1985) Understanding the drought phenomenon: the role of definitions. Environ. Studies 36:41-54.

Wilhite DA (2000) A methodology for drought preparedness. In Wilhite DA (ed) Drought: A Global Assessment Natural Hazards and Disasters Series. Routledge Publishers, UK

Wilhite DA, Hayes MJ, Knutson CL (2005) Drought preparedness planning: Building institutional capacity. In: Wilhite D. A. (ed.) Drought and Water Crises: Science Technology and Management Issues. CRC Press Boca Raton Florida

World Meteorological Organization (1986) Report on Drought and Countries Affected by Drought During 1974- 1985 WMO Geneva p. 118

World Health Organization, World Meteorological Organization (2012) Atlas of health and climate. World Health Organization, Geneva

Zecharias YB, Brutsaert W (1988) The influence of basin morphology on groundwater outflow. Water Resour. Res. 24(10):1645- 1650 


\title{
CHAPTER 3: WATER AND DROUGHT MANAGEMENT TODAY
}

\begin{abstract}
This chapter gives a synopsis of the current challenges of water management, and it highlights the need to integrate drought and water management to face current and future issues. Moreover, it analyses the different classifications of the drought and water management measures, and a new categorisation is proposed.
\end{abstract}

Keywords Drought risk, Climate Change, Water management, Drought management

\subsection{WHAT ARE TODAY CHALLENGES OF WATER MANAGEMENT}

Water management in a global change

Freshwater is a limited but shared resource between the environment and humans with their different uses. Regarding humans' usages, water resources management needs to address the connections between resource and service, to provide adequate water supply at the minimum cost, without endangering the environment and the future needs. This is extremely relevant because the effects of mismanagement are not straightway visible and can thus be overlooked.

With impacts on agriculture, education, energy, health, gender equity, and livelihood, water management regulates the most fundamental development challenges. Nevertheless, water management is nowadays challenged by global changes, such as population growth, urbanisation, and industrialisation, which are requiring nowadays more and more water while the over-exploitation and pollution of water resources are influencing the state of the water environment negatively. Moreover, given the inextricable connections between land use and water management, integration between water management and planning policies is hugely needed today. Therefore, water resource management system must take into account the implications of all development activities related to the environment and balance water resource management goals with long- and short-term development objectives. Water management should not be seen as a static concept, nor it should be seen as an end in itself, but rather as a tool for equitable and sustainable social and economic development. For instance, the resolution of the General Assembly of the United Nations as well as the Sustainable Development Goals (UN 2015) declaring access to water as a human right underlines the social and ethical role played by water management. Other issues, such as disparities in access to safe water, sanitation and water availability as a factor of development, are other challenges the water management has to respond to in the near future. Responding to those challenges implies the improvement of the political, social, economic and administrative systems that are in place, and which directly or indirectly affect the use, development and management of water resources and the delivery of water service delivery at different levels of society. In other words, they demand enhancement of water governance.

\section{Exposure and Vulnerability}

Another challenge refers to the rising exposure and vulnerability associated with water shortages not only during periods of peak demand because of increasing public, industrial demands but also due to the implications of the water used to produce the 
food required by the market. More sophisticated technology applied in water supply and non-structural measures on the demand side decrease our vulnerability to drought and water scarcity in some instances while increasing it in others.

At the global level, the amount of "virtual water" embodied in international food more than double in the period from 1986 to 2007 (Dalin et al. 2012). Moreover, water containing all sorts of fertilizers, pesticides, industrial waste, oils, metals and even radioactive waste, has radically compromised the ecological equilibrium of many surfaces and underground waters and they will continue to do it in other parts of the world. Furthermore, there is the issue of (legal and illegal) groundwater capitation and pollution, which is however weakly perceived, but that will show the results of a "development at all costs" model, which today needs to be thoroughly reviewed.

Drought risk and climate change

Water management has to deal with the fact that water varies in quantity and quality across the globe and through time. For instance, in semi-arid countries, such as the one analysed in this book, Bolivia, the management of scarce water resources is a significant challenge. The Millennium Ecosystem Assessment (MEA 2005) emphasised that 2 billion people living in arid, semi-arid and sub-humid regions are already today highly vulnerable to the loss of ecosystem services including water supply and that climate change is likely to increase water scarcity in these regions that are already under water stress. Concerning this, drought events can cause an intensification of the conflicts among competitive users of water in arid and semiarid countries. Besides, global changes are likely to increase the vulnerability of many regions to water scarcity and drought. In turn, drought risk is expected to increase in frequency and magnitude as a result of the expected changes in climate that could produce a change in the seasonal distribution, and in higher variability of precipitation patterns (IPCC 2014). Drought and more in general water-related disasters can cause (large) direct and indirect economic damages and losses, especially in rainfed and irrigated agriculture and in the municipal and industrial supply sector, with severe consequences on the economy, health, and social wellbeing. A clear picture of the losses resulting from drought is not available, but it can state that it follows the increasing losses trends reported by Wallemacq et al. (2018). However, such a picture is likely underestimated because of reporting methods and lack of data since most estimates of drought-related losses do not include secondary and higher-order impacts. Also, the quality of water worsens during and soon after drought episodes, due to a higher concentration of contaminants in all water bodies and to increasing seawater intrusion in coastal aquifers caused by the overexploitation of groundwater.

During a period of drought, water managers and human society have to adapt and face water scarcity. The conventional water management approaches to prepare for drought conditions have proved to be inadequate since they were established during and for a period of water abundance (Bazza 2002). Furthermore, the lack of a definition of drought together with the randomness of drought crises made organisations involved in water management less attentive to planning for drought. Besides this, the lack of information about the cost of such natural disaster coupled with the rapid decrease of publicinterests in droughts in regular precipitation periods make drought and its determination of drought losses (generally distributed over longer periods respect to other natural hazards) less urgent (Parker 2013). Therefore, now that water resources are becoming scarce and drought periods more frequent, the conventional water management approaches need to be reviewed and adapted to drought (and water scarcity) conditions as they are no longer valid. Hence, on the one hand, it is necessary to manage the water resource in a manner that takes into account the dynamic nature of social-ecological systems (SESs), the uncertainty related to 
climate change. On the other hand, the need to acknowledge the complexity of the systems to be managed and the limits in predicting and controlling them stress the necessity to adopt adaptive water management as the final goal in the development of water resources management policies.

It is worth noting that water managers should foster region-specific adaptation strategies with the local population, allowing site-specific expert knowledge to be incorporated into the planning process in order to: a. build a more participative approach; b. ensure that response strategy consider local social and political drivers. High complexity and various uncertainties characterize the relation between water management and climate change. Therefore, water-resource management should be based on a broad perspective; second, it should include interests of different sectors; and finally, it should adopt a more advanced approach to account far factors developing at different spatial and temporal scales.

Drought and climate change impacts may result in pathways to (humans) insecurity, independent of the conflict pathway (Kallis and Zografos 2014), as emphasized by Wilhite and Pulwarty (2017) and stated in a report of the US National Intelligence (NIC 2016).

\section{Water management and water organisations}

As it has been illustrated earlier in this section, the expected and current impacts of growing population, drought and climate change pose new challenges to water management and require water managers to change their perspectives on how to deal with water issues. Missing from the growing body of scholarship is an outline of water experts' unprompted priorities, in particular about pressures, challenges ad opportunities facing their organizations and communities (Baehler et al. 2018). However, adapting water organisations and their routines to cope with and face those problems is a significant challenge. Furthermore, even though improvement in technologies and changing customers' behaviours are also goals to be pursued. Technological and institutional panaceas were applied globally trying to solve water issues without critical reflection or monitoring of their appropriateness and the conditions necessary for their satisfactory performance (Pahl-Wostl 2010). Consequently, increasingly, attention is paid to the role of institutions and organizations in enabling adaptation and adaptive capacity. Several publications have recommended explicitly that institutional and organisational structures be both a focus of further research, and a priority for building adaptive capacity (Berkes 2007; Cash et al. 2006; Eakin 2005; Leary et al. 2007; Reid and Vogel 2006). However, as shown by a comprehensive study on organisations and climate change adaptation carried out for the World Bank (Agrawal 2008), little research exists on how organisations facilitate or constrain adaptive capacity in practice (Biermann 2009).

\subsection{RESPONSES TO THE CHALLENGES}

\section{Drought management}

The traditional governmental approach has been to react to drought (as well as to other natural disasters) by providing relief or emergency assistance to the affected areas. Although such a reactive approach, commonly known as the "hydro-illogical cycle" has been widely recognized as costly and ineffective, it is still widely applied (Wilhite 1993; Hamdy 2005). Moreover, it has resulted in worsening vulnerability because of self-reliance of organisations and a lack of coordination across institutions and sectors (Hayes et al. 2004). Progress on shifting the paradigm for drought management has been slow. Despite, in the last years' drought planning is moving 
from crisis management to a risk management-based approach in many countries. As noted by Verdin 2011, forensic analysis on the root causes of thelack of early action is of primary concern after the recent drought-related crises. In the European Union, the Water Framework Directive (2000/ 60/ EC) has set improvements in drought risk management as one of its seven key policy options.

Moreover, recent global initiatives and frameworks (e.g. the 2018/2019 UNCCD Drought Initiative, Sendai Framework for Disaster Risk Reduction 2015-2030, Sustainable Developments Goals, and the upcoming 2020 GAR special report on drought) have set the reduction of drought risk and its associated direct and indirect impacts as a global priority.

Several initiatives have been undertaken for establishing a common policy framework for drought management at the European and global levels. However, indeed, the High-level Meeting on National Drought Policy (HMNDP) held in Geneva in March 2013 is a turning point for drought management planning. The outputs of the HMNDP include the Policy Document recommending national drought management policy together with the final declaration and the Science Document outline the major and essential elements of a National Drought Policy. In details, (i) promoting standard and consistent approaches to vulnerability and impact assessment; (ii) developing drought monitoring and early warning systems effectively; (iii) improving preparedness, mitigation and adaptation actions and plans; (iv) putting into actions emergency response and relief measures that support land degradation and desertification and drought management policy goals. During the HMNDP, the Global Water Partnership (GWP) and the World Meteorological Organization (WMO) launched the Integrated Drought Management Programme (IDMP), which support regions and nations by providing policy and management guidance and by sharing better drought prediction tools and best practice for integrated drought management. Throughout 2013-2015, several workshops organized and held by the various partners of the IDMP resulted in the development of a ten-step process to support drought-prone countries in developing and implementing drought management policies and preparedness plans. Now, the guidelines should be used to tailoring the guidelines to the specific country needs and should not be applied uncritically.

\section{Towards integration of drought and water management}

By analysing adaptive and integrated water resources management models, it is possible to find a strong relationship with the drought preparedness since they consider various principles also required for drought preparedness. These common principles can be summarised in flexibility, participation and deliberation among stakeholders, integration within various levels of institutional and actor/ organisational networks, demand management (in equal or greater consideration as supply management). Furthermore, both models foster a shift toward a proactive approach to face unforeseen and future challenges an d encourage the use of risk-based approaches to evaluate multiple potential future droughts (hazards in general) and water management scenarios in support of decision-making. Therefore, droughts are seen not only as a disaster but as a catalyst of change. A change that under the lights of many diverse pressures and challenges to consider in water supply and demand planning and management needs to be progressively implemented at all levels. As follows, bridging drought and water management seems to be a valuable strategy to respond to failures related to separate management and with different time horizons of the same resource, water. However, there are still some open questions to be addressed. 
First, the decentralization of water resources management is essential for rapid drought monitoring and response implementation. Decentralization may produce chaos when there is no coherence between various levels (local, district, national) and no coordination between sectors.

As pointed out by Wilhite (1991), Grigg and Vlachos (1993), Fontane and Frevert (1995), a correct definition of the roles and duties of the different levels of government in planning and coordination is a primary need in the drought management process. In parallel with such explicit indication of roles, institutional flexibility should be ensured in order to maintain room for formal and informal partnership and cooperation, in particular during a possible future emergency phase. Second, water management requires management capacity, including regulatory arrangements, financial instruments, standards and plans, mechanisms for effective participation of stakeholders and knowledge and information systems. Regulations as in the case of drought mitigation, but not only, should be established as part of the planning process and kept updated every time the reference contexts change. It is reasonable to assume that drought planning would be even more effective if it is incorporated into other resource and hazard planning processes, such as land- and water-use planning, agricultural and environmental policy. The interlinkages of supply/ demand, quantity and quality of water, energy and food (feed and fibre) with droughts (and more in general, changing climate) conditions have implications for both adaptation and mitigation strategies in water management too. In the European context, theWater Framework Directive (WFD) considers droughts in different parts. It provides some criteria to consider drought impacts in the status of water bodies using additional tools to the River Basin Management Plans (RBMPs) with detailed programmes as well as plans to deal with particular aspects of water management (Water Framework Directive Article 13.5).

Nonetheless, Member States are facing some challenges in the application of these criteria; in particular, there is no a clear and standard definition of prolonged drought described in the drought management reports of the European Commission, just a general common understanding (Estrela and Vargas 2012). Besides, the relationship between RBMPs and Drought Management Plans tools is still unclear and to be defined (Estrela and Vargas 2012).

Finally, a change in available information and knowledge system would be necessary as well. The information would be provided to managers in a manner that clarifies what the uncertainties are. The information has to be framed in terms of risk to the system(s), which managers are in charge. There is a significant need for "integrated and adaptive decision support systems able to explicitly account for system uncertainty" (NRC 2005). Such systems incorporate institutional, political, and economic considerations and translate physical science findings into relevant information for specific types of decisions within specific sectors. It is important to invest in integrating prediction with institutional decision processes to provide true decision support (Parker 2013). Finally, the development and management of infrastructure for annual and multi-year flow regulation, for floods and droughts, for multi-purpose storage, and water quality and source protection are necessary. Although the construction and implementation of such monitoring systems infrastructures represent a step further to face problems related to water, they acquire relevance only once they become resources, tools for decision-makers. Monitoring systems should allow decision-makers to follow the development of drought before it becomes evident, to make the right decision regarding its onset and the type of mitigation measures to belaunched (Bazza 2002). However, because such links between monitoring systems and decision-making process are not so easy to develop, earlier agreements between institutions having different roles in the decision-making process are necessary as well as pre-established linkages between 
different levels of the indices (triggers) with drought mitigation measures. As suggested by Dziegielewski (2001), the core of a contingency plan is a determination of which drought response actions will be applied under what conditions of water shortage. Different measures can be taken before or at the beginning of drought to help reduce their impacts.

\section{Early Warning Systems}

The recent Sendai Framework for Disaster Risk Reduction (SFDRR) agreement was developed to substantially lessen global disaster mortality, the number of affected people, economic loss, and damage to critical infrastructure and disruption of essential services due to natural disasters (including droughts) by 2030. The Sendai Framework acknowledges the need for governments to have a significant role in reducing disaster risk with the support of relevant stakeholders (UN 2015). The SFDRR calls for an increase in the availability and access to disaster early warning systems. Drought early warning systems are crucial components for drought preparedness and resilience because they can deliver information to water sensitive sectors.

It is often possible to provide early warning of an emerging drought due to the characteristics of such natural hazard. Notwithstanding, a survey carried out by the ISDR Platform for the Promotion of Early Warning shows that drought early warning systems are more complicated due to different types of droughts and to the related defining parameters (Wilhite 2002) than those for other hydro-meteorological hazards and are consequently, relatively less developed globally (UNEP 2012). In addition, challenges to drought monitoring and early warning are the unceasing availability of indicators covering several hydro-meteorological components and their combined analysis into operational information for the decision-making process at different levels (van Lanen et al. 2017). In the Hyogo Framework for action 2005-2015, which is the roadmap negotiated by governments at the World Conference on Disaster Reduction in Kobe, J apan in 2005, Early Warning Systems are considered as the second priority for Disaster Risk Reduction (DRR). Drought monitoring, assessment, response, mitigation, adaptation, and early warning systems have been developed in a number of countries around the world, and some regional and continental efforts have been successful. In particular, Figure 3.1 shows the countries and/ or the regions, which have implemented a drought early warning system. 


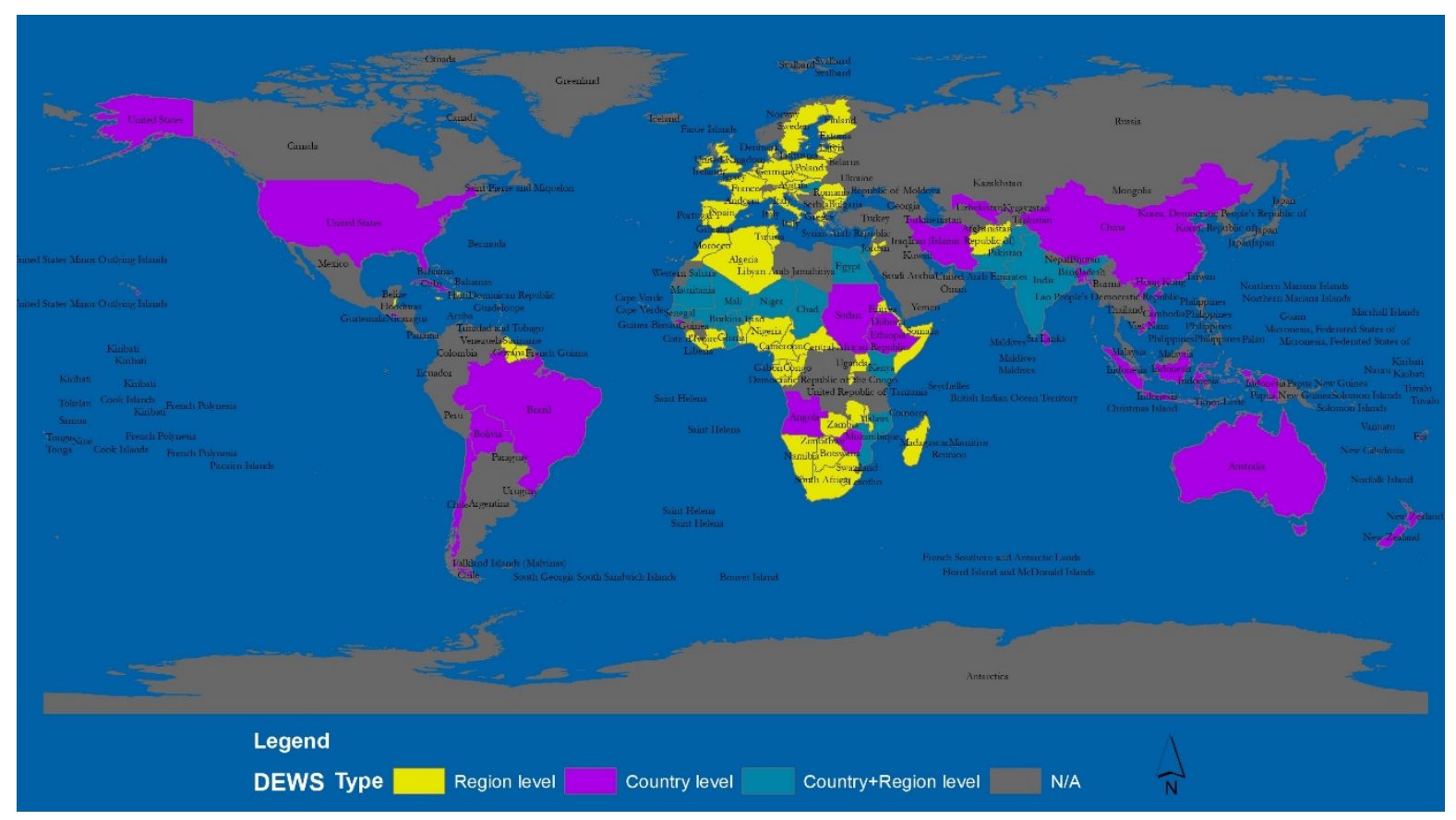

Figure 3.1: Drought early warning system per country or region (source: Author)

However, at the 2010 Global Drought Assessment Workshop in Asheville (USA) it was recognized that the creation of a Global Drought Monitoring web portal (GDMP) as a clearinghouse for global drought data and information would be precious, but neither the World Meteorological Organization nor Group on Earth Observations has the resources to provide such a program. As illustrated by the UNEP (2012) report "Early Warning Systems: A State of the Art Analysis and Future Directions", only a few Drought Early Warning Systems (DEWS) exist worldwide. Currently, three main systems operate on a global scale and provide information on major drought events. They are the Humanitarian Early Warning Service (HEWS) by the World Food Programme (WFP), the Benfield Hazard Research Center of the University College London and the Global Information and Early Warning System on Food and Agriculture (GIEWS) by FAO. The main aim of such warning tool is to provide intime relevant information regarding the emergence or probability of occurrence and the likely severity of drought to end-users and decision-makers in order to favour an effective response (UNISDR 2006; Quansah et al. 2010). Augmenting forecast and early warning information with decision-support capabilities to provide information on options for reducing vulnerability to drought enhances local coping capacities and provides an essential mechanism for reducing drought risk.

Promoting the inclusion of indigenous or local groups and knowledge in drought monitoring and early warning systems is essential for developing appropriate local drought indicators, verifying the occurrence of drought, and communicating the warnings to local populations. Furthermore, though all types of droughts are due to a precipitation deficiency, it is not sufficient to rely exclusively on this meteorological factor to evaluate drought severity and subsequent impacts. Effective DEWS must combine rainfall and other climatic parameters with water information, such as streamflow, groundwater levels, reservoir and lake levels, and soil moisture into a comprehensive assessment of present and future drought and water supply conditions. To be effective a warning should be timely and reliable (Wai Leong and $\mathrm{Wu} 2010$ ) as to allow people in charge to disseminate the warning and feel confident about it (Buchanan-Smith 2000). Although it is sure that a timely action guarantees a reduction in loss of life and property damage, false and missed alerts, have their own costs and decision-makers should be aware of this. However, a lack of awareness 
about availability and usefulness with reference to the actual formats of information provided can be seen among end-users (Kallis 2008). It is essential not to forget that the final and primary aim of an early warning system is to inform people. The design and the delivery strategy of the information should be carefully designed. Thus, the EWS process should be understood in the context of an integrated and holistic risk management framework (Asch 2009).

\section{Mitigation and response}

Several classifications of drought mitigation measures are available in the literature. Yvevjevich et al. (1983) classified the different measures distinguishing three main categories: (a) increasing water supply; (b) reducing water demand, and (c) minimizing drought impacts. Other classifications differentiate mitigation measures concerning the timing and thus in short- and long-term actions, programs, or policies implemented during or in advance of drought that reduce the degree of risk to human life, property, and productive capacity (Dziegielewski 2000).

The CONHAZ project funded by the EU 7th Framework Programme and ended up at the beginning of 2012 classified the different measures following these categories: (1) Risk management and adaptation plans; (5) Communication; (6) Monitoring and early warning; (7) Emergency response; (8) Financial incentives and; (9) risk transfer. Following the idea to link basin drought status and management actions to take, Garrote et al. (2007) developed a methodology to link operational drought indicators to policy management actions in regulated water supply systems in the Tagus River Basin Drought Management Plan in Spain.

Rossi et al. (2005) proposed a methodology to assess different measures based on their economic, environmental, and social impacts. Preferred measures are selected depending on the scores of each alternative regarding the selected criteria and the capability to reach consensus among stakeholders. In contrast to mitigation, response actions are those taken once an area is experiencing severe drought and are intended to address impacts and expedite recovery of the affected area.

Based on the classification of Yvevjevich et al. (1983) and in line with the idea to integrate drought measures and water management we propose here a classification of mitigation measures in three main categories: (1) water supply management; (2) water demand management and; (3) water allocation and planning (Table 3.1). The first category is water supply management, which aims at increasing the amount of water available to users while protecting water resources, water-dependent natural systems and interrelated habitats. This category is composed of:

- Reclamation of wastewater, which is any water that has been adversely affected in quality by anthropogenic, has two benefits. The first is a pollution abatement. The second is source substitution. Treated wastewater can be reused as drinking water, in industry, and in agriculture (as shown by J ordan and Israel) natural ecosystems (Florida's Everglades ${ }^{3}$ ).

- Rainwater harvesting refers to the direct capture of rainfall 4 . Linked to this, there are fog-harvesting techniques. Fog collection implies the collection of water from fog using fog fences, which are composed by large rectangular of canvas aiming at condensing fog into droplets of water and flow down towards a trough below the canvas ${ }^{5}$.

\footnotetext{
${ }^{3}$ See http://www.evergladesplan.org/pm/projects/proj 37 wastewater pilot.aspx

${ }^{4}$ The city of Berlin (Germany) is a relevant example of such technic; see also Schmidt et., 2007

${ }^{5}$ see: http://www.oas.org/usde/publications/Unit/oea59e/ch12.htm
} 
- Artificial recharge is the process through which the groundwater is augmented at a rate much higher than those under the natural condition of replenishment ${ }^{6}$.

- Green water indicates the precipitation on land that does not run off or recharge the groundwater but is stored in the soil or temporarily stays on top of the soil or vegetation 7 .

- Water transfers are used to shift water surpluses generated in one part of the system to another part in need of additional water supplies.

- Desalination may refer to desalination of brackish water ${ }^{8}$ as well as of seawater. It means removing some amount of salt and other minerals from saline water.

The second category concerns the water demand management, which involves the adoption of policies or investment to achieve efficient water use by all members of the community (Butler and Fayyaz 2006). This category is composed of:

- Seeking to improve irrigation efficiency targets to maximise water use, for instance, a well-known technique in the agriculture sector is the drop-by-drop system. In this system, waterfalls drop by drop just at the position of roots. Furthermore, in distribution network systems reaching an excessive percentage of water losses, leak detection and repair will permit to deliver and sell a higher amount of water produced.

- Raising public awareness of water-saving behaviour is essential in order to support conservation programmes. Public information campaigns are carried out through advertisements or target marketing 9 . Linked to this, there is the introduction of water-saving devices in households ${ }^{10}$, of which low-flush toilets and dual flush toilets are probably the most well-known devices.

- Water metering and water pricing are, for example, two economic measures that can improve water conservation and demand. A further step, it is represented by the introduction of rules that specify the minimum standards for constructed objects oriented to saving water ${ }^{11}$.

- Water restriction limits specific uses of water, for example, irrigation of lawns, car washing, filling swimming pools, or hosing down pavement areas. Water rationing determines commonly temporary suspension of water supply or a decrease of pressure below that needed for adequate supply under normal conditions. Rationing is correlated with equitable delivery of critically limited water supplies in a manner that guarantees sufficient water is supplied to preserve public health and safety (European Climate Adaptation Platform 2013) 12 .

The third category is about water allocation and planning. In details:

- Water allocation and planning focus both on future needs conditions of this resource, and on how to guarantee a sufficient amount of water for all demands.

\footnotetext{
${ }^{6}$ for further readings see: http://water.usgs.gov/ogw/artificial recharge.html

${ }^{7}$ see Hoekstra AY, Chapagain AK., Aldaya MM et al. (2011) The water footprint assessment manual: Setting the global standard. Earthscan, London, UK

${ }^{8}$ Such system is extensively used in Egypt, see Talaat et al., 2002, The potential role of brackish water desalination within the Egyptian water supply matrix. Desalination 152:375-382

${ }^{9}$ for further readings about results of public campaigns see Keeney et al., 2008, Residential water demand management: Lessons from Aurora, Colorado. Journal of the American Water Resources Association 44(1):197207

${ }^{10}$ regarding this, a really interesting project is carried out by the Singapore's national water agency, see at http://www.pub.gov.sg/conserve/Households/Pages/WaterEfficientHomesProgram.aspx

${ }^{11}$ for instance, a change in the Building code was issued in 2009 by the Department of Building Inspection of San Francisco in order to expand the water conservation requirements. see: http://www.sfdbi.org

12 see:http://climate-adapt.eea.europa.eu/viewmeasure?ace measure id=665
} 
- The environmental flow as included in "The Brisbane Declaration" (2007) ${ }^{13}$ describes the quantity, quality and timing of water flows required to sustain freshwater and estuarine ecosystems and the human livelihoods and wellbeing that depend on these ecosystems'. The definition of the environmental flow is necessary to reduce the impact of dams as well as to minimise the effect that abstractions, diversions, or additions of flow may have on rivers and streams without dams.

- In water law domain, water right refers to the right of a user to use water from a water source; therefore, the water rights trades indicates the process of selling and buying water access entitlements. Water right trade can contribute to lower the pressure on water resources in water-scarce regions, or regions with predicted degraded quality or quantity in the context of climate change (Luo et al. 2003).

- Catchment Abstraction Management Strategies permit to determine how much water is reliably available for abstraction on a catchment-by-catchment basis (Environment Agency 2013). By considering, the volume of water already licensed for abstraction and how much water the environment needs, it is possible to ascertain how much water is potentially available for further abstraction.

- Early Warning Systems (EWS) providing information on emerging dangerous circumstance are a useful tool for governments to protect the population and avoid to reduce impacts of natural disasters on infrastructure and buildings.

- Drought management plans aim to provide a management program of appropriate responses to drought conditions in the event water deliveries are reduced or curtailed to treatment plants, resulting in a reduction to water deliveries.

\begin{tabular}{|c|c|c|c|}
\hline Measures & $\begin{array}{l}\text { Water supply } \\
\text { management }\end{array}$ & $\begin{array}{l}\text { Water demand } \\
\text { management }\end{array}$ & $\begin{array}{l}\text { Water allocation } \\
\text { and planning }\end{array}$ \\
\hline Waste water re-use & $\sqrt{ }$ & & \\
\hline Rainwater harvesting & $\sqrt{ }$ & & \\
\hline Fog harvesting & V & & \\
\hline $\begin{array}{|ll|}\begin{array}{l}\text { Artificial } \\
\text { recharge }\end{array} & \text { groundwater } \\
\end{array}$ & v & & \\
\hline \begin{tabular}{|lll}
$\begin{array}{l}\text { Development } \\
\text { infrastructure }\end{array}$ & of water \\
\end{tabular} & $V$ & & \\
\hline Green water & $\sqrt{ }$ & & \\
\hline Water transfers & $\sqrt{ }$ & & \\
\hline Desalination & V & & \\
\hline Improving irrigation efficiency & & V & \\
\hline $\begin{array}{l}\text { Leakage control and reduction } \\
\text { of water distribution system }\end{array}$ & & $\sqrt{ }$ & \\
\hline $\begin{array}{l}\text { Raising public awareness for } \\
\text { water saving behavior }\end{array}$ & & $\sqrt{ }$ & \\
\hline $\begin{array}{|lrr|}\text { Introducing } & \text { water } & \text { saving } \\
\text { devices in households } & \end{array}$ & & $\sqrt{ }$ & \\
\hline \begin{tabular}{|lr}
$\begin{array}{l}\text { Economic } \\
\text { improved demand management }\end{array}$ \\
\end{tabular} & & $\sqrt{ }$ & \\
\hline $\begin{array}{l}\begin{array}{l}\text { Water saving measures in } \\
\text { building codes }\end{array} \\
\end{array}$ & & V & \\
\hline $\begin{array}{l}\text { Measures on water restrictions } \\
\text { and consumption cuts }\end{array}$ & & V & \\
\hline
\end{tabular}

${ }^{13}$ see: http://www.watercentre.org/news/declaration 


\begin{tabular}{|l|l|l|}
\hline $\begin{array}{l}\text { Determination of } \\
\text { environmental flow }\end{array}$ & & $\checkmark$ \\
\hline Water rights trade Abstraction & & $\checkmark$ \\
\hline $\begin{array}{l}\text { Catchment } \\
\text { Management Strategies }\end{array}$ & & $\checkmark$ \\
\hline $\begin{array}{l}\text { Drought management plans and } \\
\text { emergency measures }\end{array}$ & & $\checkmark$ \\
\hline $\begin{array}{l}\text { Forecasting, early warning, } \\
\text { preparedness }\end{array}$ & & $\checkmark$ \\
\hline
\end{tabular}

Table 3.1: Drought mitigation measures with reference to water management approach (source: Author)

\section{References}

Agrawal A, (2008) The Role of Local Institutions in Adaptation to Climate Change. International Forestry Resources and Institutions Program Working Paper 081-3

Asch HS, Farnandez-Steeger T, Arnhart C (2009) People centered landslide early warning systems in the context of risk management. Geographical research abstracts VO. II. EGU 2009-11466-2, Hannover, Germany, EGU General Assembly.

Baehler KJ , Biddle JC (2018) Governance for adaptive capacity and resilience in the U.S. water sector. Ecology and Society 23(4):24

Bazza M (2002) Water Resources Planning and Management for Drought Mitigation, FAO Regional Office for the Near East, Regional Workshop on Capacity Building on Drought Mitigation in the Near East, Rabat, Morocco, 1- 5 November.

Berkes F ( 2007) Understanding Uncertainty and Reducing Vulnerability: Lessons from Resilience Thinking. Natural Hazards 41:283-295

Biermann M (2009) The Role of Local NGOs in Anticipating and Responding to Climate Change. Pennsylvania State University, Department of Geography Buchanan-Smith M (2000) Role of Early Warning System in Decision-Making Process, Expert Group Meeting on Early Warning System for Drought Preparedness and Drought Management, Lisbon, Portugal, 5-7 September 2000

Butler D, Fayyaz M(eds) (2006) Water Demand Management. IWA Publishing, London

Cash DW, Adger WN, Berkes F et al (2006) Scale and Cross-Scale Dynamics: Governance and Information in a Multilevel World. Ecology and Society. $11(2): 8-19$ 
Dalin CM, Konar N, Hanasaki A et al ( 2012) Evolution of the global virtual water trade network. Proceedings of the National Academy of Sciences of the United States of America, 109: 5989-5994.

Dziegielewski B (2000) Drought preparedness and mitigation for public water supplies. In Wilhite DA (ed) Drought: a global assessment (Volume II), Hazards and Disaster Series, Routledge, London

Eakin H (2005) Institutional Change, Climate Risk, and Rural Vulnerability: Cases from Central Mexico. World Development, 33(11): 1923-1938

Estrela T, Vargas E (2012) Drought Management Plans in the European Union: The Case of Spain. Water Resour Manage 26:1537- 1553

Fontane, DG, Frevert DK (1995) Water Management under Drought Conditions: Overview of Practices. ASCE Journal of Irrigation and Drainage Engineering 12: 2

Garrote L, Martín-Carrasco F, Flores-Montoya F, Iglesias A ( 2007) Linking drought indicators to policy actions in the Tagus River drought management plan. Water Resour Manage 21(5):873- 882

Grigg NS, Vlachos EC (1993) Drought and Water-Supply Management: Roles and Responsibilities. Journal of Water Resources Planning and Management 119(5)

Hamdy A (2005) Drought Preparedness and Mitigation in the Mediterranean Region. In: Hamdy A, Lacirignola C ( 2005) Coping with Water scarsity in the Mediterranean: What, Why and How? CIHEAM, Bari, Italy

Hayes MJ , Wilhelmi OV, Knutson CL (2004) Reducing Drought Risk: Bridging Theory and Practice. Natural Hazards Review 5(2):106-113

Inderberg TH (2011) Institutional constraints to adaptive capacity: adaptability to climate change in the Norwegian electricity sector, Local Environment 16:4:303-317

IPCC, 2014: Climate Change 2014: Impacts, Adaptation, and Vulnerability. In Field CB, Barros VR, Dokken DJ et al (eds) Part A: Global and Sectoral Aspects. Contribution of Working Group II to the Fifth Assessment Report of the Intergovernmental Panel on Climate Change Cambridge. University Press, Cambridge, United Kingdom and New York, NY, USA, p 1132

Kallis G Zografos C (2014) Hydro-climatic change, conflict and security. Climate Change 123:69- 82

Kallis G (2008) Drought. Annual Review of Environment and Resources 33:85- 
118

Leary N, Adejuwon J , Barros V etal (2007) A Stitch in Time: Lessons for Climate Change Adaptation from the AIACC Project. AIACC Working Paper No. 48

Martin QW ( 1991) Drought Management plan for lower Colorado river in Texas. J Water Resour Plan Manage 117(6):645-661

Millennium Ecosystem Assessment 2005. Ecosystems and human well-being: Desertification synthesis. World Resources Institute, Island Press, Washington, D.C

National Research Council (2004) Adaptive management for water resources planning. Panel on Adaptive Management for Resource Stewardship, Committee to Assess the U. S. Army Corps of Engineers Methods of Analysis and Peer Review for Water Resources Project Planning, Water Science and Technology Board, Ocean Studies Board, Division on Earth and Life Studies. National Academies Press, Washington D. C., USA

NIC (2016) Implications for US National Security of Anticipated Climate Change.

National Intelligence Council, Washington, DC

O’Meagher B, du Pisani LG, Wilhite DH (1998) Evolution of drought policy and related science in Australia and South Africa. Agricul Sys 57(3):231-258

Ostrom E (2005) Understanding institutional diversity. Princeton University Press.

Pahl-Wostl C, Holtz G, Kastens B et al (2010) Analyzing complex water governance regimes: the Management and Transition Framework.Environmental Science and policy 13:571-581

Pirie L, de Loë RC, Kreutwiser R (2004) Drought planning and water allocation: an assessment of local capacity in Minnesota. J Environ Manage 73:25-38

Quansah JE, Engel B, Rochon GL (2010) Early Warning Systems: A Review. J ournal of Terrestrial Observation 2:2.

Reid P Vogel C (2006) Living and responding to multiple stressors in South Africa - Glimpses from KwaZulu-Natal. Global Environmental Change 16:196-206

Rossi G, Cancelliere A, Giuliano G ( 2005) Case study: multicriteria assessment of drought mitigation measures. J Water Resour Plan Manage 131(6):449- 457

UN General Assembly (2015) Transforming our world: the 2030 Agenda for 
Sustainable Development.

UNEP (2012) Early Warning Systems: A State of the Art Analysis and Future Directions. Division of Early Warning and Assessment and United Nations Environment Programme, Nairobi

UNISDR (2006) Early Warning System in the context of Disaster Risk Management. Platform for the Promotion of Early Warning, Bonn.

Van Lanen H, Vogt J, Andreu J et al (2017) Climatological risk: droughts. In: Poljanšek K, Martín Ferrer M, De Groeve T et al (eds) Science for disaster risk management 2017: knowing better and losing less. EUR 28034 EN Publications Office of the European Union, Luxembourg

Wai Leong TL, Wu G. (eds) (2010) Practices in Drought Disaster Monitoring and Early Warning, UN-ESCAP, New York

Wallemacq P, House R, McClean D (2018) Economic Losses Poverty and Disasters 1998-2017, UNISDR and CRED

Wilhite DA (1991) Drought planning: A process for state government. Water Resources Bulletin 27(1):29- 38

Wilhite DA (ed) ( 1993) Drought Assessment Management and Planning: Theory and Case Studies. Kluwer Academic Publishers, Boston

Wilhite DA ( 2002) Combating drought trought preparaness. Natural Resources Forum 26: 275-285

Wilhite DA, Pulwarty RS (2017) Drought and water crises: Lessons drawn some lessons learned and the road ahead. In Wilhite DA, Pulwarty RS (eds) Drought and Water Crises: Integrating Science Management and Policy 2nd Edition, CRC Press Taylor and Francis, p 513-525

Williamson T, Hesseln H, Johnston M (2012) Adaptive capacity deficits and adaptive capacity of economic systems in climate change vulnerability assessment. Forest Policy and Economics 15:160- 166

Yevjevich V, Da Cunha L, Vlachos E (1983). Coping with Droughts Water Resources, Publications Littleton, Colorado 


\title{
CHAPTER 4: HOW WATER MANAGEMENT AND WATER ORGANISATIONS RESPOND TO TODAY CHALLENGES?
}

\begin{abstract}
This chapter positions the research in the context of existing knowledge on water management. From this, the novelty, which this research offers as a contribution to the domains considered, is established. First, an overview of the related domains is presented. Second, these are returned to in more depth to communicate a landscape of the subject areas, to tease out significant issues and to present the locus of their correspondence to this research.
\end{abstract}

Keywords Water management, Adaptive water management, Water management organization, Adaptive capacity, Organizational adaptive capacity,

\subsection{HOW IS THE WATER PARADIGM CHANGING?}

Along with the history, different water management approaches have been applied in order to respond to the challenges of water shortage according to a shared mindset of how water management should be undertaken, codified in practice, laws, technologies, etc. In more recent years, there has been increased discussion and debate about a paradigm shift in water management (see UNESCO 2013; Younos 2011; Pahl-Wostl 2011). Today, water resources management approaches around the world are changing significantly due to a change of perspective that is currently ongoing based on insight regarding, for example, climate change uncertainty, Millennium Development Goals, and polluters pay principle.

From traditional water management to demand management

Water management has a long history, going back to the attempts in prehistoric times in response to seasonal changes in water availability. Water management played a crucial role in the transition from hunting and gathering to farming and became yet more important with the appearance of cities, industrial towns, and administrative centres. Over the centuries, indigenous and local communities developed numerous strategies to ensure the long-term sustainability of water resources, which nowadays we refer to as "traditional water management". Such methods are characterized by being socially accepted and oriented to a sustainable utilization and management of natural resources since they aim to integrate land and water management (as we will see in the Bolivian case study).

Once the technological capacities arose, however, the traditional management strategies were not considered sufficient to satisfy the increasing water demand posed by a growing population. Thus the water management approach changed toward a supply-driven water management approach. According to this approach, the water needs of communities have been seen as requirements that must be met. In this line, the water supply approach has been (and continue to be) grounded on technological progress and development of infrastructure to increase water supply. Therefore, technological efforts have been put in place to satisfy communities' water demand through the construction of significant works (structural measures), such as dams and dykes, control of water levels, and centralized top-down decision-making. The construction of all those infrastructures is aimed at guaranteeing people's access to water. However, environmental concerns about the impacts of those projects, the rising costs and the difficulties in 
coping with increasing water demand are the flip side of the coin and the reasons of the failure of this approach (Kampragou et al. 2011; White 2006; Gleick 2000). Besides, such approach would not meet those requirements defined by the introduction of the concept of sustainable water use and the related issues, such as quality management, environmental integrity, cost-effectiveness introduced in the water agenda.

Later on, the water demand management (WDM) was introduced to avoid problems related to excessive water use or at least to cap water demand (Brandes and Maas 2004). However, as argued by Brooks and Brandes (2011) WDMis subject to criticism by being grounded on an anthropocentric rather than an ecosystem perspective and focusing mainly on measures for short-term water use efficiency rather than on long-term ecological sustainability.

Along time, other several shifts (Figure 4.1) can be highlighted in water management approach due to: changes in lifestyle and people migration towards urban centres; new water uses as either new kind of use, such as recreation, or new authorization for water abstraction and use; water quality and scarcity; effects of climate change on water resources.

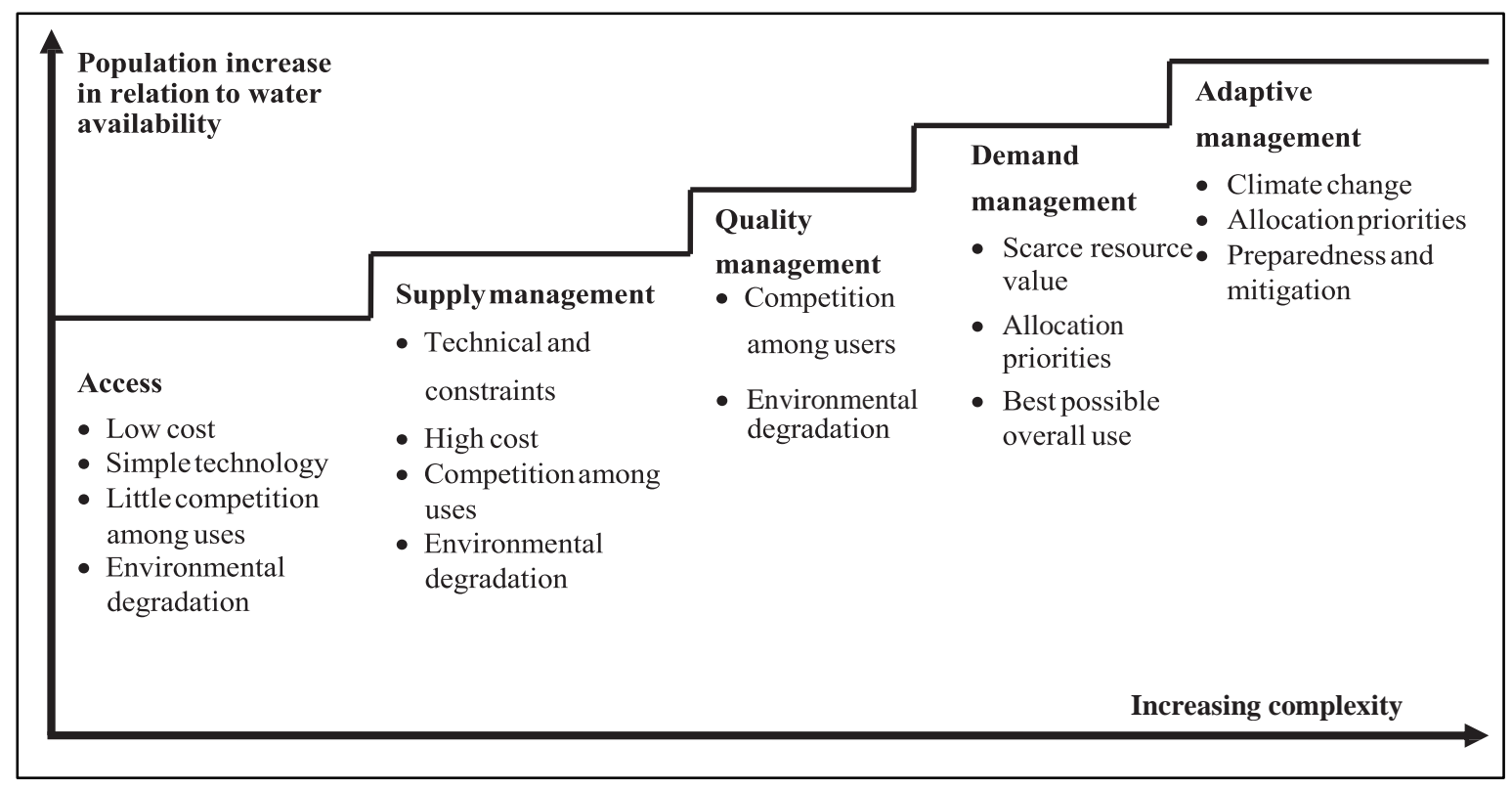

Figure 4.1: Management stages for an increasing demand - paradigm shifts (Adapted from Kampragou et al. 2011)

\section{A new water governance approach}

For a long time, the water sector has been focused on increasing water supply without posing many efforts and spending much energy to address water challenges in a governance framework explicitly. Even though technical and infrastructure development has permitted a large number of people to access water, nowadays, as discussed in the previous chapter, new challenges are posing together with the old and unsolved demands new questions. Within this context, a different form of governance is rising. It is well illustrated, for instance, by comparing one of the main conclusions of the National Science Foundation Drought Workshop held in Washington in 1990 "drought response problems are water management problems" with the outcoming conclusion of the GWP Framework for Action at the World Water Forum in The Hague in 2000, "water crisis is often a crisis of governance". As follows, the evolution in water management discourses from speaking of "government" to speaking of "governance" underline a radical change 
in thinking. Water governance is treated now as a prerequisite for managing water resources (Tropp 2007).

The Global Water Partnership's (GWP) (Rogers and Hall 2003, p.16) defines water governance as "the range of political, social, economic and administrative systems that arein place to develop and manage water resources, and the delivery of water services, at different levels of society." The World Bank broadens this definition by including the process by which those in authority are selected, monitored, and replaced, and the effectiveness of government in implementing sound policies (Jayal 1997).

When a governance system is established, a platform is built for effective water management (Hoover 2007). This platform provides managers with a set of policy objectives along with a set of essential values and decision-making processes through which to achieve the objectives (Hoover 2007). Thus, an effective governance system should enable practical water management tools to be implemented correctly (WWAP 2003). In turn, Lautze et al. (2011) help clarify the difference between governance and adaptive management by stating that water governance is the process that contributes to decision-making and it is not the outcome of decision-making. Therefore, water governance is different from water management, and it should indicate institutions what activities should be enacted by water managers.

Scott (2001), in his article "Institutions and Organizations" identifies three main typologies of institutions: regulative, normative, and cultural-cognitive. Another distinction refers to formal and informal institutions on water influence both the governance and management of water resources. Throughout the decisionmaking process, water institutions are developed and implemented to manage water resources. Institutions such as a formal legislations inform people's behaviour and affect how the decision- making and management of water resources occur. Informal institutions, such as social codes of conduct, can inform people on what is acceptable behaviour in governing and managing water resources. In a community or household setting, it is common to find informal rules that define people's behaviour and the nature of their relationships (Diaz et al. 2005). In other words, informal institutions suggest rules socially shared while formal ones indicate codes widely recognized and accepted as official (Helmke and Levitsky 2004). Helmke and Levitsky (2004) underline the connection between formal and informal institutions based on matching goals and effectiveness of formal institutions.

Della Sala (2001) suggests that the new rising form of governance advocates flexibility, which implies that informal institutions can be as important as formal ones. However, it is easy to imagine that institutional goals may be either compatible or conflicting. In the first case, formal institutions are effective, the goals fit within the formal and informal aims, and thus institutions cooperate to achieve increased efficiency and effectiveness of governance processes. In contrast to such an ideal case, formal institutions are not effective when the goals of formal and informal institutions are the antagonist. Consequently, it is more likely that the governance regime would be characterized by a higher degree of corruption; less transparent decision processes and dominated by established power structures (Pahl-Wostl 2009). It strongly contrasts with the idea of flexibility promoted by Della Sala and highlights the need to take the possible distinctions regarding the goals between formal and informal institutions into account to fully understand the nature of potential governance failures and drivers and barriers for change, identify drivers and barriers for change and the role of informality (Pahl-Wostl 2009).

Effective water governance needs to support participation in the process for deciding how water is used; foster innovation and learning among stakeholders, 
and encourage adaptation to changes in water availability (Currie-Alder et al. 2006). In water management, direct action is taken with respect to water quantity, and quality (Hoover et al. 2007; Ferragina et al. 2002) and decisions that affect society and the environment are required in a useful and timely manner (Hoover et al. 2007). Within the water sector, thereby two water management systems are emerging: (1) the integrated water management and (2) the adaptive water management. Both develop alternative forms of organisations that can work within integrated and collaborative frameworks (Tropp 2007).

\section{Towards new water resource management}

As a result of experiments done according to the leading concept related to each paradigm, numerous lessons have been learnt by water managers about the limits and opportunities of the different water management approaches in responding to change. For instance, a lesson learnt concerning water management approach that deals with different aspects of water sectorial, is that such an approach will not lead to sustainable decisions, policies and programmes. The rising awareness of the complexity of environmental issues and human-technology-environment systems has stimulated the development of new management approaches based on the insight that the systems to be managed are complex adaptive ones (Prato 2003). Within this context, both integrated water resource management and adaptive management make claims about how best to organize knowledge production for sustainability in natural resource use under conditions of complexity-IWRM focusing on integration and coordination, AM focusing on handling uncertainty (Medema et al. 2008).

\section{The Integrated Water Resource Management Approach (IWRM)}

The Integrated Water Resource Management (IWRM) as defined by the Global Water Partnership (2000) is "a process which promotes the coordinated development and management of water, land and related resources, in order to maximize the resultant economic and social welfare in an equitable manner without compromising the sustainability of vital ecosystems". IWRM can be considered the operationalization of the Dublin Principles (1992), and it is based on three pillars, which can be summarised by economic efficiency; ecological sustainability; and equity (GWP-TEC 2004).

It involves an iterative process composed of a seven-step cycle (Figure 4.2). The promotion of coordination and integration is one of the main aims of IWRM to obtain comprehensive water management and to enhance water resource sustainability (Braga 2001). Although the aim or vision of such an approach has been widely welcomed by those working in the water system, various authors have recently criticized the way it has been implemented, claiming that the IWRM approach, as defined by the Global Water Partnership, cannot be applied in practice because of operational constraints and difficulties in identifying measurable criteria of effectiveness (J effrey and Gearey 2006; Lankford and Cour 2005; Biwas 2004). Molle (2008) describes IWRM as a "Nirvana concept" because even though valuable as a policy-framing discourse, it is in practice ambiguous, complex and contradictory (Conca 2006; Biswas 2004). Consequently, on the one hand, there is a relatively low level of agreement regarding what aspects should be integrated, how, by whom; on the other hand, some scholars (Biswas 2004; Placht 2007, Watson et al. 2007) doubt that such integration can be achieved and argue that until nowits impacts on improving water management has been marginal (Biswas 2004). Moreover, the lack of an agreed definition generates ambiguity, fuzziness (van der 
Zaag 2005) creating by itself a barrier to the implementation of this approach (Medema et al. 2008). As stated by J onch- Clausen and Fugl (2001), it has become a buzzword characterized by multiple meanings.

Furthermore, the difficulties both in comparing and evaluating projects due to the lack of shared indicators (Petit and Baron 2009; Biwas 2008) and in fostering significant participation (Du Toit and Pollard 2009) have been frequently underlined by scholars.

\section{The IWRM Planning Cycle}

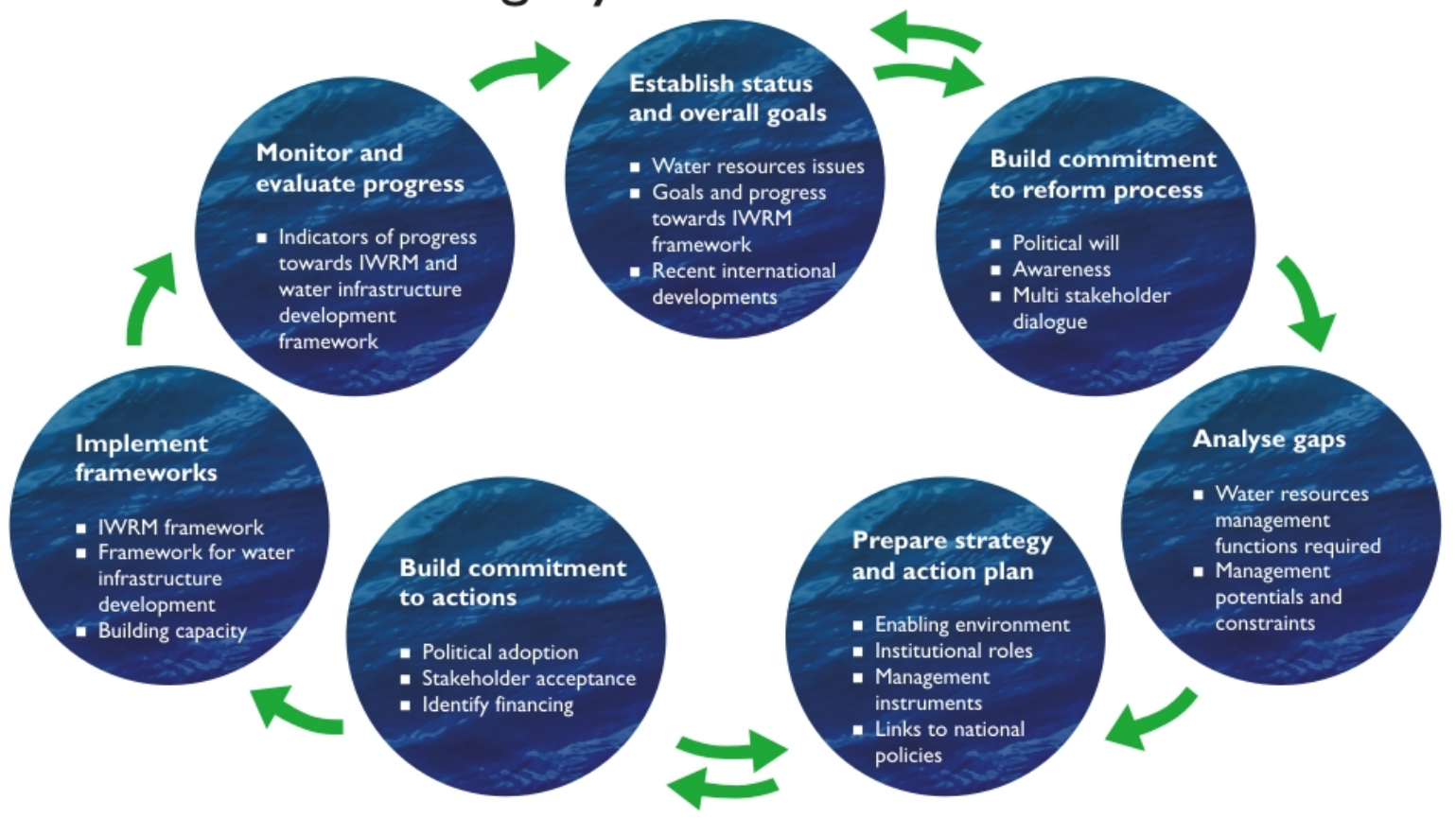

Figure 4.2: The IWRM Planning Cycle (www.gwp.org)

\section{The Adaptive Water Management (AWM)}

Although IWRM approach has been extensively recognized as valuable in identifying the principal water management issues and the related conflicting interests (Pahl-Wostl 2007a; Butterworth et al. 2010), many doubts have been raised regarding its effectiveness and feasibility (Pahl-Wostl 2007a; Biswas 2004). Consequently, more room has been dedicated to exploring more flexible approaches, such as adaptive water management.

Adaptive Management ${ }^{14}$ proposes a strategy for managing water resources through "learning to manage by managing to learn" (Bormann et al. 1999), fostering the use of planned actions as starting points for learning about systems' behaviour. The IWRM, instead, is a guiding principle for managing water resources

\footnotetext{
${ }^{14}$ The idea of adaptive management (AM) is rooted and widely discussed in ecology and specifically in the work carried out by Holling at the end of the $70 \mathrm{~s}$. The AM concept was developed at the International Institute for Applied Systems Analysis in Vienna to support the management of natural resources under uncertainty (Holling 1978; Walters 1986; Walters and Holling 1990; Prato 2003; Ohlson 1999). The adaptive concept is based on the idea of a limited capacity to predict future key drivers influencing both ecosystem and system behaviour and responses (Pahl-Wostl 2007b) and is focused on learning and identifying uncertainties (Habron 2003; Gunderson et al. 1995). Holling (1978) describes AM as an integrated, multidisciplinary and systematic approach to improve management and accommodate change by learning from the outcomes of management policies and practices'. Hence, adaptive policies are designed to test hypotheses about system response to human interventions (Lee 1993).
} 
by recognizing the variety of uses to which water is put and the diversity of benefits water brings to communities and their environments. Therefore, IWRM promotes a holistic approach to water resources management; the AWM guides the production of relevant knowledge to justify and scope intervention (Pahl-Wostl 2007).

The NeWater ${ }^{15}$ European project applied the theory of the adaptive management within the water management sector, giving a broader definition of $\mathrm{AM}$ and considering it as a guiding paradigm to design adaptive policy process (NeWater 2007). Adaptive Water Management is defined within the project as "an approach that addresses uncertainty and complexity by increasing and sustaining the capacity to learn while managing" (Mysiak et al. 2010).

As stated by Bormann et al. (1999) adaptive water management aims to interrupt the logic of the technology transfer in favour of valorisation of social learning and of knowledge sharing between managers, scientists and citizens. According to this, adaptive management is concerned with changing how responsible authorities view and undertake management actions to focus on learning as a critical way of dealing with uncertainty and promoting adaptivity (Medema et al. 2008). Hence, participation in the decision-making process is viewed by AWM as an essential prerequisite to sustainability (Sullivan 2010) as well as for enhancing the quality of choices taken at each step (Shindler and Check 1999).

Furthermore, the AWM has as a target the enhancement of the adaptive capacity of the (water) system (Pahl-Wostl 2007b), taking into account different kind of uncertainties while developing policies aimed at fostering change. In turn, recognizing the limited capacity of both predict the future and fully understand critical drivers of ecosystems, management practices are requiring to incorporate insights gained from past experiences (Pahl-Wostl 2007c). Furthermore, adaptive management is not viewed as a tool to modify the system but to learn about it. Thus, it is necessary to understand what are the vulnerabilities and what determines the ability of a water system to adapt (and to change) to tackle the issue of how to increase the adaptive capacity of the system. With reference to this, the AWM is characterized by a more flexible strategy based on feedback and adjustment, providing it with enhanced capacities.

The adaptive (water) management approach has received recognition in the academic literature for its experimental logic as a tool to support decision making in the complex natural resource management domain. However, several researchers have identified different obstacles that have prevented successful implementation and limited the realization of the benefits claimed to stem from AM (see Walters and Green 1997; Habron 2003; Levine 2004). As adaptive water management (as well as the IWRM) requires reform(s) at the governance (institutional) level as well as at the organisational process level, it is easy to believe that the implementation process of AWM will be long and hard. However, focusing just on how to change or remove those barriers still shaped by traditional "command and control" approach will not allow for a significant degree of change. Such a process of a significant transformation that is undoubtedly needed is nonetheless slow. Consequently, focusing on how to initiate a process of change at the organisational level to adopt adaptive water management can be a valid option.

\subsection{WATER ORGANISATIONS: IT IS TIME TO CHANGE}

\footnotetext{
15 The NeWater project (New Approaches to Adaptive Water Management under Uncertainty) is an Integrated Project in the 6th Framework Programme of the European Union: www.newater.uni-osnabrueck.de
} 
Organisations, together with governance, have been identified both as forces that shape adaptive capacity and as system resilience (Eakin 2005; Folke 2006; Reid and Vogel 2006). A resilience perspective in governance and decision-making, according to Carl Folke, "shifts policies from those that aspire to control change in systems...to managing the capacity of social-ecological systems to cope with, adapt to, and shape change" (2006, 254). Part of creating a resilient system is increasing the system's capacity for continuous learning, adaptation, flexibility, and collective action. The challenge here is incorporating these elements into institutions and organizations for governance and resource management (ibid.).

The implementation of a new water governance mechanism based on a nonhierarchical, polycentric, and multi-level decision-making requires the development of alternative forms of organisations able to deal with increased complexity, problems of coordination and communication posed by more horizontal decision-making processes and decentralisation. Research suggests that certain attributes and practices contribute to adaptive capacity and promote resilient systems, including flexible organisations, cross-scale interaction and knowledge sharing, and opportunities for collective and future-oriented learning (Adger et al. 2003; Agrawal 2008). Local organizations can either create an environment that enables actors to flexibly adjust to changing climatic stressors, or one that leaves actors with few options or opportunities to adapt (Eakin 2005). These organisations may be particularly well-situated to mediate between stakeholders at different scales and to channel external information and resources for adaptation (Cash et al. 2006). Furthermore, organizations can also promote collective learning that can lead to innovative ways of dealing with change (Armitage et al. 2008; Pelling et al. 2008). However, as stated in paragraph 3.1 up to now, it is not so clear how organisations build adaptive capacity in practical ways. As follows, in order to understand how adaptive capacity can be operationalized, a first question can be raised: what are the characteristics of adaptive capacity that make an organization able to choose the best fitting solution and implement it? In a "hypercompetitive" environment (D'Aveni 1994), Staber and Sydow (2001) underline how organizations tend to act in two different ways. On the one hand, organizations following a reactive approach tend to adopt a "lean and mean" strategy, focusing on their core competencies, streamlining routines, and tightening resources belts (Harrison 1994). On the other hand, organizations

may adopt an alternative strategy by developing adaptive capacity. Following this line of thought, another crucial question has to be answered: what are the inherent characteristics of an organization that make it able to develop adaptive capacity?

In the next sections, thus, the book focus first on adaptive capacity and on what adaptive capacity means both in institutions and organizations. Then, the volume will critically analyse the capacities an organisation needs to acquire in order to: identify opportunities, gather resources, capture expertise, create partnerships and opportunities for dialogue, manage and monitor the entire process between decision-making and implementation.

\subsubsection{What is adaptive capacity?}

The concept of adaptive capacity was first applied to the ecological system (Holling 1986) and analyzed within different theories (organization, resilience, governance and complexity). Then, it becomes the focus of climate change studies. More than fifteen years of studies have shown that the capacity of individuals, communities, organizations and governments to adapt to different sources of stress is a critical system characteristic. Within the SES research, such concept has been defined by 
the IPCC (2007; 2001) as: "the ability of a system to adjust to climate change (including climate variability and extremes) to moderate potential damages, to take advantage of opportunities, or to cope with the consequences". In general, the concept of adaptive capacity denotes the primary human mechanism for managing system resilience, or the "ability to recover or adjust to change through learning and flexibility so as to maintain or improve into a desirable state (Engle and Lemos 2010 , 4)." Concerning risk management and prevention, the evaluation of adaptive capacity plays a key role in supporting challenging decisions, such as where to allocate scarce resources (e.g. financial, social capital) better to face impacts of natural disasters or economic crises. While referring to the policy perspective, the decision-makers' interest is allocated in identifying and fostering specific system characteristics that (could) increase adaptive capacity.

Adaptive capacity is understood as a function of core assets from which adaptive action can emerge (Adger and Vincent 2005a). Some of these determinants are interdependent, and may vary across time, space (Smit and Wandel 2006) and scale (Posey 2009). They embody economic wealth, collective action, human and social capital, perception of risk, equity, technology, information and skills, infrastructure and institutions (Pelling and High 2005; Adger 2003; Yohe and Tol 2002; Smit et al. 2001). However, among those determinants scholars underline the decisive role played by information and knowledge, participation and representation as well as social capital, networks and resource availability in shaping a system's adaptive capacity (Eakin and Lemos 2006; Brooks and Adger 2005). Since these components refer strongly to institutional and governance mechanisms, the currently prevailing idea is that the more flexible, democratic and participatory governance is, the more adaptive capacity increases, their potential for building and/ or enhancing adaptive capacity has been extensively studied (Nelson et al. 2007).

After a decade of applied research, adaptive governance and the significance of learning mechanisms have been nowadays recognized as important tools for managing social-ecological systems during periods of rapid and unexpected change (Pahl-Wostl 2007a; Folke et al. 2005). Furthermore, some authors have observed that adaptive governance systems often self-organize as social networks, with teams and actor groups that draw on various knowledge systems and experiences for the development of shared understanding and policies (Folke et al. 2005). In the same line, the concept of adaptive co-management has been proposed for describing those flexible community-based systems of resource management tailored to specific places and situations and supported by, and working with, various organizations at different levels (Olsson et al. 2004, 77).

Mainly two different concepts - vulnerability and resilience - have been applied to assess adaptive capacity (Nelson et al. 2007; Brooks and Adger 2005; Cutter et al. 2003; Smit and Pilifosova 2003). Even though adaptive capacity is characterized by being latent and thus difficult to measure in advance, new approaches to measure and characterize it combining insights gained in analyzing both the above-mentioned concepts (Berman 2012; Engle 2011). However, a lack of consensus about the determinants of adaptive capacity is among the causes of incomparability of different case studies. Difficulties can be identified in understanding whether or not the level of current or potential adaptive capacity resulting from policy assessment is optimal and if not why (Williamson et al. 2012).

\subsubsection{Linking institutions, organisations, and adaptive capacity}

Although institutions sometimes refer to organizations (see Newman 2002) since these are formalised patterns of rules and decision-making, here they are considered as two different entities. Some researchers (Dooley 1997; Crichton et al. 
2009) have theorized organizations as complex systems characterized by interrelated agents that compose a network of connections that cooperate nonlinearly. However, organizations are here assumed as stand-in institutions embodying the nature and the processes of specific institutions.

Examining the linkages between organizations and adaptive capacity, Burnard and Bhamra (2011) refer to an organisation's inability to adapt to highimpact/low probability events because of systemic organisational weaknesses. Whereas, according to Staber and Sydow (2002), organisation's adaptive capacity means the ability to cope with unknown future circumstances. Thus, organisations will try to experience the environment actively, to apply existing and known routines (norms, ways of doing things, technologies, etc.), and to respond to a changing context reconfiguring themselves by innovating routines and articulating these in their practices.

Institutions instead refer to systems of established and prevalent social rules that structure social interaction (North 1990; Hodgson 2006), as well as to social structure composed of cultural-cognitive, normative, and regulative elements that, together with associated activities and resources, provide stability and meaning to social life (IDGEC 1999, p. 14; Scott 2001). Institutions are characterized by being inherently conservative (Gupta et al. 2008).

With reference to the new institutionalism approach, developed mostly in political sciences and sociology, the focus of analysis shifts from the architecture of institutions to how individuals operating within the context of institutional frames affect adaptive capacity through their behaviour (Hall and Taylor 1996; Nee 2005). Gupta et al. (2010) looking at what are the relations between adaptive capacity and institutions, identify adaptive capacity in the inherent characteristics of institutions. Diaz et al. (2005) state that the adaptive capacity of public institutions should be understood as the ability to pinpoint and solve problems in order to accomplish functions that facilitate the adaptive capacity of the different sectors of the civil society.

\subsubsection{How was the adaptive capacity of organisations assessed in earlier frameworks?}

The enhancement of (water) institutions' adaptive capacity can be considered instrumental in managing uncertainty to climate change, but not only related to this, and therefore to foster flexible decision-making (Tompinks and Adger 2005). As shown before, different frameworks have been developed to explore theoretical basis or to evaluate adaptive capacity. The first frameworks were focused on assessing the adaptive capacity of institutions and organizations to climate change considered as the primary driver of change. While, researches are still focused only on the organisation's adaptive capacity to climate change, there are few studies considering the role played by some other kind of drivers, such as legislative, customer behaviour, technology. Besides this, the Institutional Analysis and Development framework (IAD) developed by Elinor Ostrom (2005) provides significant insights even though not directly focused on adaptive capacity, but related more in general to rational institutional choice.

\section{Climate change as a core driver of adaptive capacity}

The Performance Acceleration Climate Tool (PACT) arose from the EU-funded EPACE Project aimed to help organisations to assess and improve their response to climate change. The tool underlines strengths and weaknesses and potential next steps for enhancing organisations' response capacity to climate change. The tool 
collects evidence across nine complementary response "pathways", and assesses each one on a scale of achievement describing hence the excellence or mediocrity of an organization sector(s) and what steps to take next.

Arnell and Delaney (2006) assess the awareness and preparedness of water utilities in England and Wales to adapt to climate change.

The EU 6th Framework project "Adaptation and Mitigation Strategies: Supporting European Climate Policy (ADAM) examined institutional adaptive management and issues of adaptive capacity, in particular, the role of institutions in supporting the implementation of measures (Lonsdale and McEvoy 2009). Furthermore, the project also investigated how information about climate change is used and turned in to activities and programmes by organizations.

The frameworks proposed by Berkhout et al. (2006) and by Pelling and High (2005, 2008) provide a more theoretical approach even though built on direct experiences. The former designs a framework to analyse which factors facilitate adaptation to climate change in organizations working in the energy and water sectors taking into account what is known about how organizations learn and how and what may hinder the learning process within an organization. The latter aims to unpack the patterns of individual and collective action within an organization that can foster or constrain organisation's adaptive capacity in the face of climate change.

Engle and Lemos (2010) analyse the characteristics of 18 Brazilian river basin councils in shaping the adaptive capacity of water systems to climate change.

Juhola and Kruse (2015) present an indicator-based framework to assess adaptive capacity of the water resources system in the Nepalese context and apply the framework to the Bagmati River Basin (BRB) in Nepal.

Mcleod et al. (2015) report how conservation organizations are progressively applying adaptive capacity assessments in respect to escalating climate change impacts.

\section{Climate change as one driver of adaptive capacity}

The method proposed by Yohe and Tol (2002) aims to assess the contributions of various adaptation alternatives to improving systems' coping capacity by focusing on the main determinants of adaptive capacity. Based on a broad definition, Yohe and Tol (2002) try to measure the adaptive capacity to a range of stresses and not only to climate change. Thus, they come up with the fact that many of the variables they assess cannot be calculated and many of the component functions can only be qualitatively defined.

The Adaptive Capacity Wheel is a method proposed by Gupta et al. (2010) to assess the inherent characteristics of institutions enabling adaptive capacity considers institutional strengths, weaknesses and opportunities for improvement. The Adaptive Capacity Wheel provides information on the ability of institutions to stimulate the adaptive capacity of society to respond to climate change and on how and if institutions need to be redesigned to foster adaptive capacity. Another approach to institutional processes, developed in political sciences and sociology, is the New Institutional Analysis (NIA). It focuses on whether the institutional cultures of organisational settings constrain actors from dealing effectively with new circumstances, or whether such organisational cultures can facilitate adaptive capacity (Matthews and Sydneysmith 2010). Thus, it provides a framework for assessing dynamic behavioural processes within organisational settings.

A more business-oriented approach has been suggested by KPMG identifying ten traits that are common in organisations that are adaptive and that the states of being, therefore, more likely to survive. Thus, the more an organization will show the attributes listed (e.g. balance of leadership and management, effective 
internal communications, robust business model, etc.) in the proposed framework the more it will be adaptive and able to embed an adaptive culture, which refers to bloom in an ever-changing environment.

\subsubsection{Analysis of organisation's adaptive capacity characteristics}

It is possible to assume that the extent to which an attribute can play a more or less crucial role to build adaptive capacity varies according to organizations' size and type. Notwithstanding, on the one hand, how and to which extent such characteristics might contribute to building the organisation's adaptive capacity are not always clearly illustrated. Besides, some authors have expressly recommended that institutional structures be both a focus of further research and a priority for building adaptive capacity (Berkes 2007; Leary et al. 2007; Reid and Vogel 2006; Cash et al. 2006; Eakin 2005). More research is needed to explore how the different attributes characterizing an organization are connected to each other, and if they are, which kind of relation (e.g. interdependency) is linking the different attributes. On the base of literature review of organisational behavioural, institutions, governance and climate change, (Engle and Lemos 2010; J ones et al. 2010; Gupta et al. 2010; Diaz et al. 2005; Staber and Sydow 2002) different indicators and criteria of organisation's adaptive capacity can beidentified as listed in Table 2 . This table shows the attributes of an organisation identified with a diverse degree of detail by different scholars. The various indicators and criteria refer to organisational capacities allowing an organization i. to pinpoint opportunities and take decisions, for instance using data and knowledge management (Yohe and Tol 2002); ii. to establish partnerships and networks to active learning processes and enhance its own capacities (Diaz and Hulber 2013; Gupta et al. 2010; Engle et al. 2010; Agrawal 2008); iii. to collect and mobilise capacities (Diaz and Hulber 2013; Gupta et al. 2010; Engle and Lemos 2010); iv. to manage and monitor the mechanisms needed to undertake actions (Berkhout et al. 2006; Gupta et al. 2010); $\mathrm{v}$. and to capture leadership qualities to lead the processes to change course or to acquire flexibility by reinforcing systems of interdependence and gaining legitimacy (Diaz and Hulber 2013; Gupta et al. 2010). Moreover, as shown in Table 4.1, some characteristics even though named differently are common to different frameworks, such as the capacity to tolerate mistake (Agrawal 2008) and ability to bend (Engle and Lemos 2010), while others are proposed by individual scholars, e.g. a clear mechanism for enforcing rules (Agrawal 2008). However, a systemic framework to assess the adaptive capacity is lacking, and most authors emphasize steps to be taken, rather than criteria to be met. Adaptive capacity is mostly seen as a "black box", the process through which adaptive capacity is operationalized is not articulated, and in general, it is described as a result of pre-existing conditions (e.g. more or less of what are declared to be its determinants). 


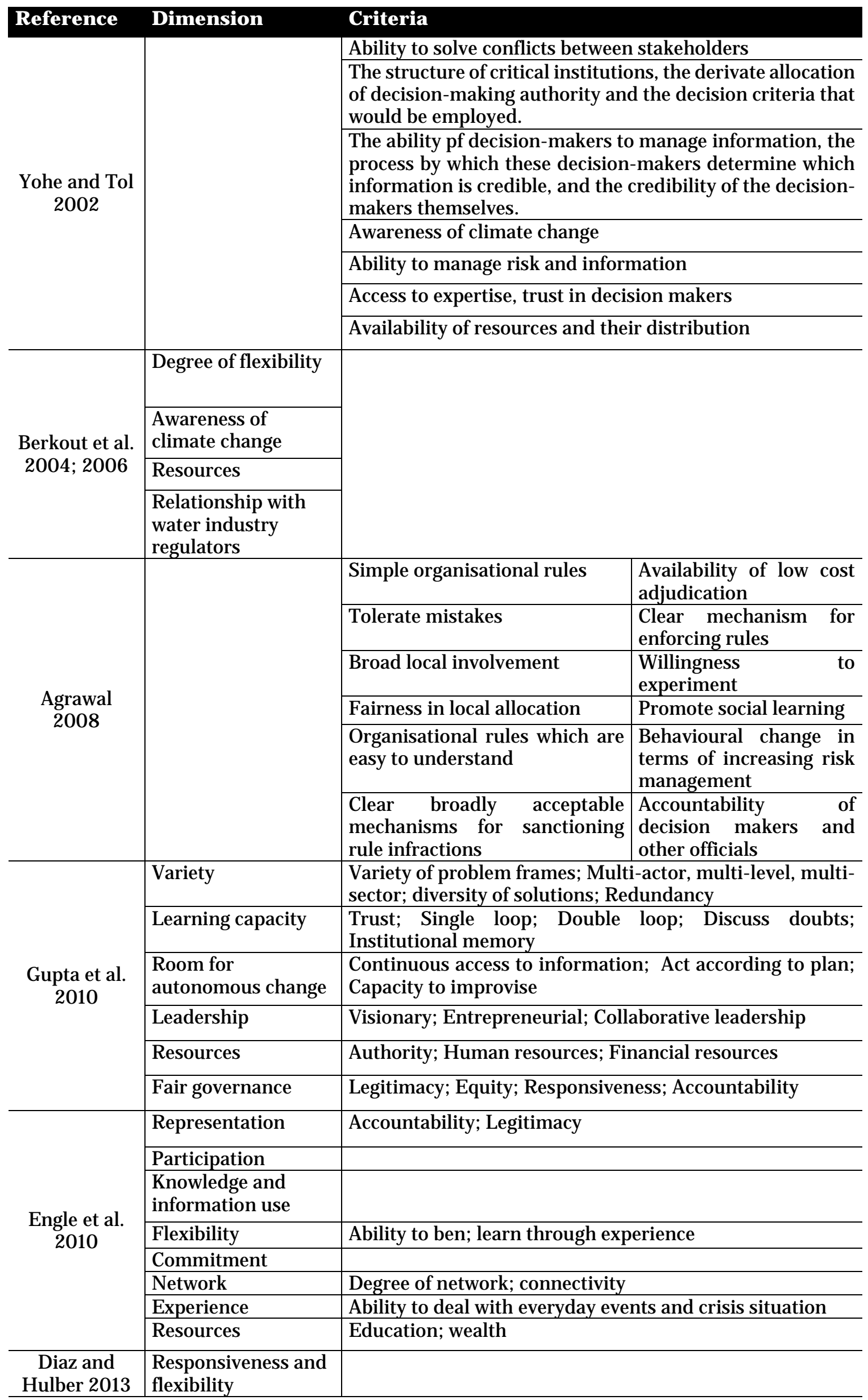




\begin{tabular}{|c|c|c|}
\hline & $\begin{array}{l}\text { Reflexivity and } \\
\text { social learning }\end{array}$ & $\begin{array}{l}\text { Preparedness to experiment; preventing rigid persistence; } \\
\text { purposefulness of practice; capacity to collect and process } \\
\text { information; vertical and horizontal coordination and } \\
\text { integration of institutions }\end{array}$ \\
\hline & $\begin{array}{l}\text { Access to } \\
\text { information }\end{array}$ & Data collection ; data management; \\
\hline & Capacity & Leadership; Resources \\
\hline & Equity & \\
\hline \multirow{4}{*}{$\begin{array}{l}\text { Ballard et al. } \\
\quad 2013\end{array}$} & Leadership & \\
\hline & $\begin{array}{l}\text { Change agents and } \\
\text { champions }\end{array}$ & \\
\hline & $\begin{array}{l}\text { Making use of } \\
\text { information about } \\
\text { potential impacts }\end{array}$ & \\
\hline & $\begin{array}{l}\text { External } \\
\text { collaboration }\end{array}$ & \\
\hline
\end{tabular}

Table 4.1: Dimensions and criteria of institutional and organisation's adaptive capacity

\section{References}

Adger WN, Brown K, Fairbrass J et al (2003) Governance for Sustainability: towards a 'thick' analysis of environmental decision-making. Environment and Planning A 35:1095-1110

Adger WN, Vincent K ( 2005a) Uncertainty in adaptive capacity. CR Geoscience 337:399- 410

Agrawal A (2008) The Role of Local Institutions in Adaptation to Climate Change. International Forestry Resources and Institutions Program Working Paper 081-3

Armitage DR, Marschke M, Plummer R (2008) Adaptive co-management and the Paradox of Learning. Global Environmental Change 18:86-98

Arnell NW, Delaney EK (2006) Adapting to climate change: public water supply in England and Wales. Climatic Change 78 (2-4):227-255

Berkes F (2007) Understanding Uncertainty and Reducing Vulnerability:

Lessons from Resilience Thinking. Natural Hazards 41:283-295

Berkhout F, Hertin J, Gann DM (2006) Learning to adapt: organisational adaptation to climate change impacts. Climatic Change 78:135-156

Berman R, Quinn C, Paavola J (2012) The role of institutions in the transformation of coping capacity to sustainable adaptive capacity Environmental Development 2:86-100

Biswas AK (2004) Integrated Water Resources Management: A Reassment Water International 29(2):248-256

Biwas AK (2008) Integrated Water Resources Management: Is It Working?

Water Resources Development 24(1):5-22 
Bormann BT, Cunningham PG, Brookes MH (1993) Adaptive ecosystem management in the Pacific Northwest U.S. Forest Service General Technical Report PNW-GTR- 341

Braga BPF (2001) Integrated urban water resources management: a challenge into the 21st century. International Journal of Water Resources Development 17(4):581- 599

Brandes O, Maas T (2004) Planning for Uncertainty. Municipal World Magazine. Brooks DB, Brandes O (2011) Why a Water Soft Path Why Now and What Then? J ournal of Water Resources Development 27(2):315-344

Brooks N, Adger WN (2005) Assessing and enhancing adaptive capacity. In: Lim B, Spanger-Siegfried E (eds) Adaptation Policy Frameworks for Climate Change: Developing Strategies Policies and Measures. UNDP- GEF.

Burnard K, Bhamra R (2011) Organisational resilience: development of a conceptual framework for organisational responses. International J ournal of Production Research 49(18):5581-5599

Butterworth J, Warner J, Moriarty P et al (2010) Finding practical approaches to Integrated Water Resources Management. Water Alternatives 3(1):6881

Cash DW, Adger WN, Berkes F et al (2006) Scale and Cross-Scale Dynamics: Governance and Information in a Multilevel World. Ecology and Society $11(2): 8-19$

Conca K (2006) Governing Water: Contentions Transnational Politics and Global Institution Building. Cambridge MA MIT Press

Crichton MT, Ramsay CG, Kelly T (2009) Enhancing organisational resilience through emergency planning: learnings from cross-sectoral lessons. J ournal of Contingencies and Crisis Management 17(1):24- 37

Currie-Alder B, Thompson L, Bustamante R (2006) Insights on Water Governance: Research in the Middle East/North Africa and Latin America. Presented at Survival of the Commons. Mounting Challenges and New Realities the Eleventh Conference of the International Association for the Study of Common Property, Bali Indonesia, 19-23 J une2006

Cutter SL, Boruff BJ Shirley WL (2003) Social vulnerability toenvironmental hazards. Social Science Quarterly 84(2)242-261

D’Aveni RA ( 1994) Hypercompetition: Managing the Dynamics of Strategic Maneuvering. Free Press, New York 
Della Sala V (2001) Constitutionalising Governance: Democratic Dead End or Dead on Democracy Constitutionalism Web-Papers ConWEB 6/2001. http://les1.man.ac.uk/ conweb

Diaz HP, Hulbert M (2013) The Need for Adaptive Water Governance: Lessons from Canada and Chile. In Knieling Jörg; Leal Filho Walter (eds) Climate Change Governance. Springer, Heidelberg, p 171-184

Diaz H, Rojas A, Richer L et al (2005) Institutions and Adaptive Capacity to Climate Change. IACC Working Paper 9. Retrived from http:/ / citeseerx.ist.psu.edu/viewdoc/ versions?doi=10.1.1.514.3262 Access 10 March 2020

Dooley KJ (1997) A complex adaptive systems model of organization changes. Nonlinear Dynamics Psychol Life Sci 1(1):69- 97

Du Toit D, Pollard S (2009) Updating public participation in IWRM: a proposal for a focused and structured engagement with catchment management strategies. Water SA 34(6):707-714

Eakin H, Lemos MC (2006) Adaptation and the state: Latin America and the challenge of capacity-building under globalization. Global Environmental Change-Human and Policy Dimensions 16(1)

Eakin H (2005) Institutional Change Climate Risk and Rural Vulnerability: Cases from Central Mexico. World Development 33(11):1923-1938

Engle NL (2011) Adaptive capacity and its assessment Special Issue on The Politics and Policy of Carbon Capture and Storage. Global Environmental Change 2(2):647- 656

Engle NL, Lemos MC ( 2010) Unpacking governance: Building adaptive capacity to climate change of river basin in Brazil. Global Environmental Change 20:4-13

Ferragina E, Marra M, Quagliarotti DAL (2002) The role of formal and informal institutions in the water sector. What are the challenges for development? Plan Bleu Regional Activity Center

Folke C (2006) Resilience: The emergence of a perspective for social- ecological systems analyses. Global Environmental Change 16 (3): 253-267

Folke C, Hahn T, Olsson P et al (2005) Adaptive governance of social-ecological systems. Annual Review of Environment and Resources 30:1:441- 473

Gleick PH (2000) The Changing Water Paradigm. A Look at Twenty-first Century Water Resources Development Water International 25(1):127-138 Gunderson LH, Holling CS, Light SS (1995) Barriers and Bridges to the Renewal 
of Ecosystems and Institution. Columbia University Press, New York

Gupta J , Termeer C, Klostermann J et al (2010) The Adaptive Capacity Wheel: a method to assess the inherent characteristics of institutions to enable the adaptive capacity of society. Environmental Science \& Policy 13(6):459-471

Gupta J, Termeer K, Klostermann J et al (2008) Institutions for Climate Change: A Method to assess the Inherent Characteristics of Institutions to enable the Adaptive Capacity of Society. Institute for Environmental Studies (IVM), The Netherlands, Amsterdam

Global Water Partnership (2000) Integrated Water Resources Management. TAC Background Papers No.4. Global Water Partnership

Global Water Partnership - Technical Advisory Committee (2004) Integrated Water Resources Management (IWRM) and Water Efficiency Plans by 2005. Why What and How? TEC Background Papers No. 10. Global Water Partnership - GWP, Stockholm, Sweden

Habron G (2003) Role of Adaptive Management in Watershed Councils. Environmental Management 31:29-41

Hall P, Taylor RCR (1996) Political science and the 3 new institutionalisms.

MPIFG Discussion Paper 96/6. Max Planck-Institut für Gesellschaftsforschung, Germany, Köln

Harrison B (1994) Lean and mean: The changing landscape of corporatepower in the age of flexibility. Basic Books, New York

Helmke G, Levitsky S (2004) Informal institutions and comparative politics: a research agenda. Perspect Polit 4:725-740

Hodgson GM (2006) What Are Institutions? J ournal of Economic Issues XL(1) Holling CS (1978) Adaptive Environmental Assessment and Management. J ohn Wiley and Sons, Chichester, England

Holling CS (1986) The resilience of terrestrial ecosystems; local surprise and global change. In: Clark WC, Munn RE (eds) Sustainable Development of the Biosphere. Cambridge University Press, Cambridge UK, p 292-317

Hoover G, Howatson A, Churchill J etal (2007) Navigating the Shoals: Assessing Water Governance and Management in Canada, The Conference Board of Canada, Ottawa, Ontario

IDGEC Scientific Planning Committee (1999) Institutional Dimensions of Global Environmental Change. IHDP Report 9, Bonn 
IPCC (2007) Climate Change 2007: The Physical Science Basis. In: Solomon S,

Qin D, Manning M et al.(eds) Contribution of Working Group I to the Fourth Assessment Report of the Intergovernmental Panel on Climate Change. Cambridge University Press, Cambridge, United Kingdom and New York, NY, USA, p 996

IPCC ( 2001) Working Group II Climate Change 2001: Impacts Adaptation and Vulnerability. Cambridge University Press

Jayal NG (1997) The Governance Agenda: Making Democratic Development Dispensable. Economic and Political Weekly 32(8):407-412

J effrey P, Gearey M ( 2006) Integrated water resources management: Lost on the road from ambition to realisation? Water Science and Technology 53(1):1-8

J onch-Clausen T, Fugl J (2001) Firming up the conceptual basis of integrated water resources management. International J ournal of Water Resources Development 17:501-510

J uhola S, Kruse S (2015) A framework for analysing regional adaptive capacity assessments: challenges for methodology and policy making. Mitig. Adapt. Strategies Glob. Change 20:99-120

Kampragou E, Lekkas DF, Assimacopoulos D (2011) Water demand management: implementation principles and indicative case studies. Water and Environment J ournal

Lankford BA, Cour. J (2005) From Integrated to Adaptive: A New Framework for Water Resources Management of River Basins. Proceedings of the East Africa River Basin Management Conference, Morogoro, Tanzania, 7-9 March 2005

Lautze J, de Silva S, Giordano M et al (2001) Putting the Cart before the Horse: Water Governance and IWRM. Natural Resources Forum 35:1, p 1-8

Leary N. Adejuwon J, Barros V et al (2007) A Stitch in Time: Lessons for Climate Change Adaptation from theAIACCProject. AIACCWorking Paper 48

Lee KN (1993) Greed Scale Mismatch and Learning. Ecological Applications 3(4):560-564

Levine J (2004) Adaptive management in river restoration: theory vs. practice in western North America. Water Resources Center Archives: Restoration of rivers and Streams. University of California Multi- Campus Research, Unit Berkley 
Lonsdale K, McEvoy D (2009) Final report D-A1.4b: Final report on policy analysis and adaptive capacity, EU ADAM project

Matthews R, Sydneysmith R (2010) Adaptive Capacity as a Dynamic Institutional Process: Conceptual Perspectives and their Application. In: Armitage D. Plummer R. (eds) Adaptive Capacity: Building Environmental Governance in an Age of Uncertainty. Springer, Heildelberg

Mcleod E, Szuster B, Hinkel J (2015) Conservation Organizations Need to Consider Adaptive Capacity: Why Local Input Matters. Conservation Letters 9(5):351-360

Medema W, McIntosh BS, J effrey PJ (2008) From premise to practice: a critical assessment of integrated water resources management and adaptive management approaches in the water sector. Ecology and Society 13(2):29

Molle F (2008) Nirvana concepts narratives and policy models: Insight from the water sector. Water Alternatives 1(1):131- 156

Mysiak J, Henrikson HJ, Sullivan C et al (2010) The adaptive water resource management handbook. Earthscans, London, UK

Nee V (2005) A new institutional approach to economic sociology. In: Smelser N, Swedberg R (eds.) The Handbook of Economic Sociology 2nd edn. Princeton University Press, $\mathrm{p}$ 49- 74

Nelson DR, Adger WN, Brown K ( 2007) Adaptation to environmental change: contributions of a resilience framework. Annual Review of Environment and Resources 32:395- 419

Newman J (2002) The new public management modernization and institutional change: Disruptions disjunctures and dilemmas. In McLaughlin $\mathrm{K}$, Osborne SP, Ferlie E (eds) New public management: Current trends and future prospects. Routledge, London, $\mathrm{p}$ 77-92

North DC (1990) Institutions Institutional Change and Economic Performance Cambridge University Press Cambridge

Olsson P, Folke C, Berkes F (2004) Adaptive Co-Management for Building Resilience in Social-Ecological Systems. Environmental Management 34:75-90

Ostrom E (2005) Understanding institutional diversity. Princeton University Press.

Pahl-Wostl C (2007a) Requirements for Adaptive Water Management. In: PahlWostl C, Kabat P, Möltgen J (eds) Adaptive and Integrated Water Management. Coping with Complexity and Uncertainty. Springer, Verlag 
Pahl-Wostl C (2007b) Transition towars adaptive management of water facing climate change and global change. Water Resources Management 21: 4962

Pahl-Wostl C, Sendzimir J, J effrey P et al (2007c) Managing change toward adaptive water management through social learning. Ecology and Society 12(2):30

Pahl-Wostl C (2009) A conceptual framework for analysing adaptive capacity and multi-level learning processes in resource governance regimes. Global Environmental Change 19(3):354-365

Pahl-Wostl C, J effrey P, Isendahl N et al (2011) Maturing the New Water Management Paradigm: Progressing from Aspiration to Practice. Water Resour Manage 25:837- 856

Pelling M, High C ( 2005) Understanding adaptation: what social capital offer assessments of adaptive capacity. Global Environmental Change 15: 308319

Pelling M, High C, Dearing J et al (2008) Shadow spaces for social learning: a relational understanding of adaptive capacity to climate change within organisations. Environment and Planning A 40(4):867- 884

Petit O, Baron C (2009) Integrated Water Resources Management: From general principles to its implementation by the state. The case of Burkina Faso. Natural Resources Forum. 33(1):49-59

Placht M (2007) Integrated water resource management: Incorporating integration equity and efficiency to achieve sustainability. International Development Environment and Sustainability 3:3

Posey J (2009) The determinants of vulnerability and adaptive capacity at the municipal level: evidence from floodplain management programs in the United States. Global Environmental Change 19:482- 493

Prato T (2003) Adaptive Management of large rivers with special reference to the Missouri River J ournal of the American. Water Resources Association 39(4):935-946

Reid P, Vogel C (2006) Living and responding to multiple stressors in South Africa-Glimpses from KwaZulu-Natal. In: Global Environmental Change 16:196-206

Rogers P, Hall A (2003) Effective Water Governance. Global Water Partnership Technical Committee Background Paper no.7 
Scott RW (2001) Institutions and Organizations 2nd ed. Sage Publications Thousand, Oaks

Shindler B, Cheek KA ( 1999) Integrating citizens in adaptive management: a propositional analysis. Conservation Ecology 3(9) http:// www.ecologyandsociety.org/vol3/iss1/art9.

Smit B, Wandel J (2006) Adaptation adaptive capacity and vulnerability. Global Environmental Change 16(3):282-292

Smit B, Pilifosova O (2003) From adaptation to adaptive capacity and vulnerability reduction. In: Smith JB, Klein RJT, Huq S (eds) Climate Change Adaptive Capacity and Development. Imperial College Press, London

Smit B, Pilifosova O, Burton I et al (2001) Adaptation to climate change in the context of sustainable development and equity. In Climate Change 2001: Impacts Adaptation and Vulnerability. Contribution of Working Group II to the Third Assessment Report of the Intergovernmental Panel on Climate Change JJ, McCarthy O, Canziani F et al (eds), Cambridge University Press, Cambridge UK

Staber U, Sydow J (2002) Organisational adaptive capacity: A Structuration Perspective. J ournal of Management Inquiry 11(4):408-424

Sullivan CA (2010) Challenges of river basin management. In: Mysiak J, Henrikson HJ, Sullivan C et al (eds) The Adaptive Water Resource Management Handbook, Earthscan, London

Tompkins EL, Adger WN (2005) Defining response capacity to enhance climate change policy. Environmental Science and Policy 8:562-571

Tropp H (2007) Water Governance: trends and needs for new capacity development.Water Policy 9 Supplement 2:19-30

Unesco (2013) Beyond 2015 - A Paradigm Shift in Water Management to Realise the Future We Want for All. J AK/2013/ PI/H/ 11 J akarta. UNESCO Office J akarta

Van der Zaag P (2005) Integrated water resources management: relevant concept or irrelevant buzzword? A capacity building and research agenda for Southern Africa. Physics and Chemistry of the Earth 30:867-871

Walters CJ, Green R ( 1997) Valuation of Experimental Management Options for Ecological Systems. Journal of Wildlife Management 61:987-1006

Watson N, Walker G, Medd W (2007) Critical perspectives on integrated 
water management. The Geographical J ournal 173(4):297-299

White GF ( 2006) Foreword. In: Duane D, Baumann J, Boland J et al Urban Water Demand Management and Planning. MoGraw-Hill Inc, NewYork Williamson T, Hesseln H, J ohnston M (2012) Adaptive capacity deficits and adaptive capacity of economic systems in climate change vulnerability assessment. Forest Policy and Economics 15:160- 166

Walters CJ (1986) Adaptive management of renewable resources. MacMillan Pub. Co, NewYork

Walters CJ, Holling CS (1990) Large-scale Management Experiments and Learning by Doing. Ecology 71:2060-2068

World Water Assessment Programme (2003) The 1st UN World Water Development Report Water for People Water for Life: Chapter 15

Yohe G, Tol RSJ ( 2002) Indicators for social and economic coping capacity moving toward a working definition of adaptive capacity. Global Environmental Change-Human and Policy Dimensions 12(1):25-40

Younos T (2011) Paradigm shift: Holistic approach for water management in urban environments. Frontiers of Earth Science 5(4):421-427 


\title{
CHAPTER 5: REACT, a New Conceptual Framework for Assessing Organisation's adaptive capacity
}

\begin{abstract}
This chapter identifies and investigates through a critical review of the relevant literature the characteristics of the adaptive capacity regarding organisations and institutions. Through such characteristics, the work proposes a conceptual framework to assess organisation's adaptive capacity, named REACT.
\end{abstract}

Keywords Assessment of adaptive capacity, Organisational adaptive capacity, Water management organisation, Operationalizing adaptive capacity of an organisation

\subsection{REACT}

Making a case for expanding organisation's adaptive capacity and improving upon previous assessment efforts by bringing together insights from business, organisational behaviour, organisational resilience and climate change context, a conceptual framework, named REACT, to assess the adaptive capacity of organizations and understand how adaptive capacity can be operationalized has been developed. Based on the characteristics identified in the literature, it can be stated that within an organization not all attributes are equally strategic (playing the same role) and they are not all used contemporaneously by an organization to accomplish a goal. According to this, REACT clusters the various dimensions and criteria in two categories: the "REACT-Process" and the "REACT-Capacities", which respectively refer to the problem management phasis and to the capacities to run organisational routines.

\section{The REACT-Process}

The term "process" is used to refer to the operational concept that enables an analyst to point out the structure applied by an organisation to deal with issues, seek for solutions, implement solutions and monitor the effectiveness of applied actions. Problems can present different characteristics. They could be at different and multiple levels, such as decision, management and operational stage. The process uses a set of four dimensions to describe the process, which works as a cycleand includes (1) problem finding, (2) problem shaping, (3) problem solving, and (4) decision taking (Figure 5.1). 


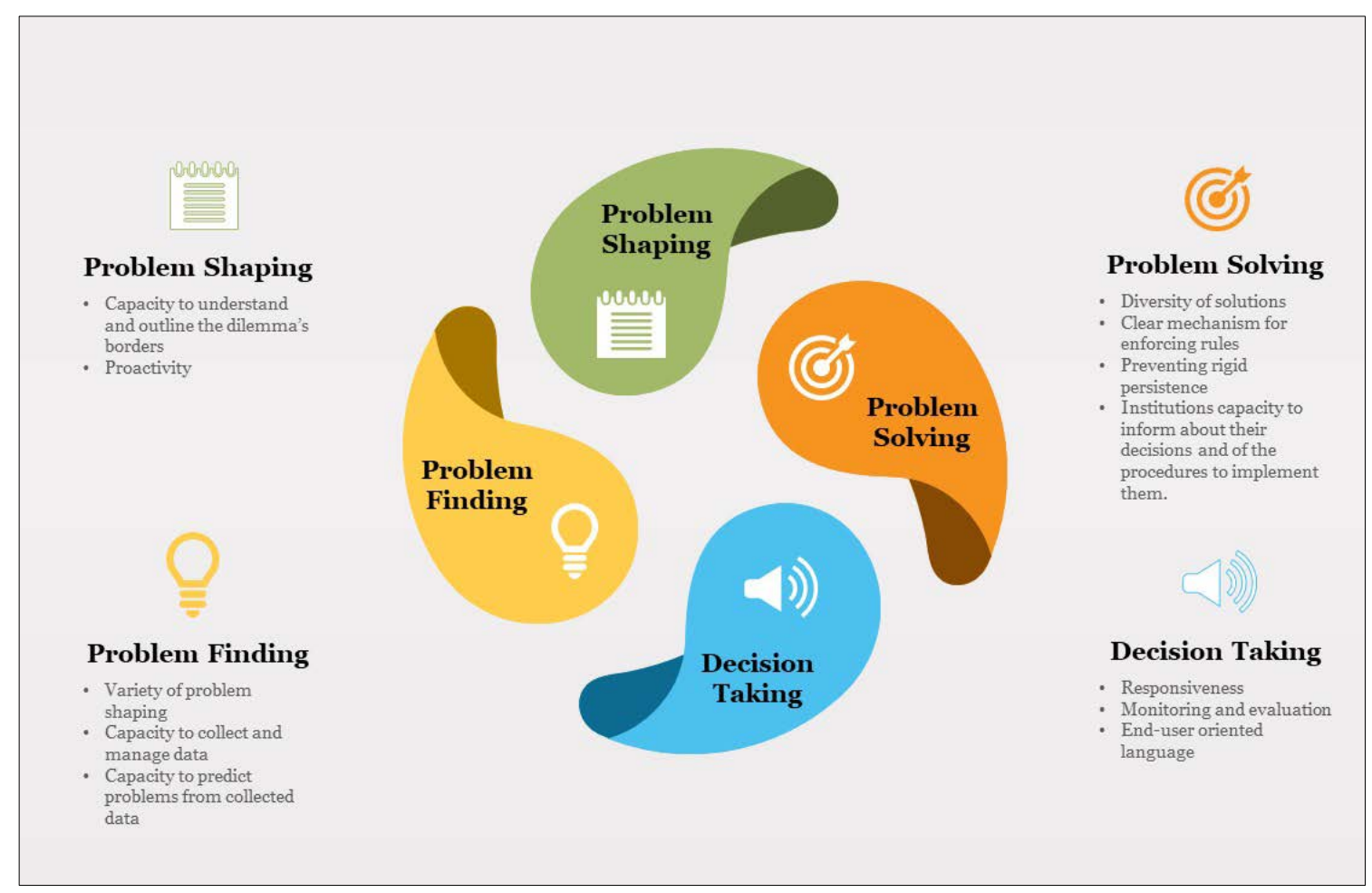

Figure 5.1: the "Process" and the working mechanism

The first dimension, "problem finding", indicates, on the one hand, the capacity of an organisation to use a variety of problem frames. Within an organisation, "variety" could concern dynamic capabilities (Collins 1994) as processes of search of alternative ways to respond to different situations, changing and adapting its routines (Cyert and March 1963). Gupta et al. (2010) underline how "variety" entails that there are no single applicable frameworks as well as there is no single best policy or strategy, but that there are many. Staber and Sydow (2002) mention variety in terms of "multiplexity" pointing out how sharing information within a system may bring in diverse knowledge enhancing thus the organisational system's flexibility in responding to demands arising from the environment. Likewise, Engle and Lemos (2010) state that interactions and negotiations at all levels between institutions and stakeholders by increasing the variety of perspectives does not only enhance their adaptive capacity but permit even to consider diverse interests like those of non-human and future-generations.

Further, Diaz and Hubert (2013) recognised the need to change the traditional approach of the public sector to an environmental problem to address climate change challenges and suggest integrating non-public actors in the process, avoiding thus strategies, conditions and norms dictated by the state. In line with, "variety" is here understood as the capacity to view a situation through a different layer, reformulating problems from other angles, and the ability to change the paradigm of reference.

On the other hand, the "problem finding" clusters together with the capacity to collect data to provide information regarding a specific topic and the capacity to predict problems based on the collected data, being sensitive to perceive a plight (even using weak signals).

The "problem shaping" phase aims to assess the organisational capacity to process data following two criteria: (a) the capacity to understand and outline the border of the dilemma to solve, because recognising the existence of a problem is not enough to change the situation. Thus it is necessary to define and describe the puzzle and provide information in a manner that allows managers to shape policy without limiting their ability in designing solutions to the dilemma; (b) how procedures 
(reactive or proactive mode) are initiated to work it out. The second criteria also concern with the capacity of an organisation to open communications with all stakeholders to build consensus between all interested parties and establish a shared vision that serves everyone.

The third dimension refers to "problem-solving". Problem-solving should not refer only to the capacity of developing appropriate, innovative solutions, but also to the ability to make decisions under uncertainty and choose reversible options. In other words, the idea is to favour strategies that are reversible and flexible over irreversible decisions (Smith 1997, Hallagate 2009). Besides, in this phase, it is crucial to develop shared solutions to avoid barriers, to disseminate and communicate the decisions taken, and to choosethrough a participatory process the enforcing rules as simple as possible, but as complex as necessary.

The last step of the process is "decision-taking". It aims to assess (1) organisations' capacity in evaluating and monitoring the implementation and success of the applied solutions; (2) responsiveness, (e.g. the capacity to be receptive to feedback and to respond to). Thus, an organisation's adaptive capacity is assessed according to the four different dimensions, and within each dimension, it is further assessed according to the different criteria.

\section{The REACT-Capacities}

The category of "Capacities" identifies those attributes acting as a framework, which supports and allows organisations to operate and face different issues during the day-to-day activities as well as during the emergence phases. An organisation uses specific inherent characteristics to carry out an activity according to the stages of the process earlier described. As shown in Table 5.1, the different attributes illustrated in the reviewed literature and listed in the right column of the table have been framed in agreement with the five identified dimensions (left column of the table): (1) learning capacity (of organisation structures); (2) individual learning capacity; (3) sharing and negotiating; (4) leadership; (5) capacity.

These five dimensions have been selected for two main reasons.

First, because the co-existence of these five pillars creates the conditions to develop a cycling learning and evaluative process, allowing an organisation to adopt different configurations and adapt its decision-making procedures to changing circumstances.

Second, because of their capacity to embed direct and indirect correlations between the different inherent characteristics, such as self-organisation (individual learning capacity) and leadership, generating tensions within the same organisation.

The successive paragraphs analyse the different dimensions and criteria to understand their role in enabling or not the adaptive capacity of an organisation.

\begin{tabular}{|c|c|c|c|}
\hline Dimensions & Attributes & Description & $\begin{array}{l}\text { Relation to } \\
\text { Literature }\end{array}$ \\
\hline \multirow{3}{*}{$\begin{array}{c}\text { LEARNING } \\
\text { CAPACITY } \\
\text { (organizational) }\end{array}$} & $\begin{array}{l}\text { Ability to deal } \\
\text { with everyday } \\
\text { situation }\end{array}$ & $\begin{array}{l}\text { It underlines the capacity of an organization to deal } \\
\text { with uncertainties and surprises, to think on the base } \\
\text { of possible scenarios, and the availability of an } \\
\text { emergency plan to follow as references. }\end{array}$ & $\begin{array}{l}\text { Engle and Lemos, } \\
2010 .\end{array}$ \\
\hline & $\begin{array}{l}\text { Ability to deal } \\
\text { with crisis } \\
\text { situation }\end{array}$ & $\begin{array}{l}\text { it refers to the ability to take the risk of making } \\
\text { mistakes }\end{array}$ & $\begin{array}{l}\text { Cohen and Levithal } \\
\text { 1990; Leonard- } \\
\text { Barton, 1992; Staber } \\
\text { ans Sydow, 2002. }\end{array}$ \\
\hline & $\begin{array}{l}\text { Willingness to } \\
\text { experiment }\end{array}$ & $\begin{array}{l}\text { it concerns the ability of an organization to learn } \\
\text { through the evaluation of policy experiences and } \\
\text { enhance the abilities converting weaknesses into }\end{array}$ & Goodin, 1996. \\
\hline
\end{tabular}




\begin{tabular}{|c|c|c|c|}
\hline & & opportunity & \\
\hline & $\begin{array}{l}\text { Institutional } \\
\text { memory }\end{array}$ & $\begin{array}{l}\text { It concerns the ability of an organization to learn } \\
\text { through the evaluation of policy experiences and } \\
\text { enhance the abilities converting weaknesses into } \\
\text { opportunity. }\end{array}$ & $\begin{array}{l}\text { Ostrom 2005; Gupta } \\
\text { et al., } 2010 .\end{array}$ \\
\hline & $\begin{array}{l}\text { Single-, } \\
\text { double-, and } \\
\text { triple loop }\end{array}$ & $\begin{array}{l}\text { It refers to the capacity to learn and thus to reform } \\
\text { routines by enhancing them or by changing its core } \\
\text { values }\end{array}$ & $\begin{array}{l}\text { Argyris and Schon, } \\
\text { 1978; Hargrove, } \\
\text { 2002; Folke et al. } \\
\text { 2005; Marshall and } \\
\text { Marshall, 2007; } \\
\text { Brockhaus et al., } \\
\text { 2012; Westlng et al., } \\
\text { 2014. }\end{array}$ \\
\hline & Trust & $\begin{array}{l}\text { It is the capacity to develop ties based on trust both } \\
\text { between individuals and groups within an } \\
\text { organization, and between an organization and its } \\
\text { stakeholders. }\end{array}$ & $\begin{array}{l}\text { Pelling and High, } \\
\text { 2005; Gupta et al., } \\
2010 .\end{array}$ \\
\hline \multirow{3}{*}{$\begin{array}{l}\text { LEARNING } \\
\text { CAPACITY } \\
\text { (individual) }\end{array}$} & $\begin{array}{l}\text { Willingness to } \\
\text { change and to } \\
\text { adapt }\end{array}$ & $\begin{array}{l}\text { It refers to the capacity to embrace change and take } \\
\text { personal action to prevent problems }\end{array}$ & $\begin{array}{l}\text { Pelling and High } \\
\text { 2005; Agrawal et al., } \\
\text { 2008; Otto- } \\
\text { Banaszak et al. } \\
2011 .\end{array}$ \\
\hline & $\begin{array}{l}\text { Preparedness to } \\
\text { experiment }\end{array}$ & $\begin{array}{l}\text { It is related to the capacity to increase the individual } \\
\text { capacity to self-organize and innovate fostering } \\
\text { social capital }\end{array}$ & $\begin{array}{l}\text { Lim et al., 2005, } \\
\text { Brockhaus et al., } \\
2012 .\end{array}$ \\
\hline & $\begin{array}{l}\text { Continuous } \\
\text { access to } \\
\text { information }\end{array}$ & $\begin{array}{l}\text { It concerns the existence of a solid and updated } \\
\text { accumulation of information }\end{array}$ & $\begin{array}{l}\text { Gupta et al., 2010; } \\
\text { Inderberg, 2011; } \\
\text { Williamson et al., } \\
2012 .\end{array}$ \\
\hline \multirow{5}{*}{$\begin{array}{l}\text { SHARING AND } \\
\text { NEGOTIATING }\end{array}$} & $\begin{array}{l}\text { Availability of } \\
\text { data to external } \\
\text { subjects }\end{array}$ & $\begin{array}{l}\text { It refers the capacity to share data with public } \\
\text { organizations, organizations of the civil society, and } \\
\text { individuals }\end{array}$ & $\begin{array}{l}\text { Gupta et al, 2010; } \\
\text { Hulbert and Diaz, } \\
2013 .\end{array}$ \\
\hline & $\begin{array}{l}\text { Multi-actor; } \\
\text { multi-sector; } \\
\text { multi-level } \\
\text { (vertical and } \\
\text { horizontal) }\end{array}$ & $\begin{array}{l}\text { It refers to the capacity to involve various actors, } \\
\text { administrative levels and sectors in the problem } \\
\text { management process. }\end{array}$ & $\begin{array}{l}\text { Ostrom, 2005; Folke } \\
\text { at } \\
\text { al.2005;Brockhaus } \\
\text { et al 2012. }\end{array}$ \\
\hline & Connectivity & $\begin{array}{l}\text { It refers to the capacity to establish linkages in } \\
\text { multi-sectorial and multi-level governance processes } \\
\text { that allows the flow of information, resources and } \\
\text { knowledge creating the conditions for learning and } \\
\text { adaptiveness. }\end{array}$ & $\begin{array}{l}\text { Engle and Lemos, } \\
2010 .\end{array}$ \\
\hline & $\begin{array}{l}\text { Degree of } \\
\text { Network }\end{array}$ & $\begin{array}{l}\text { It indicates the number of connections that an } \\
\text { organization has. }\end{array}$ & $\begin{array}{l}\text { Tompkins and } \\
\text { Adger, } 2004 .\end{array}$ \\
\hline & $\begin{array}{l}\text { Ability of } \\
\text { different } \\
\text { agencies to } \\
\text { communicate } \\
\text { and } \\
\text { constructively } \\
\text { to debate ideas, } \\
\text { information, } \\
\text { and solution to } \\
\text { problems } \\
\text { among } \\
\text { themselves. }\end{array}$ & $\begin{array}{l}\text { It concerns the ability of an organization to reflex } \\
\text { about and to learn from other systems (formal and } \\
\text { informal) avoiding the problems of organizational } \\
\text { silos (uncommunicative, non-interactive } \\
\text { organizations and practices) as well as to deal with a } \\
\text { multiplicity of challenges, and change trajectories } \\
\text { and practices as required. }\end{array}$ & Diaz et al., 2005. \\
\hline
\end{tabular}




\begin{tabular}{|c|c|c|c|}
\hline LEADERSHIP & & $\begin{array}{l}\text { It refers to the capacity to manage the different } \\
\text { processes. }\end{array}$ & $\begin{array}{l}\text { Barney and Hansen, } \\
\text { 1994; Danter et al. } \\
\text { 2000; Yoke and Tol, } \\
\text { 2002; Judge and } \\
\text { Douglas, 2009; } \\
\text { Gupta et al., 2010; } \\
\text { Darini et al., 2011; } \\
\text { Hulbert and Diaz, } \\
\text { 2013. }\end{array}$ \\
\hline \multirow{3}{*}{ RESOURCES } & $\begin{array}{l}\text { Human } \\
\text { Resources }\end{array}$ & \multirow{3}{*}{$\begin{array}{l}\text { Availability of resources both to reach a goal and to } \\
\text { reform organizational routines. }\end{array}$} & \multirow{3}{*}{$\begin{array}{l}\text { Diaz et al., 2005; } \\
\text { Gupta et al., 2010; } \\
\text { Engle and Lemos, } \\
2010 .\end{array}$} \\
\hline & $\begin{array}{l}\text { Financial } \\
\text { Resources }\end{array}$ & & \\
\hline & $\begin{array}{l}\text { Technological } \\
\text { Resources }\end{array}$ & & \\
\hline
\end{tabular}

Table 5.1: Dimensions and attributes of the inherent characteristics

\section{Organisational Learning Capacity}

The importance of learning to enhance adaptive capacity is generally recognised in the literature that provides a rather nuanced view. Institutional memory refers to the ability to get through the evaluation of processes of policy experiences (e.g. performance reporting) and convert weaknesses into opportunity by promoting social learning. Moreover, learning is related to experience as the ability to deal with everyday events, as well as extremes, effectively and efficiently (Engle and Lemos 2010). As follows, learning also refers to how experience enables questioning (and if needed modify) ideologies, frames, routines, roles and rule as well as how problems are set and solved (Gupta et al. 2010; Staber and Sydow 2002). The incapacity of an institution to figuring out the need to develop new knowledge (Cohen and Levithal 1990) may turn organisational capabilities into rigidities (Leonard-Barton 1992) under conditions of dynamicity and uncertainties. Gilpin and Murphy (2008) stress how organisational ignorance in its various forms create a critical obstacle to successful crisis management. Instead, organisational reflexivity allows an organisation to transform the context the organisation operates within (Brockhaus et al. 2012; Staber and Sydow 2002), without experiencing the environment passively. Goodin (1996) suggests that institutional learning includes willingness and preparedness to experiment.

Concerning this, different forms of learning, demanding incremental focus on the sub-text of learning can be identified in the literature. Single-loop learning suggests a progressive enhancement of action strategies without questioning the underlying assumptions. Double-loop learning (see Argyris and Schön 1978) refers to a reexamination of premises (e.g. about cause-effect relationships) within a valuenormative framework. In triple-loop learning (see Hargrove 2002) one starts to review core values and beliefs, worldviews if assumptions within a worldview do not hold anymore. Besides this, Gupta et al. (2010) highlight how learning by requiring trust among the different social actors can enhance adaptive capacity.

\section{Individual Learning Capacity}

Individuals comprehend and evaluate desirable states of development and risk ground of different knowledge, interests and values: this must be taken into account when considering adaptive capacity (Otto-Banaszak et al. 2011). Pelling and High (2005) indicate the need to open informal spaces within organisations where 
individuals and sub-groups can spontaneously share, learn, and reflect on how they act or experiment (Agrawal 2008). On the contrary, institutions not providing sufficient autonomy to individuals or groups to adapt their behaviour in response to changes are likely to constrain or reduce their adaptive capacity (Williamson et al. 2012; Inderberg 2011; Gupta et al. 2010). In turn, within the UNDP's Adaptation Policy Framework for Climate Change, the willingness to adapt is listed as a critical component of adaptive capacity. The latter depends heavily on leadership and responsibility acceptance by key stakeholders (Lim et al. 2005). Brockhaus et al. (2012) in outlining the results of the interviews in the four municipalities/ districts in Burkina Faso list different qualities, such as motivation, curiosity, openmindedness as qualities to be a "good adapter".

\section{Sharing and Negotiating}

Engle and Lemos (2010) pinpoint the capacity to network, to connect as attributes of institutional adaptive capacity in their process of unpacking governance. Additionally, they associate such characteristic with the use of knowledge as features to both support social learning and flexibility of institutions. Institutional coordination, according to Diaz et al. (2005), involves the ability of different agencies to communicate and constructively debate ideas, information, and solution to problems. Tompkins and Adger (2004) affirm that adaptive capacity is enhanced by the existence of institutions and strong networks which learn and gather both knowledge and experience as well as plan for changing environmental and policy settings and risks. In turn, Folke et al. (2005) emphases theneed to foster adaptive, flexible, and learning institutions at different scales, to respond to the non-linear dynamics of natural resources and human systems. The relevance of coordination of a multi-actor, multi-level and multi-sector approach to enhance adaptive capacity within an institutional structure is emphasised by Gupta et al. (2010), Brockhaus et al. (2012), and the National Adaptive Capacity Framework (World Resources Institute 2009). Woolcock (1999) states that not all networks are positive. Menoni and Pugliano (2013) underscore how some organisations meet very occasionally and sometimes develop conflicts regarding tasks and roles. Putnam (1993) warns that norms and networks may act as a means of discrimination or social segregation as well as may reinforce the power of some elites (see Marcus 1983). Non-members may be marginalised (Brockhaus et al. 2012); sources of information and contacts can be monopolised (Das Gupta 2001).

\section{Leadership}

Danter et al. (2000) point out that in a learning environment, continuous testing and change of leadership within management organisations is required. In line with this, Gupta et al. (2010) underscore the role of leadership in promoting a change or in motivating others to follow. According to the "Ten traits of Adaptive Organisations" developed by KPMG, leadership can be identified throughout the whole organisation. All who encourage others to accept, support and even embrace new behaviours exhibit it. Darini et al. (2011) in their assessment of the adaptive capacity of small and medium enterprises referring to leadership, management and governance structures look at balancing the necessities of internal and external stakeholders finalised to ensure a good governance and decision-making process even during emergencies. Consistent with Darini et al. (2011), Yohe and Tol (2002) indicate leadership as the capacity to determine what information is reliable, the processes by which decision-makers define which information is trustworthy, and the credibility of the decision-makers themselves. J udge and Douglas (2009) stress 
the relevance of the leadership and in particular of a trustworthy leadership (see Barney and Hansen 1994) as a dimension of organisational change capacity in their literature review of the organisational change capacity.

\section{Resources}

Many authors (Gupta et al. 2010; Engle and Lemos 2010; Diaz et al. 2005) cite such dimension as to financial and human labour attributes; others list as relevant even other resources as social capital (Brooks and Adger 2005), authority (Gupta et al. 2010), education and wealth (Engle and Lemos 2010).

\subsection{REACT IN ACTION: OPERATIONALIZING ORGANISATION'S ADAPTIVE CAPACITY}

The mechanism of operationalization of adaptive capacity is described in Table 5.2, which shows the relationship between the two categories, the Process" and the "Capacity" both described in paragraph 5.1.

Table 4 is a double entry-level table composed of two axes: "What" and "When". "What", in the column", is related to the category "Capacities". The latter, capacity, is composed of five dimensions and by a set of capacities composing each dimension. The "Organisational Learning Capacity" dimension refers to (1) ability to deal with everyday and crisis which underlines the capacity of an organisation to deal with uncertainties and surprises, to think on the base of possible scenarios, and the availability of an emergency plan to follow as references. (2) willingness to experiment refers to the ability to take the risk of making mistakes; (3) institutional memory concerns the ability of an organisation to learn through the evaluation of policy experiences and enhance the abilities converting weaknesses into opportunity. (4) Single, double, triple loops refer to the capacity to learn and thus to reform routines by enhancing them or by changing its core values; (5) "Trust is the capacity to develop ties based on trust both between individuals and groups within an organisation and between an organisation and its stakeholders.

The "Individual Learning Capacity" is made up by (1) willingness to change and to adapt refers to the capacity to embrace change and take personal action to prevent problems; (2) preparedness to experiment is related to the capacity to increase the individual capacity to self-organize and innovate fostering social capital; and (3) continuous access to information. The latter, "continuous access to information" concerns the existence of a reliable and updated accumulation of information. Information should be easily accessible and easily sharable among individuals, teams and units within an organization.

Sharing and Negotiating is composed by (1) availability of the data to external subjects; (2) connectivity; (3) degree of a network (4) multi-actor, multi-sector, and multi-level (vertical and horizontal); and (5) ability of an institution to communicate and constructively to debate ideas, information, and solution to problems among different agencies.

"Availability of data to external subjects" refers the capacity to share data with public organisations, organizations of the civil society, and individuals.

"Degree of network" indicates the number of connections that an organization has. 
"Multi-actor, multi-sector, and multi-level (vertical and horizontal)" refers to the capacity to involve various actors, administrative levels and sectors in the problem management process.

"Connectivity" refers to the capacity to establish linkages in multi-sectoral and multi-level governance processes that allows the flow of information, resources and knowledge-creating the conditions for learning and adaptiveness.

"Ability of an institution to communicate and constructively to debate ideas, information, and solution to problems among different agencies" concerns the ability of an organization to reflex about and to learn from other systems (formal and informal) avoiding the problems of organisational silos (uncommunicative, non-interactive organizations and practices). Besides, it refers to the capacity of an institution to deal with a multiplicity of challenges, and change trajectories and practices as required.

Leadership sums up the insights described earlier in this section as the capacity to manage the different processes.

Resources refer to the availability of human, financial and technical resources both to reach a goal and to reform organisational routines.

"When", in the row, refers to the category of the "Process" composed by four phases and by a range of attributes. The problem-finding phase is made up by the three attributes: (1) variety of problem frames; (2) capacity to collect and manage data; (3) and capacity to predict problems from collected data.

"Variety of problem frames" refers to the capacity to view a dilemma that needs to be solved through different frames, to reformulate the problem from other standpoints and/ or change the paradigm of reference.

"Capacity to collect and manage data" concerns on the one hand with the capacity to agree in goals, definitions, and methods to collect data; on the other hand with the capacity to organize data in a way that contributes to a better knowledge of the existing resources and facilitating their management in ordinary situations as well as in the situation of uncertainty and surprise.

"Capacity to predict problems from collected data" is related to the capacity to be sensitive to perceive a situation in which there are problems, to recognize a situation as problematic.

The problem-shaping phase is composed by two attributes: (1) Capacity to understand and outline the dilemma's borders, which emphases the capacity to define the features of a situation that need to be resolved; (2) proactivity indicating the action of acting in advance to deal with an expected difficulty.

The problem-solving phase comprises four attributes: (1) diversity of solutions, such as the capacity to develop appropriate, reversible, and innovative solutions as well as the ability to decide under uncertainty; (2) clear mechanism for enforcing rules; (3) preventing rigid persistence, which refers to conflict management for creating constructive solutions; (4) and organisational capacity to inform about their decisions and of the procedures to implement them.

The decision-taking phase is made up of three attributes: (1) responsiveness; (2) monitoring and evaluation; (3) and end-user oriented language. "Responsiveness" 
refers to the capacity of an organization to acquire feedbacks and respond to such stimuli. Whereas, "monitoring and evaluation" mean the capacity of an organisation to monitor the application of the solutions undertaken and to evaluate their degree of implementation, correspondence to the criteria defined and success of such solutions.

Each flag in the table highlights the existence of a relation between a specific capacity ("What") and the phase of the process ("When") in which this specific organisational capacity is used. Furthermore, each flag regarding the same capacities shows how such ability plays a different role according to the specific problem management phase it refers to. For instance, in the problem-shaping phase, institutional memory may refer to a learning process related to the mechanism of defining and scoping a problem, whereas within the problem- solving phase the same attribute, institutional memory, indicates the capacity of an organization to design potential solutions to a problem on the base of the acquired experience. 


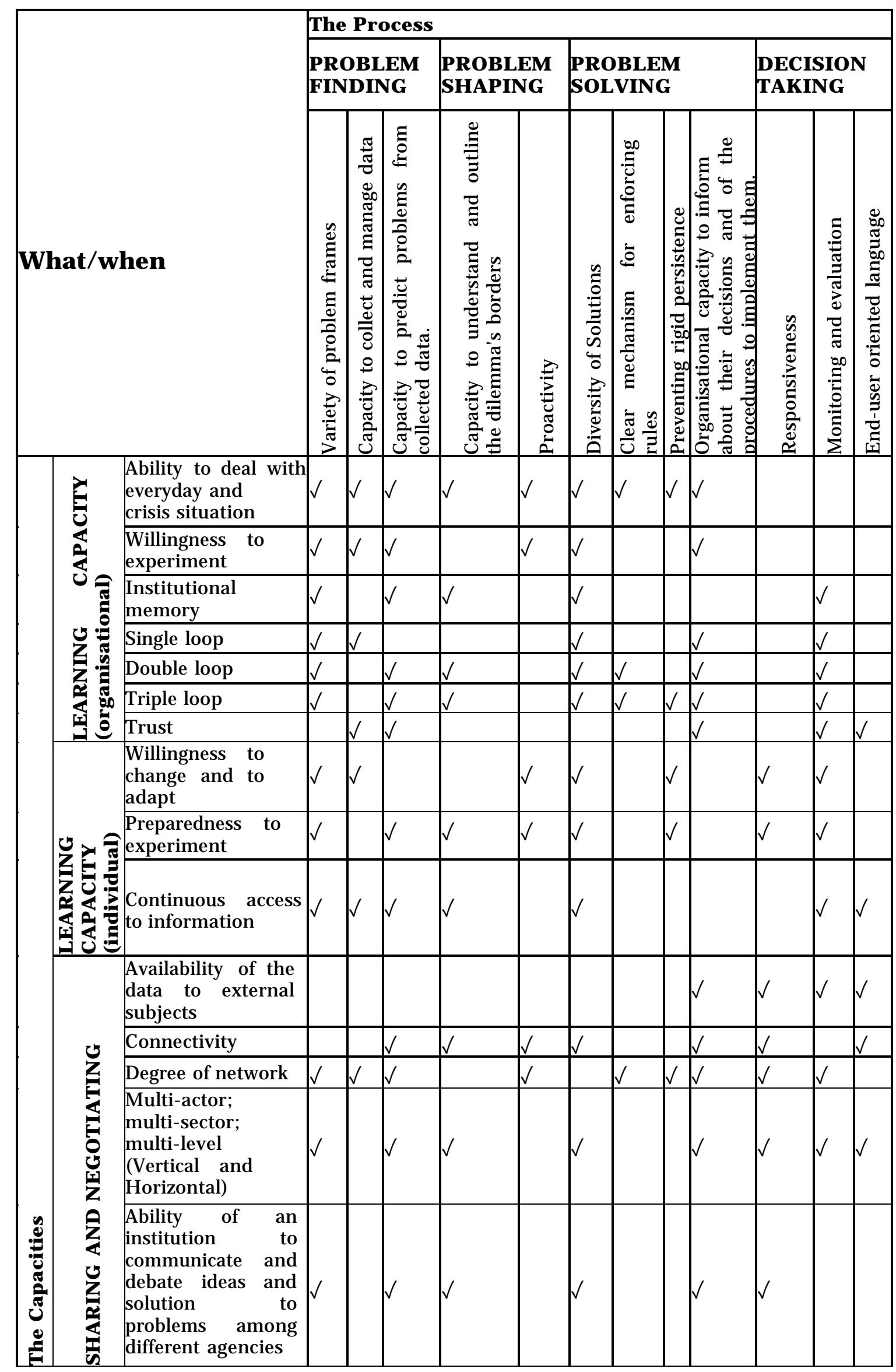






Table 5.2: REACT IN ACTION: links between capacities and process attributes to operate organisation's adaptive capacity

\subsection{ADAPTIVE CAPACITY AND TIME SCALE}

Furthermore, the conceptual framework here proposed can be used to assess the capacity of organisations to respond to different types of problems, here identifies as a surprise, current, and future problems (Figure 5.2). The inability to recognise a turning point or a specific issue that can lead the whole system towards an entirely different scenario, unexpected if only the general trend and the common elements are considered, produces the "surprise" problems. Within the category of "surprise problems" are clustered together all those problems characterised by being unexpected and requiring the activation or use of those routines applied during the "emergency time". This can be the case of unrecognised state of drought due to a lack of a monitoring system, of earthquakes affecting the pipeline system, of a blackout cutting off the energy power of water pumps used to capture underground water or to control water flows for cropping. 
Once the emergency phase is over, unexpected problems may become current problems in terms of capacity to acknowledge them [if organisational ignorance does not prevail, see Gilpin and Murphy (2008)], for which routines are established and updated. Current problems refer to all those issues happening during the "peacetime" and are characterised by a short- medium-term solution, such as water quality, customer expectations, and regulations. However, as stressed by Evans et al. (2004) referring to flood risk, 'decisions taken today will have a profound impact on the size of flood risks that future generations will need to manage. They will also strongly influence the options available for managing those risks', and while transferring such concept to manage problems, it is possible to note how current problems may hideand thus generate an "unexpected problem" in the future as well as it shrinks the range of suitable solutions.

The category of "future problems" consider all the issues (that should be understood here as challenges and opportunities) requiring a medium-long term to be dealt with. Such problems may consist of expanding technological application or decreased availability and adequacy of water resources (e.g. emerging contaminants). Different types of problems require different kinds of actions. Analysing in detail the relation time-action, at the lowest threshold the smallest the required degree of change in the organisational routine to respond to a problem, the faster will be the capacity of an organisation to respond to a problem (Figure 5.2 ).

The operational level of an organisation is able to respond to a problem most rapidly at (the blue line with the highest increasing slope); however, the degree of the change from an initial to target state is the smallest, which underlines a transformation only in the way of doing something without affecting the other tiers of an organisation. At the highest threshold, the decision level can respond to a problem with a substantial change in magnitude, but the latter requires a longer time to occur (the green line with a smaller slope). Furthermore, such change will have a chain effect requiring thus a modification both at the management and at operational levels.

It worth to notice that each response given by the organisation to a dilemma and the following change in one of the organisational levels (operational, management, and decision) has to be assessed against the uncertainty degree of. De Marchi et al. (1993) identifies in their work different types of uncertainty, such as scientific, social, legal/ moral, institutional, proprietary and situational. The latter that can be considered as the summary of the different types of uncertainty plays a critical role being related to the need of acting under conditions of limited and in insufficient general information to support a decision. Therefore, it is critical within an organisation not only to recognise the different uncertainties to be managed in order to be aware of the possible interrelations among the different types but also to select which is the best organisational level to respond promptly to a problem. 


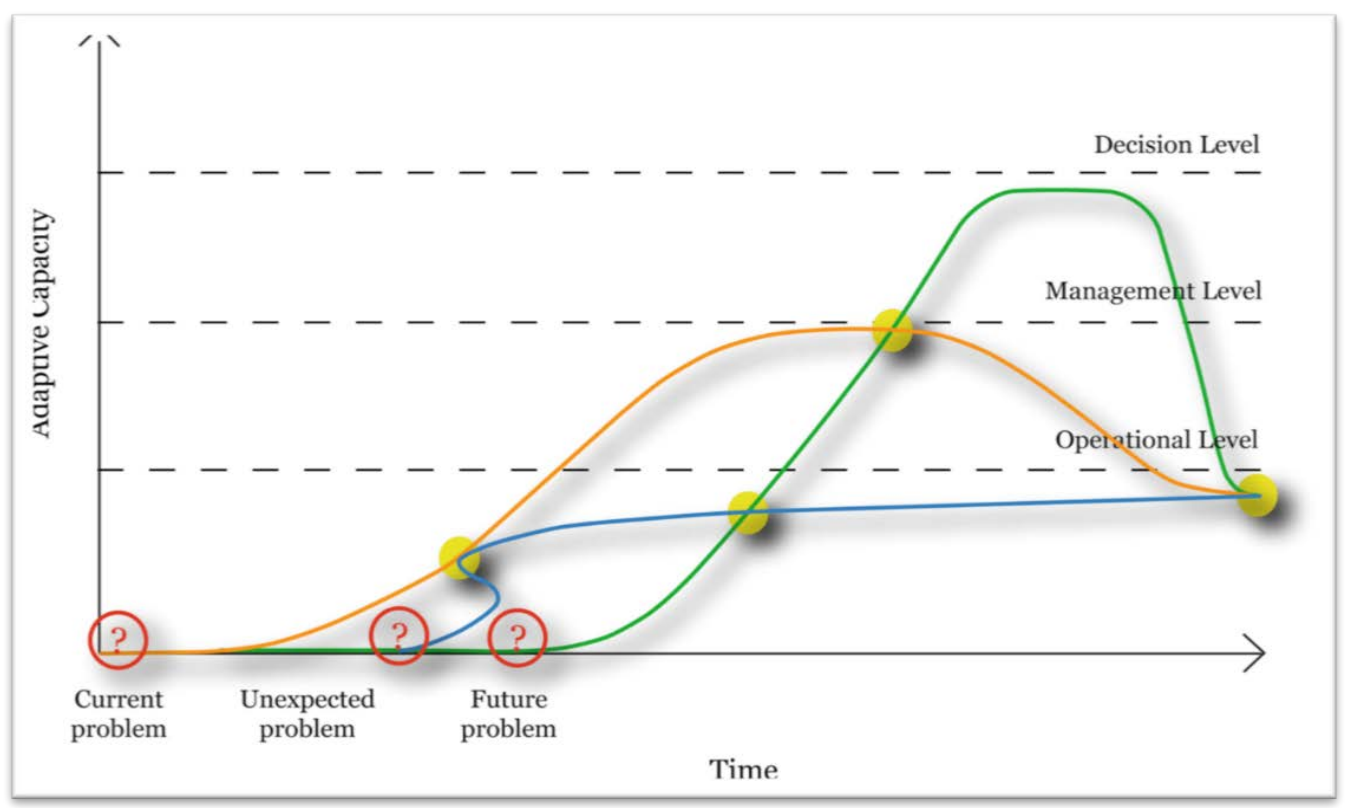

Figure 5.2: Relation between adaptive capacity of an organization and time (source: Author)

\section{References}

Agrawal A ( 2008) The Role of Local Institutions in Adaptation to Climate Change. International Forestry Resources and Institutions Program Working Paper 081-3

Argyris C, Schön D (1978) Organisational Learning: A Theory of Action Perspective. Addison Wesley, Reading MA

Barney J,Hansen M (1994) Trustworthiness as a source of competitive advantage. Strategic Management J ournal 15:175-90

Brockhaus M, Djoudi H, Kambire H (2012) Multi-level governance and adaptive capacity in West Africa. International J ournal of the Commons 6(2):200- 232

Brooks N, Adger WN (2005) Assessing and enhancing adaptive capacity. In: Lim B, Spanger-Siegfried E (eds) Adaptation Policy Frameworks for Climate Change: Developing Strategies Policies and Measures. UNDP- GEF

Cohen WM, Levinthal DA (1990) Absorptive capacity: A new perspective on learning and innovation. Administrative Science Quarterly 35:128- 152

Collins DJ (1994) Research note: how valuable are organisational capabilities? Strategic Management J ournal 15:143-152

Cyert RM, March JG (1963) A Behavioral Theory of the Firm. Prentice Hall, Englewood Cliffs, NJ

Danter KJ, Griest DL, Mullins GW et al (2000) Organisational Change as a Component of Ecosystem Management. Society and Natural Resource 
13:537-547

Darini M, Pazhouhesh H, Moshiri F (2011) Relationship between Employee's Innovation (Creativity) and time management. Procedia Social and Behavioral Sciences 25:201- 213

Das Gupta M (2001) State-Community Synergies in Development: laying the basis for collective action. World Bank Development Research Group

De Marchi B, Funtowicz S, Ravetz J (1993) The management of uncertainty in the communication of major hazards. J oint Research Centre at ISPRA EUR 15268

Diaz HP, Hulbert M (2013) The Need for Adaptive Water Governance: Lessons from Canada and Chile. In Knieling J, Walter LF (eds) Climate Change Governance. Springer, Heidelberg p 171-184

Diaz H, Rojas A, Richer L et al (2005) Institutions and Adaptive Capacity to Climate Change. IACC Project Working Paper No. 9

Engle NL, Lemos MC (2010) Unpacking governance: Building adaptive capacity to climate change of river basin in Brazil Global Environmental Change 20 pp. 4-13

Evans EM, Ashley R, Hall J et al (2004) Foresight. Future flooding Scientific Summary: Volume I - Future risks and their drivers. Office of Science and Technology London UK

Folke C, Hahn T, Olsson P et al (2005) Adaptive governance of socialecological systems. Annual Review of Environment and Resources 30(1):441- 473

Gilpin DR, Murphy PJ (2008). The complexity of information and assimilation knowledge and ignorance. Oxford University Press, London

Goodin RE (1996) Institutions and their design. In: Gooding RE (ed.) Theory of Institutional Design. Cambridge University Press, Cambridge

Gupta J, Termeer C, Klostermann J et al (2010) The Adaptive Capacity Wheel: a method to assess the inherent characteristics of institutions to enable the adaptive capacity of society. Environmental Science \& Policy 13(6):459-471

Hallagate S (2009) Strategies to adapt to an uncertain climate change. Global Environmental Change 19(2):240-247

Hargrove R (2002) Masterful Coaching. Revised Edition J ossey- Bass/Pfeiffer Wiley, USA

Judge WQ, Douglas T (2009) Organisational Change Capacity: The Systematic 
Development of a Scale. J ournal of Organisational Change Management 22(6):635-649

Leonard-Barton D (1992) Core capabilities and core rigidities: A paradox in managing new product development Strategic. Management J ournal 13(8):111-125

Lim E. Pan S. and Tan C. (2005) Managing user acceptance towards enterprise resource planning (ERP) systems - understanding the dissonance between user expectations and managerial policies. European Journal of Information Systems 14(2):35-149

Marcus GE (ed) (1983) Elites Ethnographic issues. Albuquerque University of New Mexico Press

Menoni S, Pugliano A (2013) Civil Protection and Crisis Management. In Bobrowsky P (ed) Encyclopedia of Natural Hazards. Springer, Dordrecht, p 69-77

Otto-Banaszak I, Matczak P, Wesseler J et al (2011) Different perceptions of adaptation to climate change: a mental model approach applied to the evidence from expert interviews. Regional Environmental Change 11(2):217- 228

Pelling M, High C (2005) Understanding adaptation: what social capital offer assessments of adaptive capacity. Global Environmental Change 15:308- 319

Putnam R (1993) The Prosperous Community: Social Capital and Public Life. The American Prospect 4:35-42

Smith JB ( 1997) Setting priorities for adaptating to climate change. Global Environmental Change 7(3):251-264

Staber U, Sydow J ( 2002) Organisational adaptive capacity: A Structuration Perspective. J ournal of Management Inquiry 11 (4): 408-424

Tompkins EL, Adger WN (2005) Defining response capacity to enhance climate change policy. Environmental Science and Policy 8:562-571

Woolcock M ( 1999) Managing risk shocks and opportunity in developing economies: the role of social capital. The World Bank Development research group

Yohe G, Tol RSJ ( 2002) Indicators for social and economic coping capacity - moving toward a working definition of adaptive capacity. Global Environmental Change-Human and Policy Dimensions 12(1):25-40 


\title{
Chapter 6: Bolivia Case Study
}

\begin{abstract}
This chapter uses survey data, interviews, and archival research to examine impacts of past droughts and recent environmental changes in the Municipality of Tomave (Potosí, Bolivia), and to investigate how water organisations face droughts, climate change and their capacity to adapt to such. Besides, this chapter draws on qualitative data obtained by interviews and literature review to explain why specific approaches develop (or not) to water management.
\end{abstract}

Keywords. Drought, Climate Change, Water management, water management organisation, Bolivia

\subsection{WATER IN BOLIVIA}

Bolivia has abundant freshwater resources, but the distribution and access are not equal, and they reflect geographical differences, which characterized the country (Water for People 2006; World Bank 2004; Earthtrends 2003; FAO 2000). Agriculture is the sector using the largest quantity of water; roughly $81 \%$ of extracted water in Bolivia it is used for agriculture (USAID 2010). Notwithstanding, only $11 \%$ of the agriculture surface use irrigation systems delivered through canal and ditch systems, providing food security to one-third of the population. Further lack of access to safe water affects barely $40 \%$ of the whole population and within this context differences between the percentage of urban population who cannot access to water and agriculture ones, respectively $10 \%$ and $56 \%$ can be highlighted (WHO and UNICEF 2004).

Bolivia has scarce systems for water distribution as well as for disposal and treatment of greywater and solid wastes, which causes environmental damage through contamination of both surface and groundwater (FAO 2000; Water for People 2006). Hence, water quality is affected by high levels of waterborne disease as a result of poor management of mining and hydrocarbon extraction, agro-toxins, pesticides, and solid waste.

Competition for water use and distribution has increased, specifically between the demands for domestic use versus agricultural irrigation due to rising urban and peri-urban populations. Besides, significant imbalances in potable water distribution exist between wealthier enclaves and those that are poor and populated by indigenous people (Calvo 2006; EC 2007).

\subsection{WATER BY-LAWS}

After a long and conflicting process show in the movie "Tambien la Lluvia" (released in 2011). The movie is an excellent illustration of the long conflict that started in 2000 by the city of Cochabamba opposing the water privatization process. In 2009, the new State Constitution (section 373) recognized water as a fundamental right to life. The same section declares: "water resources [...] cannot be the object of private acquisition as well as its provision".

Further, the section 374 of the New Constitution of the State, approved on the 25th J anuary 2009, asserts "It's a duty of the State to manage, rule, protect and plan the adequate and sustainable use of water, including social participation and the guarantee of the access to water for all inhabitants". The fifth chapter of the Constitution entirely dedicated to water emphasizes its social and cultural role, denying a simple economical approach. Privatization of hydrological resources is not allowed, the section 309 of the Constitution states that "the administration of 
basic services related to drinking water and sewage directly can be carried out by public, communitarian, cooperative or mixed enterprises" (GOB Constitution 2009). There are some ambiguous points, mostly with reference to the inclusion of private company participation (e.g. mixed enterprises) in the possible mechanisms of water management (Minelli 2012).

The current legal framework governing water is characterized by a large number of rules, which are contradictory and where rights are not always clearly defined. Water resources are regulated by the general law regarding specifically the water resources, the 1906 Water Law (Ley de Dominio y Aprovechamiento de Aguas), which has been partially abrogated and provisions are assorted in more recent legislation, including the Environmental Act, the Mining Code, the Electricity Act, Water and Sanitation Services Law, the Irrigation Law, and the Hydrocarbons Act. Attempts to issue a unique legislative text regulating water resources management have been unsuccessful to date (Calvo 2006). As highlighted by Castrillo et al (2006), one of the major problems for integrated water management in Bolivia is the institutional legacy management system that is still focused on the regulation of uses for every single sector of consumption, such as agriculture, energy and domestic. Furthermore, there is a lack of appropriate planning mechanisms regulating water uses among different groups of interest.

\subsection{INTRODUCTION OF THE STUDY AREA}

The Municipality of Tomave belonging to the Quijarro Province(Potosí) (Figure6.1) is located in the Southern Altiplano region of Bolivia, which is an extensive plateau located at an altitude that ranges from 3600 to 4100 meters above sea level. The low rainfall rate distinguishes this region significantly from the central and northern highlands. Furthermore, the close presence of the Uyuni Salt Flat with a surface of $12500 \mathrm{~km} 2$ defines many of the ecological aspects of the municipality. The area is characterized by an arid climate, with extreme temperatures that range from $-11^{\circ} \mathrm{C}$ to $30^{\circ} \mathrm{C}$. The number of frost nights is $160-257$ per year and precipitation is $140-250 \mathrm{~mm}$ per year. 


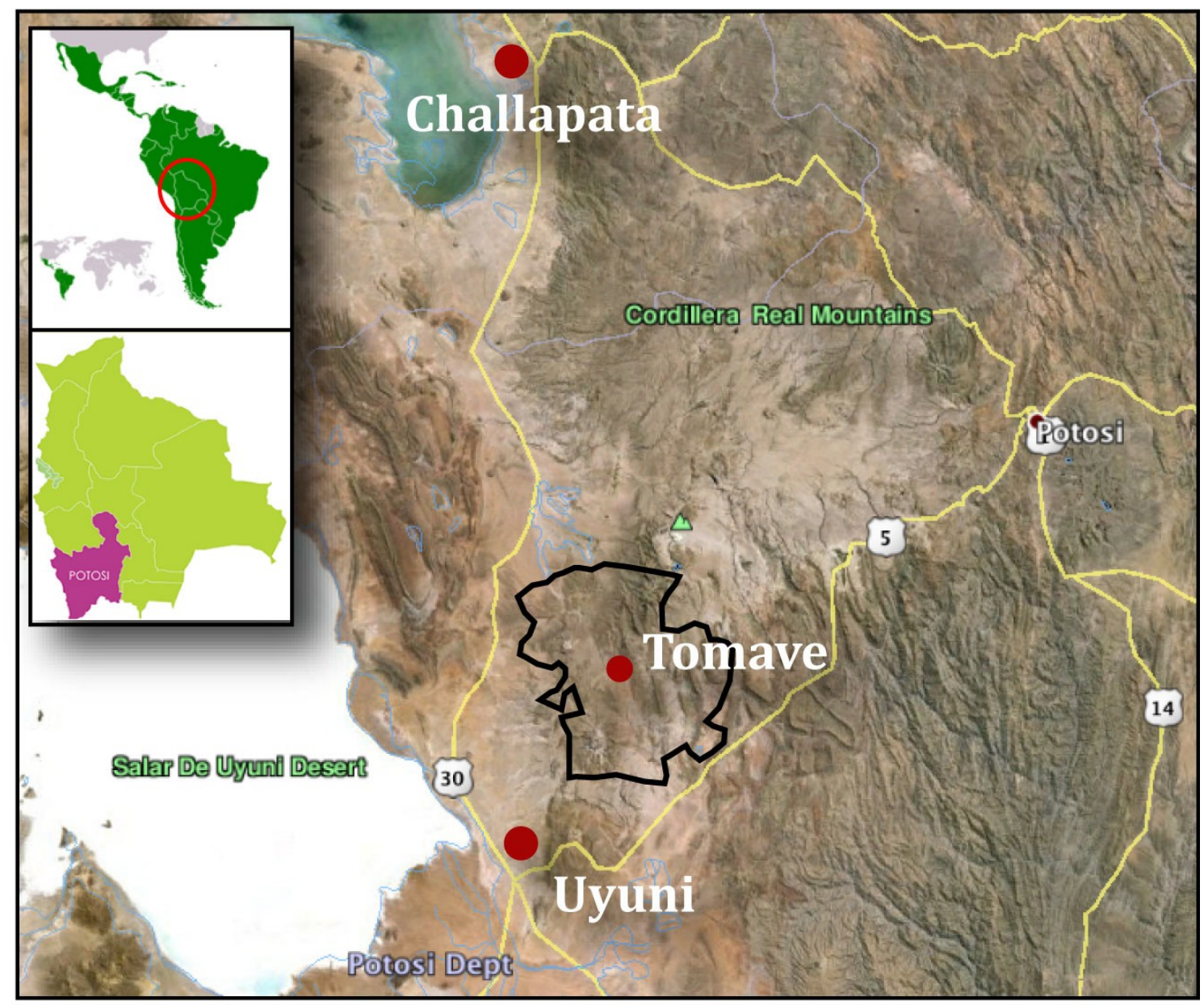

Figure 6.1: Municipality of Tomave (Potosi) - Case Study area

The Municipality of Tomave is composed of 11 cantons where 12,764 people live. The main economic activities are agriculture, breeding livestock and llamas, which represent the largest cattle (47.800 units) in the province. In addition, there has been a steady increase (around 10.000 units) in the vicuñas population (that is a wild camel famous for its valuable fur), and they are increasingly gathering down from the mountains to the prairies inhabited by lamas. Concerning agriculture, the municipality is experiencing an emerging pattern of quinoa mono-cropping growth, increasing water scarcity rates; ecological degradation change and; social tensions induced by the mono-cropping transition.

\subsection{ANALYSES THE IMPACTS ON THE SOCIO-ECOLOGICAL SYSTEM OF PAST DROUGHT EVENTS}

The Municipality of Tomave is composed of 11 cantons where 12,764 people live. The main economic activities are agriculture, breeding livestock and llamas, which represent the largest cattle (47.800 units) in the province. In addition, there has been a steady increase (around 10.000 units) in the vicuñas population (that is a wild camel famous for its valuable fur) and they are increasingly gathering down from the mountains to the prairies inhabited by lamas. Concerning agriculture, the municipality is experiencing an emerging pattern of quinoa mono-cropping growth, increasing water scarcity rates; ecological degradation change and; social tensions induced by the mono-cropping transition. 


\subsection{ANALYSES THE IMPACTS ON THE SOCIO-ECOLOGICAL SYSTEM OF PAST DROUGHT EVENTS}

The drought crisis that occurred in 1982-1983 was one of the heaviest in Bolivia. Studies carried out by the National Institute of Statistics and based on information from the Departmental Development Corporations estimate that 1,585,686 people in rural areas were affected by drought impact in seven departments, including the district of Potosí. An area of 380,000 $\mathrm{km}^{2}$ was affected, almost $90 \%$ of the Altiplano, $70 \%$ of the valleys and $10 \%$ of the lowlands (Ministerio de Desarrollo Sostenible y Planificación, 2007). The Emergency Committees Reports hold that as a consequence of soil erosion farmers located in the district of Cochabamba, Potosí and Oruro lost between 80 and 100\% of their production. Losses were concentrated in agricultural production because of soil erosion. Low food availability due to overconsumption of seeds leads to a situation of food insecurity. Moreover, according to a study by the Andean Development Corporation (CAF), El Niño 1997/ 98 caused a loss of US\$530 million in Bolivia (equivalent to $7 \%$ of national GDP), 53\% of which consequent to the droughts in the Altiplano and $47 \%$ from the floods in the North and East (Oxfam 2009).

In 2003, adverse weather conditions (hail, drought and flood) caused economic losses in the Potosí district affecting 17,756 families and 13,712 hectares cropped with quinoa, potatoes, cereals and beans. In turn, in 2008 recurrent drought and flood events affected 16 provinces, 32 municipalities, 640 Communities, 23,734 families causing the loss of 3,916 cattle as well as 24,465 hectares cultivated with quinoa, potato, bean, corn, onions, wheat.

In 2009, recorded events of drought, hail and flood, affected 14 provinces, 25 municipalities, 304 communities and 11,026 families. Moreover, a loss of 10274 ha cultivated with quinoa, corn, potato, bean, wheat, fruit and cereals, and a loss of 7,769 head of cattle lost was recorded. During the year 2010, the District of Potosí suffered a series of adverse natural phenomena such as prolonged drought, hail, frost, flood, hurricane, affecting 16 provinces, 31 municipalities, 286 communities, and 11,381 families (Figure 6.2). The impact of the natural phenomena mentioned above during the year of 2010 affected the economy of the department widely, especially in agriculture, producing the loss of different types of crops such as quinoa, potato, bean, maize, barley, wheat, vegetables and fruit (UGRP 2010).

The 2016 drought-affected 19,454 families (1,600 in the Municipality of Tomave), 14,665 ha of cropping and 19,339 head of cattle in the Potosí district. To reduce the impacts on the cattle were sent to 13 Municipalities of the Potosi district (and Tomave was one of these) 966 bottles injectable antiparasitic agents, 4,516 bottles of vitamin, 21,049 disposable metal needles and 21,049 disposable syringes. 


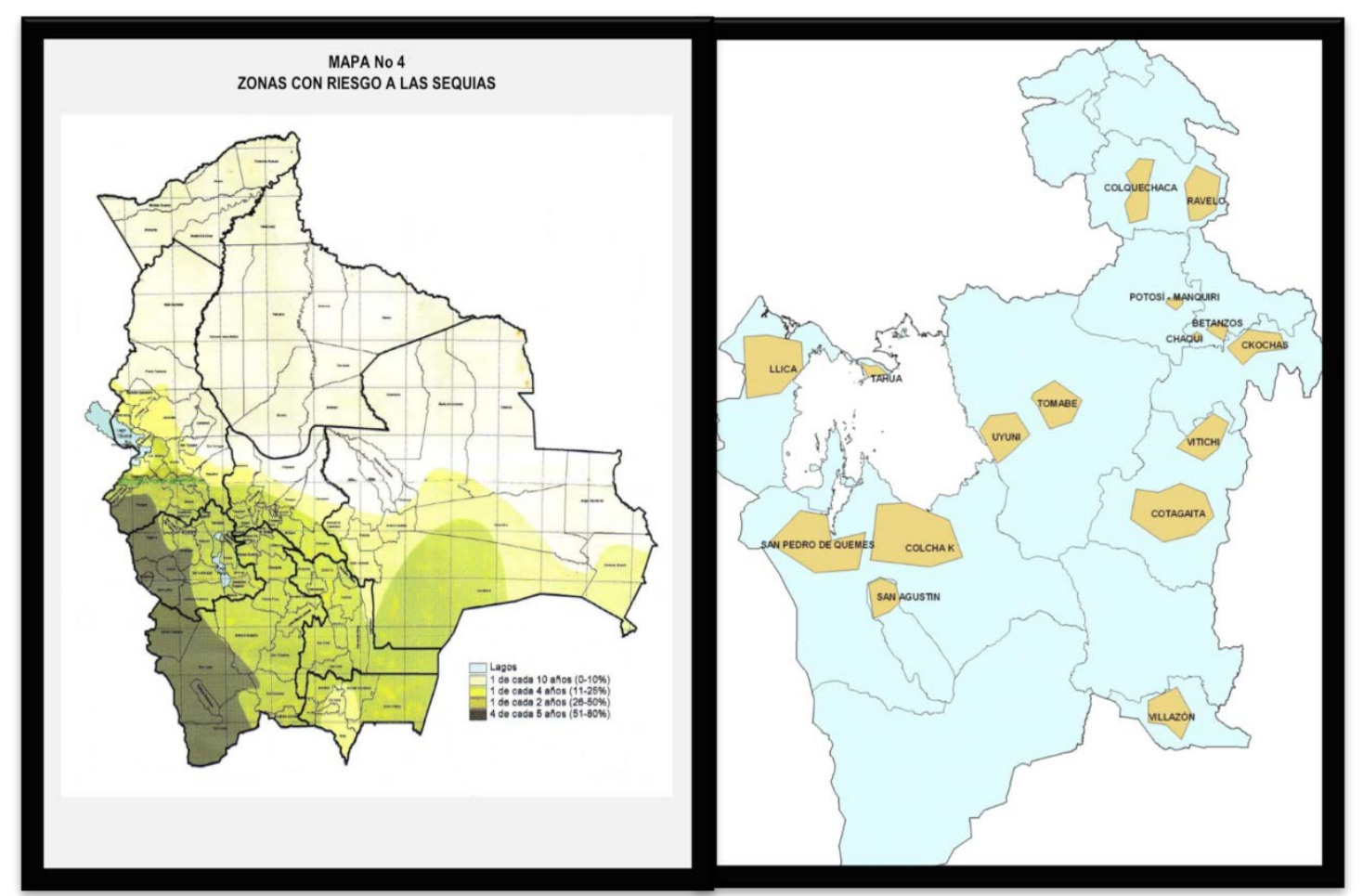

Figure 6.2: Drought risk area in Bolivia (left); Drought event in the Potosì District in 2010-2011 (right) (Source: Emergency Plan of the Potosì District)

\subsection{CLIMATE CHANGE AND DIRECT AND INDIRECT EFFECTS}

The Bolivian population has always been exposed to extreme hydro-meteorological and climate variability, due in particular to the influence of El Niño (ENSO), which, regardless of climate change, affects different areas of the country (World Bank 2010). According to the Fourth Assessment Report of the Intergovernmental Panel on Climate Change (IPCC), arid and semi-arid regions are particularly sensitive to possible decreases in rainfall. The IPCC (2014) estimates that temperatures increase in South America will on the range between $1.7^{\circ} \mathrm{C}-6.7^{\circ} \mathrm{C}$. Although the evidence of climate change in Bolivia is still little studied, available documents on climate change in the area point out: a) scientific observations, b) scarcely systematized local perceptions, and c) generated according to climate models characterized by high levels of uncertainty. A study of the National Climate Change (Ministerio de Desarrollo Sostenibley Planificación, 2007) reports the temperature rise in the Andes from observations on the incidence of malaria in highland communities. Besides Vuille \& Bradley (2000) and Francou et al. (2003) observed a clear relationship between the melting of glaciers and El Niño events with a consequent temperature increase. Moreover, in a study related to the impacts of climate change on the rainfall trends in Bolivia, Seth et al. (2010) identify a decrease in precipitation in spring (September- November), which would affect the water resources. This trend is coherent with what has been observed by a study conducted by the Ministerio De Planificación del Desarrollo in collaboration with the Viceministerio de Planificación Territorial y Medio Ambiente based on the Normalized Difference Vegetation Index (NDVI) showing a reduction between September to October and increase of precipitation in November highlighting a shortening of the rainy phase Ministerio de Desarrollo Sostenible y Planificación, 2000). The IPCC (2014) adds that the increase in atmospheric temperature has led to an acceleration of glacier retreat in the Andean region, with consequent impacts on water availability and the generation of hydroelectric power. According to Ramirez (2001), the higher temperature increase in the coming years will affect the 
Andes considerably. This statement is sustained by a recent report regarding the effects of the melt glacier phenomenon on the communities living in the Bolivian Altiplano (Agua Sustentable 2010).

Life in the Andean mountains is harsh owing to extreme climatic conditions, the most common risk factors being drought, floods, frosts, hail and saline soils. More severe and extreme climate events during the next years, with severe impacts on food production and food security, are expected (Easterling et al. 2007; Stern Review 2007). Interviews carried out in little villages in the southeast of the Potosí district and stories told by some local storytellers suggest that farmers perceive a change in climate in the last twenty years. Table 6.1 summarizes which phenomena they have been noticing and their impacts on water availability in this area. Moreover, in some villages in this part of the district, due to higher temperature farmers are cropping vegetables or wheat that they could not cultivate only 15 years ago. Notwithstanding, they state that the risk to lose the harvest is now higher than before.

\begin{tabular}{|c|c|}
\hline Climate & Water availability \\
\hline Stronger and continuous wind & Reduced river flow. Before the river rose its \\
\hline $\begin{array}{l}\text { Lesser number of rainfall } \\
\text { events }\end{array}$ & $\begin{array}{l}\text { flow when it was windy or cloudy in the } \\
\text { headwaters }\end{array}$ \\
\hline $\begin{array}{l}\text { Increasing in quantity and } \\
\text { duration of continues frost } \\
\text { days }\end{array}$ & \multirow{6}{*}{ Reducing the flow of the springs } \\
\hline Lower temperature & \\
\hline More drought events. & \\
\hline Delay in rainy day & \\
\hline Less snow events & \\
\hline Hailstorm & \\
\hline Less snow events & \multirow[b]{3}{*}{ Reduction in the volume of flow } \\
\hline Delay in rainy day & \\
\hline $\begin{array}{l}\text { Lesser number of rainfall } \\
\text { events }\end{array}$ & \\
\hline
\end{tabular}

Table 6.1: Climate change phenomenon and their impacts on water availability

Agriculture in the department of Potosí is mainly based on climatic variables. In other words, because farmers and communities do not have any water storage system their production is strictly linked to precipitation, hence agriculture is very vulnerable to droughts, frosts and almost completely unprotected against hailstorms (Lordemann and Aguilar Salas 2009). In turn, such a variable climate often leads to less agricultural output and therefore higher, or more volatile, food prices. Furthermore, the semi-arid mountainous areas are highly vulnerable to the disruption of local hydrological patterns, and the higher temperatures could have a significant effect on the central role of bofedales. Bofedales are a wetland located in the Andean mountains and considered a native prairie with permanent moisture, which plays a key role in regulating local water supplies by releasing water during the dry season. The permanent snow that existed until 20 years ago now only remains for 3-4 months. Besides, the river flows are increasingly falling and allow the cultivation of grass and legume, which could not ripen in these areas until some years ago. The drought is accentuated from October to December, and it is regular until J anuary (ACRA and ARCCA 2004). A reduction both in the amount of available water and in the number of bofedales is likely exacerbated by the lack of management strategies, information on climate change and institutional 
constraints. In the area of Potosí, the rural poor are often subject to political and economic marginalization and ignorance that leaves them with few options to improve their livelihoods.

\subsection{FACING DROUGHT: THE EARLY WARNING SYSTEM AS A FIRST RESPONSE}

It is often possible to provide early warning of an emerging drought due to the characteristics of such natural hazard. This information allows for a shift from reactive to proactive hazard management and represents a change in focus from disaster recovery to disaster prevention, which has not been accomplished and could be instead vital in Bolivia and particularly in the Potosí district.

A survey conducted by ISDR Platform for the Promotion of Early Warning discovered that early warning systems for drought are more complex than those for other hydro-meteorological hazards and are consequently, relatively less developed globally (ISDR 2007). Augmenting forecast and early warning information with decision-support capabilities to provide information regarding options for reducing vulnerability to drought enhances local coping capacities and provides an important mechanism for reducing drought risk. Promoting the inclusion of indigenous or local groups in drought monitoring and early warning systems is essential for developing appropriate local drought indicators, verifying the occurrence of drought, and communicating the warnings to local populations.

\subsection{EARLY WARNING SYSTEM IN THE POTOSÍ DEPARTMENT}

With reference to the case study, in 2009 the Potosí district developed an Early Warning System which provides hydro-meteorological information regarding the probability to have a natural or human-induced disaster, which may impact on a Municipality, a region or the whole district, in order to be able to face such event in an organized and appropriate way. The Drought Early Warning System of the Potosí Department is based on three levels (FAO Bolivia 2009).

The first level is composed of the institutions that generate information through monitoring points (weather stations or others) that are in various communities in the department. This level includes the National Service of Meteorology and Hydrology (SENAMHI) that monitors the weather conditions of the department. The second level is represented by the Departmental Monitoring Centre, which belongs to the Department of the early warning system, implemented within the Risk Management Unit of the Prefecture. This unit is responsible for the reception and dissemination of meteorological and hydrological information as well as of disseminating the degree of alert to departments and municipalities. The third level is made of the users of the System Department of Early Warning System, Municipal Early Warning, communities, to the Prefect and to the Mayor, according to the law 2140, for the activation of operation centres (EOC's) at the Departmental and Municipal level. This early warning system has been applied to crop-graze production in various municipalities in the Potosí district. Such a system combines expert knowledge with local knowledge (Fundación Fautapo and Compasur 2012). The former is embodied in ten weather-monitoring stations that check: a) weather temperature; b) precipitation; c) wind.

Furthermore, through 120 stations widespread in areas dedicated to quinoa farming the susceptibility to wind erosion and the soil humidity are evaluated. The local knowledge is based instead on forty-three bio-indicators divided into three categories: 1) vegetation; 2) animals; 3) climate and stars that are checked along the entire year. Although such system should be considered rather advanced, the 
interviews accomplished in May of 2012 with two different quinoa farmer associations (ARPAIAMT and SOPPROQUI) and people living in the communities located in this area show that the reliability of the system is quite low. The negative evaluation is due to two main factors. On the one hand, the low level of trustability of the National Service of Meteorology and Hydrology (SENAMHI) and its forecast; on the other hand, farmers ignore the existence of an early warning system. Hence, farmers prefer to cultivate their crops only according to their ancient knowledge. Still, as declared by the "Curaca por ayllu" (the supreme authority of an indigenous community) of El Asiento (a village in the southern part of the Potosí district) during the interview "nowadays, such ancient knowledge is not so reliable anymore because of climate change animals and plants are no more acting in the same ways." Therefore, the farmers' point of view concerning the early warning system is clearly in contrast with the view of the regional government representatives, who consider the system as rather efficient.

A technical report (de Keizer and Hunink 2017) on drought information and early warning systems issued by a Dutch and a World Bank technical team after the 2016 drought event states the fact that the SENAMHI hydro-meteorological bulletins' seem not to be well adopted by the relevant institutions, which should make use of this type of information, with a few exceptions. In addition, the report underscores how even though the SENAMHI publishes drought warnings based on the El Niño oscillation, the accuracy of this type of forecasts is an issue (probably due to a mix of factors: the inherent uncertainties with this type of forecasts, the particular climatic system of Bolivia, lack of capacity at SENAMHI, etc.). Besides, it concludes stating that the SENAMHI is under-budgeted and suffers a severe lack of capacity (staff and educational/professional level) as well as lack of vision on the future of the organization and embedment with the other related institutions.

Despite this, a recent study (Canedo Rosso et al. 2018) working on the relation between ENSO and droughts provides insights (e.g. the relation between ENSO phases and crop yield) for improving the early warning system used in the region and to enable a more pro-active approach to disaster risk management.

\subsection{BOLIVIAN WATER MANAGEMENT}

From the "War for water" of Cochabamba to water as a human right

After a long and conflicting process show in the movie "Tambien la Lluvia" (released in 2011). The movie is an excellent illustration of the long conflict that started in 2000 by the city of Cochabamba opposing the water privatization process. Once the war ended up, in 2006, the Ministry of Water was created to reach an agreement among different organizations. Although today the name of the governmental institution has changed (currently, Ministerio de Medio Ambiente y Agua/ Ministry of Environment and Water), its water policy defined and detailed in the National Basin Plan (in Spanish, Plan Nacional de Cuencas - PNC) is still the same. Nine years after the Cochabamba Water War, the new State Constitution (section 373) recognizes water as a fundamental right to life. The same section declares: "water resources [...] cannot be the object of private acquisition as well as its provision". Further, the section 374 of the New Constitution of the State, approved on the 25th J anuary 2009, asserts "It's a duty of the State to manage, to rule, to protect and to plan the adequate and sustainable use of water, including social participation and the guarantee of the access to water for all inhabitants". Therefore, not only water is recognized as a human right but also the protection of the environment is seen as a key policy goal. 


\subsection{ACTORS INVOLVED IN THE WATER MANAGEMENT}

The water sector is organized through institutional structures acting at the national, regional and local levels. The main organizations in Bolivian water management are (Table 6.2)

\begin{tabular}{|c|c|c|}
\hline $\begin{array}{l}\text { Bodies involved } \\
\text { in the water } \\
\text { management }\end{array}$ & Level & Role \\
\hline $\begin{array}{l}\text { Ministry of } \\
\text { Environment and } \\
\text { Water (Ministerio } \\
\text { de Medio Ambiente } \\
\text { y Agua - MEV) }\end{array}$ & $\begin{array}{l}\text { National } \\
\text { Actors }\end{array}$ & $\begin{array}{l}\text { The MEV develops and implents } \\
\text { policies, standards, plans, programs } \\
\text { and projects for the conservation, } \\
\text { adaptation and sustainable use of } \\
\text { environmental resources and } \\
\text { irrigation development and basic } \\
\text { sanitation with integrated watershed } \\
\text { approach, preservingtheenvironment, } \\
\text { which ensures priority use od water for } \\
\text { life, respecting traditions and customs } \\
\text { to livel well (MMAyA 2011). }\end{array}$ \\
\hline $\begin{array}{l}\text { Vice-Ministry of } \\
\text { Potable Water and } \\
\text { Sanitation } \\
\text { (Viceministerio de } \\
\text { Agua Potable y } \\
\text { Saniamiento Básico } \\
\text { - VMPS) }\end{array}$ & $\begin{array}{l}\text { National } \\
\text { Actors }\end{array}$ & $\begin{array}{l}\text { The object of VMPS (S.D. 29894/09) is } \\
\text { to implement driking water (potable } \\
\text { water, sanitary sewer, composting } \\
\text { toilets, solid waste and storm } \\
\text { drainage) and basic sanitation as well } \\
\text { as manage funding for investment to } \\
\text { allow full access and expantion of } \\
\text { services, particularly in rural and } \\
\text { urban sectors and peri-urban low } \\
\text { income areas, and coordinating with } \\
\text { the appropriate bodies, within the } \\
\text { integrated management of water } \\
\text { resources and solid waste. }\end{array}$ \\
\hline $\begin{array}{l}\text { Vice-Ministry of } \\
\text { Environment and } \\
\text { Climate Change } \\
\text { (Viceministerio de } \\
\text { Medio Ambiente y } \\
\text { Cambio } \\
\text { Climáticos } \\
\text { VMEBC) }\end{array}$ & $\begin{array}{l}\text { National } \\
\text { Actors }\end{array}$ & $\begin{array}{l}\text { VMEBC aims to regulate, plan and } \\
\text { oversee the integrated management of } \\
\text { natural resources and environment } \\
\text { quality in order to increase the quality } \\
\text { of life of the population. Such object } \\
\text { should be achieved within the } \\
\text { framework of sustainabledevelopment } \\
\text { under the philosophy of living well } \\
\text { while reducing poverty. }\end{array}$ \\
\hline $\begin{array}{l}\text { Vice-Ministry of } \\
\text { Water Resources } \\
\text { and Irrigation } \\
\text { (Viceministerio de } \\
\text { Recursos Hidricosy } \\
\text { Riego - VMWRI) }\end{array}$ & $\begin{array}{l}\text { National } \\
\text { Actors }\end{array}$ & $\begin{array}{l}\text { The Vice-Ministry of Water Resources } \\
\text { and Irrigation established in } 2008 \text { was } \\
\text { developed as a tool for informing the } \\
\text { management sector under the } \\
\text { National Irrigation and Watershed } \\
\text { Plan. The VMWRI has adopted an } \\
\text { integrated water resource } \\
\text { management (IWRM) plan through } \\
\text { the Bolivia's National Plan for } \\
\text { Watershed Management (Plan } \\
\text { Nacional de Cuencas - PNC, 2006). }\end{array}$ \\
\hline
\end{tabular}




\begin{tabular}{|c|c|c|c|}
\hline $\begin{array}{l}\text { National Irrigation } \\
\text { Service (Servicio } \\
\text { National de Riego - } \\
\text { SENARI) }\end{array}$ & $\begin{array}{l}\text { National } \\
\text { Actors }\end{array}$ & & $\begin{array}{l}\text { SENARI is strenghted with } \\
\text { administrative and management } \\
\text { powers and it has the responsability to } \\
\text { execute and coordinate with the } \\
\text { various bodies at national, } \\
\text { departmental, municipal, local and } \\
\text { watershed activities for the } \\
\text { development of irrigation. Moreover, } \\
\text { its duty is to regulate, plan, manage } \\
\text { and promote public investment in } \\
\text { irrigation development, agricultural } \\
\text { and forestry production. }\end{array}$ \\
\hline $\begin{array}{l}\text { Municipalities } \\
\text { (Municipios) }\end{array}$ & & $\begin{array}{l}\text { Local } \\
\text { Actors }\end{array}$ & $\begin{array}{l}\text { A set of laws (Popular Partecipation N. } \\
\text { 1551, the Municipalies Law N. 2028, } \\
\text { Law N. } 2066 \text { of Provision of Water } \\
\text { Service, Potable and Irrigation Act N. } \\
\text { 2878) states that municipal } \\
\text { governaments hold administrative } \\
\text { jurisdiction over water sanitation } \\
\text { services. According to the Law of } \\
\text { Popular Participation, Municipalities } \\
\text { are responsible for the provision, } \\
\text { operation and maintenance of water } \\
\text { services and sanitation in their } \\
\text { jurisdiction. }\end{array}$ \\
\hline $\begin{array}{l}\text { Decentralized } \\
\text { irrigators and local } \\
\text { decision-makers } \\
\text { (Regantes) }\end{array}$ & & $\begin{array}{l}\text { Local } \\
\text { Actors }\end{array}$ & $\begin{array}{l}\text { Irrigators are acknoledged as } \\
\text { legitimate partners in negotiations } \\
\text { with the State, the private sector and } \\
\text { donor agencies. }\end{array}$ \\
\hline $\begin{array}{l}\text { Ancient Indigenous } \\
\text { agreements }\end{array}$ & & $\begin{array}{l}\text { Local } \\
\text { Actors }\end{array}$ & $\begin{array}{l}\text { In indigenous zones, community } \\
\text { wateruse and management is usually } \\
\text { based on customary practicies and } \\
\text { governed by elders and traditionals } \\
\text { leaders within an Ayllu. }\end{array}$ \\
\hline
\end{tabular}

Table 6.2: main organizations in the Bolivian water management

\section{Local Actors}

Municipalities

A set of law (Popular Participation No. 1551, the Municipalities Law No. 2028, Law No. 2066 of Provision of Water Services, Potable and Irrigation Act No. 2878) states that municipal governments hold administrativejurisdiction over water and sanitation services. According to the Law of Popular Participation, municipalities are responsible for the provision, operation and maintenance of water services and sanitation in their jurisdiction.

Regantes (the decentralized irrigators and local decision-makers)

Bolivian irrigators or Regantes, decentralized irrigators come into prominence after the protests against neo-liberalization of resources mainly the 'water wars' and the 'gas wars' (Perreault 2006; Perreault 2007), have influenced the 
institutionalization and hence governance of water resources. Irrigators are acknowledged as legitimate partners in negotiations with the state, the private sector, and donor agencies. Their legitimacy arises from their successful campaign for an Irrigation Law that was passed in 2004, which critically involves them as stakeholders in - a seemingly - transparent and participatory process of water governance. In essence, the irrigator rights movement strengthen the legitimacy of civil society actors and effectively worked towards and filled the "hollowed out" state of Bolivia where, anti-neoliberal, culture-based, decentralized and interconnected network of peasants have successfully reconfigured the geometry of power and politics in natural resource governance (Perreault 2008).

\section{Ancient indigenous agreements}

In indigenous zones, community water use and management are usually based on customary practices and governed by elders and traditional leaders (Table 6.3) within an ayllu. An ayllu is a typical Andean form of extended family community region characterized by having a common -real or perceived- descent and that works collectively (called "ayni") in an area of common property (Machicado, 2012).

\begin{tabular}{|c|c|}
\hline Name & Function \\
\hline Curaca por ayllus & $\begin{array}{l}\text { He is in charge of protecting the territory and } \\
\text { knowing the population who is in charge of. }\end{array}$ \\
\hline Jilacata & $\begin{array}{l}\text { He is in charge of collecting property taxes and visits } \\
\text { the families of his ayllu. }\end{array}$ \\
\hline Corregidor & $\begin{array}{c}\text { He is responsible of ensuring the welfare and the } \\
\text { development of the Municipality as well as to enforce } \\
\text { the laws. }\end{array}$ \\
\hline Agente municipal & $\begin{array}{l}\text { He is responsible for enforcing livestock damage to } \\
\text { crops, cemetery management, rodeo donkey. }\end{array}$ \\
\hline Comisionado & $\begin{array}{l}\text { He is in charge of notifying communications for } \\
\text { assemblies, meetings, etc }\end{array}$ \\
\hline J unta escolar & $\begin{array}{c}\text { He is the responsible of watching over education issue } \\
\text { and its management. }\end{array}$ \\
\hline Registro civil & $\begin{array}{l}\text { He is the responsible of issueing birth, death and } \\
\text { marriage certificates. }\end{array}$ \\
\hline $\begin{array}{l}\text { Presidente Asociación } \\
\text { comunal }\end{array}$ & $\begin{array}{l}\text { He is in charge of maintaing communication with } \\
\text { ARCCA, AZCCA organizations and partners. }\end{array}$ \\
\hline Juez mínima cuantía & $\begin{array}{l}\text { He has the role to deal with families' requests by } \\
\text { fulfilling rules and rights. }\end{array}$ \\
\hline
\end{tabular}

Table 6.3: Description of the different roles in an Ayllu

\subsection{DECISION-MAKING AND WATER ORGANIZATIONS}

The organizations in the Bolivian water sector are multiple and complex. Decisionmaking organizations are mainly governmental institutions even though they are strongly influenced by very-active stakeholders such as societal actors, nongovernmental organizations, and donor agencies. The civil unrest following the 'water wars' and the indigenous rights movement has left an indelible institutional 
memory and is often cited by decision-makers as the pivotal moment for organisational reform, which has contributed to the organisational diversity seen in present days. Bolivia's legislation governing water is incomplete, out-dated (the National Water Law has not been revised since 1906) and falls short in clearly stating user rights. In addition, Bolivia has attempted with popular participation to create a new law to govern water resources but has been unsuccessful to date (Calvo 2006). In this context, the Ministry of Environment and Water (MEW) is one of the most powerful ministries in the Bolivian cabinet. The MEW has grown rapidly into a network of national, regional, and local entities, whose representatives have various means of providing their input to policies devised by MEW.

The Consejo Interinstitucional del Agua (CONIAG) serves as the 'forum' where MEW encourages disparate participation, thereby representing the socialist electorate and constituents of President Morales. Ministers and Vice-Ministers of MEW routinely make decisions while balancing the needs of a multitude of stakeholders. This challenge of balancing needs is frequently played out in ministerial budgets, external support, and leadership changes. Thus, decisionmaking at the ministerial level of MEW is highly political and less technical, thereby rendering decisions that are conservative, risk-averse, and dependent on the dynamics of the political landscape. The vice-ministries of MEW - VMWRI, VMEBC, VMPS and the independent irrigation agency SENARI present similar albeit nuanced differences in decision-making. The vice-ministries are implicitly hierarchical in political and socio-economic priorities as evidenced by the number of projects and budgetary allocations under each vice-ministry. However, all decision-makers acknowledge the importance of potable water and climate change issues irrespective of their hierarchal level across different ministries. Because irrigation is considered as one of the primary development goals of Bolivia and is supported by extensive financial support by internal and external agencies, VMWRI is not only crucial to external donors but also the decentralized irrigators. The decision-makers in VMWRI are thus highly visible political leaders and managers whose actions are closely followed by electorate and NGOs. The visibility of Bolivian water managers stems from several intricated connections and often-conflicting issues. Bolivian water sector plays host to several issues not uncommon in water management such as frequent problems in water supply and sanitation, powerful irrigation lobby groups and electorate, the rise of water-intensive mining activities, and exploding urban population. Visible effects of climate change in the form of receding glaciers and recent political upheaval riding on the political momentum created by the social unrest due to the commercialization of water contribute to the attention that MEW and VMWRI receive. Beisdes, the fact that water issues reflect and have become a symbol of a) indigenous rights, b) societal inequality and c) portrayal of Bolivia as a victim of developed-country emissions, critically shapes the politics of water management. The VMEBC has seen several organisational changes. Once a powerful ministry itself, the VMEBC has been reduced to a vice-ministry whose decision-making capacities are now subsumed by the MEW. Decisions in VMEBC follow technical guidelines and the Bolivian constitution.

Lastly, the Regantes or the community irrigators are part of a National Water Service (Servicio Nacional de Aguas). These institutions were formed in 2003 after a series of irrigator's workshops to raize awareness on water rights and livelihoods threatened by the privatization of natural resources during the water wars (Perreault 2006; Perreault 2007). As mentioned above, the focus of the Regantes is primarily securing peasants rights for irrigation, and drinking water and sewerage not only in rural Bolivia but also in urban areas.

The establishment of the SENARI, the SEDERI's codified under the Irrigation Law of 2004 is a result of proposals by the irrigators when they achieved 
the legal recognition and protection of their uses y costumbres for water rights and management (Perreault 2008). Decision-making amongst community managers is inclusive and representative of community needs. Typically, community meetings, which are held frequently, serve as the basis for decision- making where a community-elected Board of Directors makes decisions on water access and use. These decisions often reflect the irrigator's needs. Managers make decisions based on a) individual area under irrigation b) equity among community members, c) availability of water, and d) seasonality.

\subsection{TOWARDS A NEW WATER MANAGEMENT APPROACH}

Since the 1990s Bolivia has taken decisive steps towards the establishment of a decentralized administrative system, based on a model that claims responsibility to local demands and assign to municipalities power to take decisions and plan at the local scale. Since 1994, the number of municipal governments increased from 25 to 327, with a corresponding increase both in administrative revenue and local investment (Ruiz and Gentes 2008). Furthermore, departments have more political power in the decision-making process since the departmental prefects are elected directly by the people (Ruiz 2005). In this context, the Bolivian National Developing Programme recognizes the basin river management and the Integrated Water Resource Management (IWRM) approach as the mechanism to face water problems at the national level (Ruiz and Gentes 2008). Still, it is to promote coordinated development between water, land and related resources to maximize social and economic equity in order to guarantee the sustainability of vital ecosystems (MDP 2009). In the same period, the laws in force attribute to local governments the responsibility of water services, local sewerage, and the management of microirrigation infrastructures. Furthermore, the existing institutions identify the departmental governments (prefectures) as the key authorities to operationalize and implement environmental policies and the IWRM (Ruiz and Gentes, 2008). In this context, the National Basins Plan (Plan Nacional de Cuencas (PNC) of Bolivia approved in 2006, has been developed with the aim of the "good" governance of water resources in Bolivia (GTZ 2010) on three pillars: the Integrated Water Resources Management, Integrated Watershed Management (MIC), and the Social Management of Water and Environment in basins. These pillars are considered necessary and complementary. According to the PNC, the Integrated Watershed Management is understood as a set of actions leading to sustainable use and exploitation of natural resources of the basin. Initially, the scope of MIC was oriented towards treating water catchment areas, while today it is associated with spatial planning issues, regional development and integrated environmental management. Actions should be aimed at improving the quality of life of the inhabitants of a watershed (Cooperación Alemana 2010). The third concept that the PNC adopted is the Social Management of Water and Environment in basins. It refers to a participatory decision-making system and the implementation of new social measures related water use and management, based on a continuous development of knowledgeand learning across different social groups, which allows them to influence the processes of decision-making at the political level. Despite this, as suggested by Bellaubi and Bustamante (2018) water projects implemented within the PNC are strongly driven by geopolitical and economic interests and outcoming, in most cases, in land and water disputes between rural communities and the government.

\subsection{WATER MANAGEMENT AND THE INDIGENOUS FARMERS COMMUNITY}


The law (CPE. art. 403) a "Territorio Indigena Originario Campesino" (Original Indigenous Rural Territory) (TIOC) set the rules for: areas of production and exploitation, areas for the preservation of natural resources and areas for social spiritual and cultural reproduction. The new Constitution of the State (CPE) states the right to land to indigenous communities, the exclusive use and the exploitation of renewable natural resources according to the conditions determined by law (Fundación Tierra 2011). Furthermore, it recognizes the right to be informed, consulted and to participate in profits coming from the exploitation of nonrenewable natural resources that are in their territory. Indigenous communities have the right to apply their own rules, to be administered by their structures of representation and to define their way to develop according to their cultural criteria and principles of harmonious coexistence with nature. Moreover, social organizations (mainly indigenous and farmer organizations) managed to ensure both within the Constitution and the watering law the respect of the uses and customs of the indigenous peoples about self-determination, access to water and natural resource. From an interview with the NGO Agua Sustentable (Cochabamba, J une 2012), it becomes clear that such intention germs from the will to avoid any possible abuses of large users (industries, mining sector, companies providing municipal water), which in the past have pressured to privatize water.

The term "water rights" in the indigenous farmers' communities refers to a set of rights, which undoubtedly emphasizes the right to use and access to channels and other sources, but also the right to participate in decision-making on water management, admission of new users (e.g. migrants) and alienation of third parties (in the form of sanctions or limitations). Such right, use and access to water of family, for example, is defined by his participation in rituals, celebrations and community activities (Gerbrandy and Hoogendam 1998). Irrigation systems in Andean indigenous communities are systems of "collective action" (Boelens and Davila 1998). Access to and use of water require collective agreement and work because an isolated individual cannot manage and maintain irrigation systems efficient because of their complexity. In these irrigation systems, there are "ayllu": families who have the right to use a portion of the water and to participate in the collective decision-making process. Thus, in the indigenous farmer management, the right to water is an individual or family right within a system of collective decisions. Individuals or families can claim the use of part of the water, but they cannot decide on its use in time and space without previous arrangements with other users. Hence, water is not seen only as a natural resource because it also embeds social aspects, and therefore the water cannot be considered a private good (interview with NGO ACRA Bolivia, October 2016). Users, such as the head of the family, may have the right to participate in the making-decisions process or be elected as "Alcalde de agua" (in Spanish, water Mayor), the authority in charge of planning works of maintenance, controlling water distribution between families and holding a meeting to discuss community issues and decide sanctions, if necessary. To keep the right to access and use water, farmers must do some works, such as maintaining and cleaning canals of irrigation as well as roads that pass through their territory.

\subsection{THE WATER SYSTEM IN THE MUNICIPALITY OF TOMAVE (POTOSÍ)}

Water in the urban settlements 
Based on data collected in the Statistical Atlas of Municipalities (Atlas estadístico de municipios) (2005), in the rural area of Tomave, water to peopleliving in villages is provided by two different systems: piped distribution system delivering water to 1671 houses located in a village (44.8\%) (Figure 6.3); and "mingitores rusticos" (wells) serving 685 houses located in a village (18.3\%); people not living in villages extract water mainly from streams (36.1\%) or "ojos de agua" (springs). A new set of data contained in the 2012 National Census on Population and Housing describes, even though with less detailed as regards 2005 , the water system in the municipality of Tomave. Due to the different criteria used to collect data, it is not possible to make a comparison between the conditions in 2005 and 2012; however, the new data set confirm that two are the primary water sources used pipes and stream. Concerning the water toilet drainage, drainpipe and other system are still the most used in Tomave (Table 6.4).

\begin{tabular}{|c|c|c|c|c|c|c|c|}
\hline \multicolumn{8}{|l|}{ TOMAVE } \\
\hline Houses & Total & $\begin{array}{l}1992 \\
\text { urban }\end{array}$ & Rural & Total & $\begin{array}{l}2001 \\
\text { urban }\end{array}$ & Rural & $\begin{array}{l}2012 \\
\text { Total }\end{array}$ \\
\hline Number of Houses (Viviendas) & 4861 & 0 & 4861 & 5014 & 0 & 5014 & 6774 \\
\hline Number of Houses (Hogares) & 3150 & 0 & 3150 & 3726 & 0 & 3726 & N/A \\
\hline with kitchen and bathroom & 175 & 0 & 175 & 221 & 0 & 221 & $\mathrm{~N} / \mathrm{A}$ \\
\hline with kitchen or bathroom & 2363 & 0 & 2363 & 2877 & 0 & 2877 & N/A \\
\hline no kitchen and no bathroom & 612 & 0 & 612 & 628 & 0 & 628 & N/A \\
\hline Piped & 627 & 0 & 627 & 1671 & 0 & 1671 & 2490 \\
\hline Tank truck & 18 & 0 & 18 & 0 & 0 & 0 & 33 \\
\hline Well & 551 & 0 & 551 & 685 & 0 & 685 & 751 \\
\hline Stream ( or surface water) & 1945 & 0 & 1945 & 1346 & 0 & 1346 & 1857 \\
\hline Other & 9 & 0 & 9 & 24 & 0 & 24 & 85 \\
\hline drainpipe & 29 & 0 & 29 & 23 & 0 & 23 & 158 \\
\hline septic room & 6 & 0 & 6 & 17 & 0 & 17 & 86 \\
\hline Other & 172 & 0 & 172 & 229 & 0 & 229 & 179 \\
\hline No toilet & 2943 & 0 & 2943 & 3457 & 0 & 3457 & N/A \\
\hline
\end{tabular}

Table 6.4: Housing Conditions in Tomave (INE - Statistic Municipalities Atlas, 2005 and the 2012 National Census on Population and Housing) 


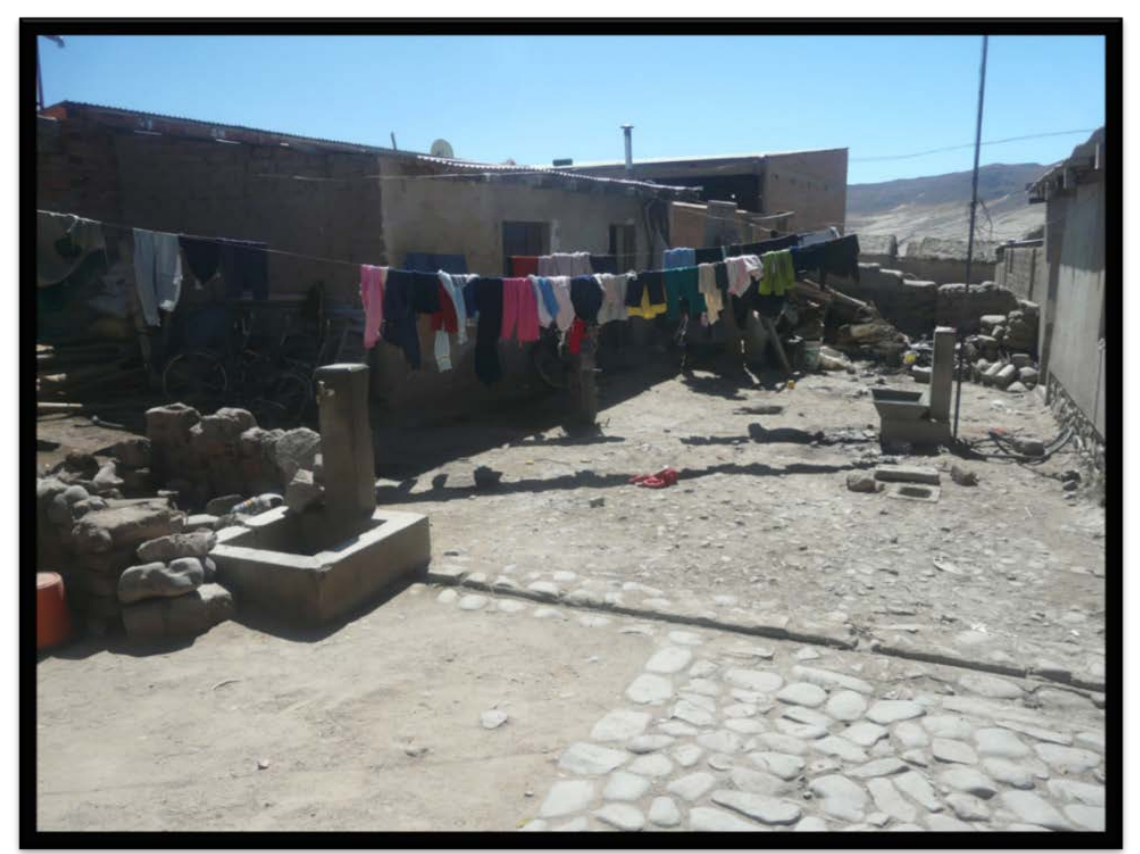

Figure 6.3: Houses and water services in Tomave (source: Author)

\section{Irrigation systems}

Users participating in the realization of irrigation works consider then an investment in terms of labour, intellectual contribution, fee, meetings, etc. The duties concerning the cleaning of water channels and maintaining the routes are directly linked supporting the development of community life, and the irrigation system too (Figure 6.4 and Figure 6.5). There is thus a close relationship between water management and the other social functions. People belonging to an indigenous community do not meet and interact only as irrigators but also, and sometimes primarily, as relatives, neighbour, coowners, etc. (interview with NGO ACRA Bolivia, October 2016). Besides, such different interrelations between users highlight the necessary flexibility required in the implementation of duties and penalties associated with noncompliance with the local legal regulations.

To grant the water right to a family or individual, the community determines whether he is meeting its duties and functions. In case a user does not comply with its obligation to clean the channel or make up for his wage or ignores the recommendations of the "Alcalde de agua", he may be sanctioned with the suspension of water, but never forever. The application of sanctions is not rigid. It depends on a collective decision, and there is considerable tolerance between members; hence failure is rare. At times and as the ultimate and final solution, if someone cannot replenish his wages or cannot be substituted by anyone, he may be authorized to cancel his duty providing the sum of 20 Bolivianos which corresponds to 2,10 $€$ (Interview had with the Curaca of El Asiento (Chikoka Chico), June 2016). Therefore, one of the fundamental principles in the Andean irrigation system is the continuous process of creation and interpretation of rights in terms of development, adaptation and rehabilitation of the system (Boelens and Davila 1998). However, such a community system of rules and agreements is currently at the stage as described in the next section due to the quinoa cropping exploitation. Analyzing in details the irrigation system, it is evident that all communities in the Municipality of Tomave use irrigation systems to crop (Table 6.5). During the fieldwork, it was possible to notice that there were several problems related to water loss or inefficient use (such as losses due to runoff, the practice of night irrigation) and 
polluted water due to mining activities.

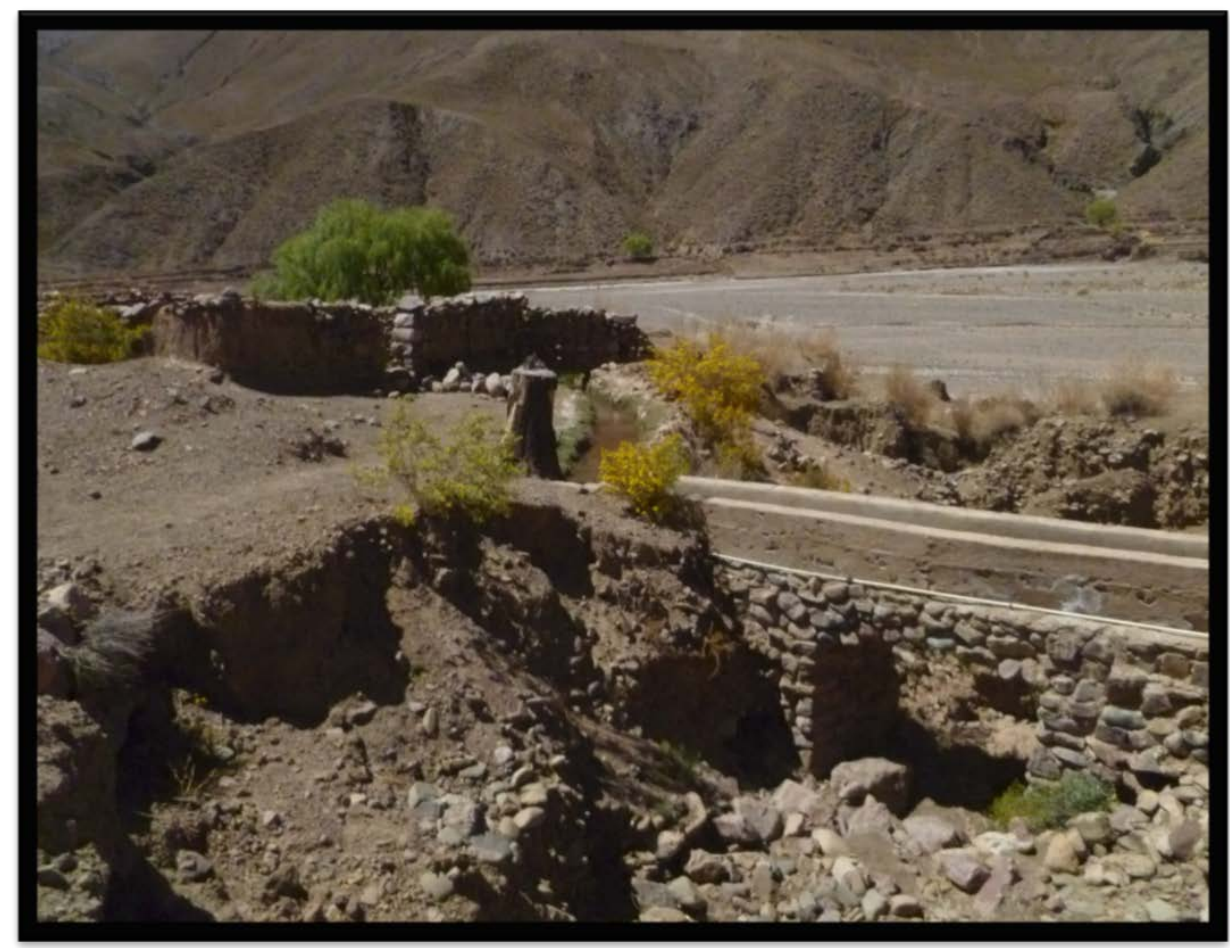

Figure 6.4: Water transfer for irrigation (source: Author)

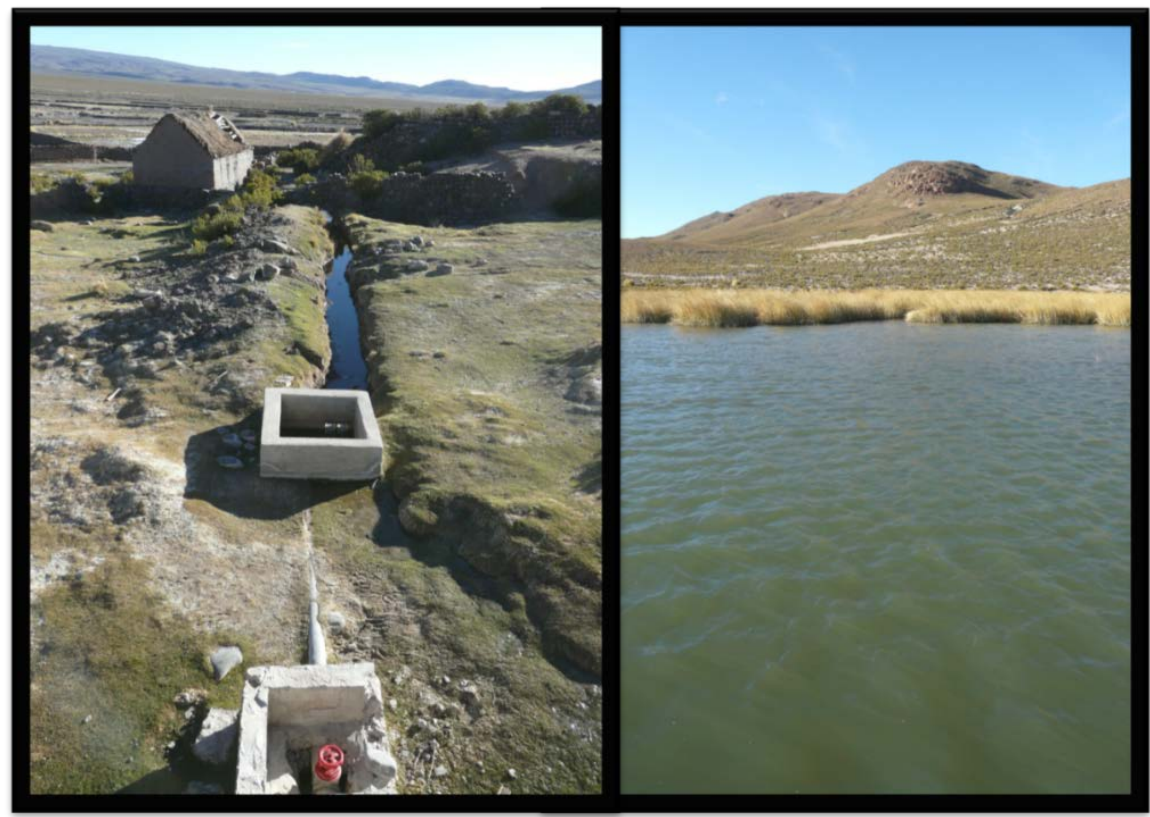

Figure 6.5: Reservoir in Tomave (source: Author) 


\begin{tabular}{|c|c|c|c|}
\hline Ayllu & $\begin{array}{l}\text { Name of } \\
\text { Community }\end{array}$ & Irrigation System & Notes \\
\hline $\begin{array}{l}\text { Chikoka } \\
\text { Chico }\end{array}$ & El Asiento & $\begin{array}{l}30 \% \text { of plots are irrigated by } \\
\text { floodplain irrigation througt } \\
\text { distribution channels, } 20 \% \text { use } \\
\text { drop-by-drop technology and } \\
50 \% \text { use a rainfed system. }\end{array}$ & $\begin{array}{l}\text { Water distribution systems } \\
\text { through open channels for } \\
\text { storage } \\
\text { distribution } \\
\text { (sprinkler). }\end{array}$ \\
\hline $\begin{array}{l}\text { Chikoka } \\
\text { Chico }\end{array}$ & Chiutaca & $\begin{array}{l}95 \% \text { of plots are irrigated by } \\
\text { floodplain irrigation throug } \\
\text { distribution channels, whereas } \\
5 \% \text { use a rainfed system }\end{array}$ & \\
\hline J ila Chico & Saruyo & & $\begin{array}{l}\text { There are dams that provide } \\
\text { water to the communities, so } \\
\text { that there are agreements for } \\
\text { cleaning and maintenance at } \\
\text { the level of Ayllu. }\end{array}$ \\
\hline J ila Chico & Uracaya & & $\begin{array}{l}\text { There are dams that provide } \\
\text { water to the communities, so } \\
\text { that there are agreements for } \\
\text { cleaning and maintenance at } \\
\text { the level of Ayllu. }\end{array}$ \\
\hline $\begin{array}{l}\text { Tawqa } \\
\text { Grande }\end{array}$ & Suntura & $\begin{array}{l}\text { The same the river supplies } \\
\text { water for irrigation }\end{array}$ & $\begin{array}{l}\text { In the area of wetland, there is } \\
\text { a thermal water spring. }\end{array}$ \\
\hline $\begin{array}{l}\text { Tawqa } \\
\text { Grande }\end{array}$ & Ventilla & $\begin{array}{l}\text { They exploit part of the river } \\
\text { flow for irrigation through } \\
\text { distribution channels. }\end{array}$ & \\
\hline Chikoka & Tomave & $\begin{array}{l}100 \% \text { of their vineyards have a } \\
\text { floodplain irrigation system } \\
\text { and water is distributed to plots } \\
\text { through channels. }\end{array}$ & $\begin{array}{l}\text { There is a moderate amount } \\
\text { of water in the groundwater } \\
\text { and emerge from springs or hot } \\
\text { springs. }\end{array}$ \\
\hline Sillsawa & Totora “K” & $\begin{array}{l}\text { Plots are irrigated through a } \\
\text { channel distribution system. }\end{array}$ & \\
\hline Aransaya & Sivingani & $\begin{array}{l}\text { Plots are irrigated through a } \\
\text { channel distribution system or } \\
\text { rainfed. }\end{array}$ & \\
\hline Q'hasa & Opoco & $\begin{array}{l}\text { Plots are irrigated through a } \\
\text { channel distribution system }\end{array}$ & \\
\hline$Q^{\prime}$ hasa & $\begin{array}{l}\text { Carlos } \\
\text { Machicao }\end{array}$ & $\begin{array}{l}\text { Plots are irrigated through a } \\
\text { channel distribution system. }\end{array}$ & \\
\hline$Q^{\prime}$ hasa & J achioco & $\begin{array}{l}\text { Plots are irrigated through a } \\
\text { channel distribution system or } \\
\text { rainfed. }\end{array}$ & $\begin{array}{l}\text { There is a lake - La Kaluta - not } \\
\text { very deep, which is in danger of } \\
\text { extinction. }\end{array}$ \\
\hline
\end{tabular}

Table 6.5: Irrigation systems used in the different communities (source: Author)

Water resources and hydropower

Activities contaminate some rivers carried upstream by the use of lubricants in hydroelectrical power generation (Kilpani Hydropower Plants, Landara and Punutuma) (PDM Tomave 2008) directly affecting the amount of availability of 
water for agriculture ${ }^{16}$ and other uses.

\subsection{MAIN TRANSFORMATIONS DUE TO THE BOLIVIAN QUINOA MARKET}

Traditionally, the cultivation of quinoa was aimed at auto-consumption (Lidema 2008), and the whole production process was conducted manually according to well-defined practices. One of these was to leave lands uncultivated for extended periods (around one year) for storing water in the soil, restoring soil fertility after harvest and reducing the probability of diseases (J offre and Acho 2008). In recent year, the market-dominated agricultural regimes pushed producers to move from cropping in the hilly territories to the plains (Balee 2003), where at the expenses of the earlier covered by vegetation areas, farmers can cultivate larger plots thanks to the mechanized production system. The current trends in the land-use changes in the municipality of Tomave are likely to trigger land degradation, jeopardizing future livelihood opportunities. Indeed, the land-use changes oriented towards the implementation of quinoa intensive mono-cropping has environmental consequences. Reduction in biodiversity, an increase in the vulnerability of the ecosystem which became more prone to the occurrence of pests and diseases affecting farmer's economy and resilience to future shocks (e.g. drought events) by either forcing farmers to use pesticides which might be expensive, or threaten the yield are some effects. Linked to the latter, a reduction in the yield is already underway since farmers cultivate their land more intensively so that they do not leave the land fallow longer like before and use a tractor with disc harrows favouring soil erosion.

The relationship between quinoa, lamas, and humans has deep roots in the past. Lamas used to take on an essentialrole since they were considered as a significant economic resource (e.g. wool and leather used by textile industries), for the communities, and the meat was used for consumption only when lamas became too old to be sold. Nowadays lamas perform a crucial role in the quinoa cropping system, where lamas' manure is extensively used to fertilize quinoa fields. Despite, there are signals of rupture in the relationship between quinoa-lama-humans. The enlargement of the cultivated plots and the consequent expansion of the agricultural frontier is determining a decrease in the fodder availability (Felix and Villa 2009), which has two main consequences as noticed during the fieldworks.

On the one hand, lamas seeking food have started to access the quinoa fields and "bofedales" (natural wetlands). Bofedales are ecosystems rich in vegetation, biodiversity, and water resources storages in the region. These areas are fragile ecosystems due to their ecological characteristics and have been recently increasingly threatened due to cattle overgrazing.

The quinoa breakout in the market has not generated only changes in the land-use changes but also transformations in social habits. As shown by the results of the European-project "Integración productiva de camélidos y quinua en Tomave (Potosí)", an increase in the farmers' annual income has been transformed on the

\footnotetext{
16 “En cuanto al municipio Tomave hay dos plantas de electrificaciones que están afectando al campesino. Más antes casi no había tanto, no se notaba, porque había nomás agua, pero en estos tiempos el agua se está disminuyendo y en ese canal donde está Chillpani y Punutuma se lo sacan todito el agua y por el río de donde tomaba el campesino no hay, no hay agua de dónde sacar. No nos da justicia tampoco nos escuchan, dos veces ya se ha levantado el campesino contra esta empresa y se va levantar siempre porque no se va a dejar así tranquilo, entonces en cuanto a estas dos empresas, en la empresa Chillpani, casi no hay sembradíos si no hay mojicales donde multiplica animales y ahí viven y ahora los mojicales se están secando no hay agua, ahora en Punutuma son sembradíos todo y se están secando, toda esa gente se iba a la Argentina, la mayoría, pero ahora están regresando como ahí la situación esta muy difícil, ahora si que necesitamos trabajar la tierra pero no hay agua" (Bustamante 2002).
} 
onehand in savings. On the other hand, increased income has been used to enhance the quality of life (e.g. improvements in house quality and purchase of more and better food), to support kids education (e.g. boarding school fees) or to increase farmers capacity to buy quinoa seeds more resistant to pests and cattle allowing farmers to access to additional labour (Vargas Ramirez 2012). On the contrary, community solidarity and participation in agricultural activities through mutual assistance (called Ayni) and collective work in agriculture or water irrigation channel maintenance and development (called Minka) as practices of community cohesion defined by the traditional community norms are disappearing provoking a loss in the social capital. A further emerging conflict concerns the growing movements of people from 9urban settlements to the rural areas during the quinoa's seeding and harvesting phases. The dynamics of this phenomenon are not easily traceable in an official manner due to the method used to collect data concerning the internal migration, which currently monitors only on three criteria (birthplace, place of residence of the last five years, and place of residence) (see Martin 2012). People, who left their native communities without having abandoned their lands, are known as residentes, while people remaining in the communities are known as estantes. Different authors (Felix and Villa 2009; Vassas Toral 2011) have already emphasis that this phenomenon is undermining, jointly with land dispossessions, traditional indigenous norms system. Indeed, according to the workshops' results, estantes were complaining about foreigners (residentes) avoiding their communal duties and neglecting Ayni and Minka norms while speculating on communities' lands (see Minucci 2018).

\subsection{BARRIERS TO A WATER MANAGEMENT PARADIGM SHIFT AND INSTITUTIONAL TRAPS}

Although nowadays the time of the "War for Water" and the social conflicts surrounding the privatization seems to be far away, Bolivia is facing today new challenges posed by the adopted water management system and discussed in section 6.11. The main concern does not refer anymore to water as a human right; it is related to the need to take measures aiming at overcoming inefficiencies due to inadequate policy and institutional frameworks, which act as barriers to the implementation of water management and the enhancement of the related decision-making processes. Regarding the new Bolivian water management, four main barriers can be identified: (1) institutional legacy; (2) fragmentation; (3) corruption and Elites pressure and; (4) lack of tools.

\section{Institutional Legacy}

The current Plan National de Cuencas (PNC) states that the basic unit of planning and management of water resources and the environment is the basin, which relates the spaces of public management and social. The basin is considered a living space, around which systems should be established integrating water resources and basin management, prioritizing human consumption, agricultural production, the needs of flora or fauna and other social practices, productive and economic (Ministerio del Agua 2006). However, as highlighted by Castrillo et al. (2006) one of the principal problems for integrated water management in Bolivia is the institutional legacy management system which is still focused on the regulation of uses for every single sector of consumption, such as agriculture, energy and domestic. The current legal framework governing water is still characterized by a large number of rules, which are contradictory and where rights are not always clearly defined. The general law regulates water resources regarding specifically the water resources, the 1906 Public Domain and Water Use Act (Ley de Dominio y Aprovechamiento de Aguas) 
(Consejo de Ministros 1906). The 1906 Act has been partially abrogated and provisions are assorted in more recent legislation, including the Environmental Act, the Mining Code, the Electricity Act, Water and Sanitation Services Law, the Irrigation Law, and the Hydrocarbons Act. Attempts to create a single law to govern water resources have been pursued but unsuccessfully to date (World Bank 2006b). One of the main achievements derived from the Water War was the Law 2066/ 2000 on Drinking Water and Sewerage (Agua Potabley Alcantarillado), which was signed with the agreement of the government and social organizations. The law aims not only to redefine the competencies regarding drinking water and basic sanitation of different entities but also to guarantee the right to water for indigenous and peasant communities and the water supply to urban slums. It assigns greater control to the Superintendency of Basic Sanitation and municipal governments. Despite this, the current government, led by Evo Morales, president of Bolivia since $22 \mathrm{~J}$ anuary 2006, intends to create a policy framework, which expressly prohibits the privatization or concession of water and its services (Ministerio de Medio Ambiente y Agua 2009). Thus through the Supreme Decree 0071/2009, the Water Supply and Sanitation Taxation and Social Control Authority (Gaceta Oficial de Bolivia, 2009) replaces the Superintendency of Basic Sanitation. Up to date, the General Water Act and the Law on Water for Life (Agua para la Vida) have not yet been approved. Therefore, the law 2066 is still in force. Furthermore, as an anticipation of the regulatory changes expected in the future, the government has changed direction where water management is concerned with the Basic Sanitation Plan 2008- 2015 (Ministerio de Medio Ambiente y Agua 2009). In addition, the National Procurement Law (1178/1990) establishes eligibility project condition that is difficult to meet for many of the local governments also because of the unclear division of responsibilities (Valle de Carvalho and Angulo 2011a).

\section{Fragmentation}

As we have seen earlier, Bolivia is promoting a shift in the context of water management by-laws and by an institutional re-organization as discussed in 6.10. Despite institutional progress, however, the same Ministry of Water doubts about the possible integration of different sectors and administrative levels arguing that "[...] the institutional framework established by different laws and regulations are not suitable to perform the Integrated Water Resource Management because there is a large number of players with powers, functions and overlapping interests" (Ministry of Water 2007, 6). There is a puzzling definition of water management roles, and/ or the formal roles are generally not followed (Agramont et al. 2019) Furthermore, the concept of water basin as defined in the PNC does not includeany socio-political element related to the water management drawing a simplicity vision of water issue. In turn, the Bolivian Constitution (in Spanish, Constitución Política del Estado) defines four types of territorial units, such as the district, the provinces, the municipalities and the original indigenous government. With reference to such division, the Law No. 031/ 2010 of Autonomies and Decentralization regulates the autonomy of each level. Autonomy is conceded both to the nine departments to regions to (all) the municipalities and to Original Indigenous Government (in Spanish, Ley Marco de Autonomías y Descentralización) except provinces. A region is not a pre-defined territory but may comprise several municipalities and provinces showing cultural and historical values as reaching an agreement on such kind of controlling system. A region may be thus constituted beyond municipalities' and/or provinces' borders, but not beyond departments' ones.

Consequently, it may happen that the administrative, political and indigenous borders do not match with the limits of the basin generating conflicts among the 
different actors involved in the water management process. As different experiences have shown it carried out the construction of a system at the institutional level to facilitate the implementation of the integrated water resource management has not been achieved yet (Quiroz et al. 2012). Besides, Agramont et al. (2019) pinpoint the fact that in Bolivia, a large portion of water resources is allocated to indigenous communities. However, at the same time, they are not included in the decision process to raise a dialogue about water governance and the effects of local development.

\section{Corruption and Elites pressure}

Corruption is a complex issue in Bolivia, and as stated by Valle de Carvalho and Angulo (2011b) and as personally experienced in some cases, it is endemic at all levels of public administration. Therefore, the inefficiency of public administration is reinforced. However, thanks the work of social organizations, the irrigation regulation and the State Constitution recognized the indigenous uses and customs (usos y costumbres) concerning self-determination, access to water and resource natural (Valle de Carvalho and Angulo 2011a). Uses and customs related to water are defined as ideas, rules and traditional practices of a community or ethnic-social group. They can be sometimes unspoken and ambiguous and justify preferential access to a source through rights, privileges (Gerbrandy and Hoogendam 1998). Although the government intention while issuing the law 2878/2004 was to prevent abuses of large users (industries, mining sector, companies providing municipal water) in the past have led to a de facto privatization of water, the constitutionalization of the customs and traditions may become counterproductive and generate more conflict if applied indiscriminately. It will have significant consequences for the ability to manage the water resources of water-related actors based on universal principles of public order and water governance. The concept of usos y costumbres is deployed discursively to claim irrigator water rights and cultural autonomy, but it also masks processes of differentiation within the Bolivian peasantry (Saldías 2012). With reference to this, irrigation can be considered a term of differentiation between farmers. In the high-altitude and semi-arid Bolivian Andes, as in case of the Municipality of Tomave here described, the irrigation serves to supplement rainfall, extend the growing season, and protect crops from frost (Guillet and Mitchell 1994). Even though no specific data exist, it is estimated that around $25 \%$ of Bolivian campesinos have access to irrigation systems (Interview with Professor Alfredo Duran Nuñez del Prado, Centro Agua, Cochabamba $19 \mathrm{~J}$ une 2016). It means that the resting $75 \%$ result more vulnerable to drought, frost, and short growing seasons using only rain-fed agriculture and experiencing higher rates of outmigration and poverty. Hence, the law 2878/2004, promoted by irrigators and their allies [mainly Feracion Departamental Cochabamba de Regantes (FEDECOR)] and the national irrigators' association], protects existing water rights but does nothing to promote the extension of rights to non-irrigating campesinos (Saldías, 2012). In addition, the law ascribes the role of referee for new water rights petitions to SENARI whose directorate is composed by seven irrigators out of the thirteen available positions (according to the article 9, law2878/2004), giving them a permanent majority. Therefore, in some respects, the law institutionalizes the privileged status of irrigators and provides the same irrigators with the power to exclude other farmers from the use of a commons resource and thus to divert investments and funds to satisfy their corporate's needs. The country holds a complex social structure with a growing power imbalance between the urban and rural areas resulting in inequalities in water allocation and water contamination, 
which often has the most significant negative impact on the most vulnerable communities (Agramont et al. 2019).

\section{Lack of tools}

Since 1994, when the Popular Participation Law" was issued, responsibilities passed to the Municipal governments and local participation addressed through the new Territorial-Based Organisations (OTB's). OTB's are recognized as a local actor in development issues, and each one is entitled to an annual fund from the local Municipality for community development projects, which they plan and submit for approval. At least $20 \%$ of national tax income is now directed to municipalities (Smits et al. 2004). According to respectively the law 2028 (Ley de Municipalidades), and the Law 031 (Ley Marco de Autonomias y decentralization), local authorities are now facing increasing responsibilities in various areas, counting for new roles relating to services delivery (like more regulatory functions), development planning and environmental management, such as the Municipal Development Plan (Plan de Desarrollo Municipal) and the Land Use Plan (Plan de Ordenamiento Territorial). These new roles constituted a major challenge, especially for rural Municipalities that before were only operating in urban centres (Smits et al. 2004). Furthermore, even though the Popular Participation Law transfers more resources to the Municipalities through the "co-participation accounts", the process of decentralization has not always entailed a transfer of human resources and management tools (Valle de Carvalho and Angulo 2011a). However, the majority of local authorities and the Municipality of Tomave is one of these, are not ready for this new responsibility due to a lack of personnel, money and political will. Therefore, while the most of the skills related to water resources management remain at the central level, the demand for "autonomy" continues to be a relevant topic in the central government agenda and it is promoted at local.

\subsection{THE ROLE OF NGO IN FOSTERING ADAPTIVE CAPACITY OF ORGANISATIONS}

ACRA Bolivia is an international medium size NGO working in different areas of Bolivia, in particular in the municipality of Tomave. In details, the NGO developed two projects ${ }^{17}$ in the area selected as a case study. The first project ended up in July 2013 while the second one in 2015. Theformer involved one thousand families, the latter down in four thousand families living in this area. They were aiming both at alleviating poverty in rural communities of the Bolivian highlands and strengthing the capacity of civil society organizations and local authorities in Bolivia (ACRA 2009; Arpaiamt 2014).

Although ACRA Bolivia's projects were not explicitly targeted to face drought and climate change, they were promoting adaptation and building adaptive capacity in the face of a complex nexus of social, economic, and environmental stressors by helping the indigenous communities to include flexible livelihood options and by facilitating the flow of knowledge and resources between local and external scales. First, ACRA had to promote among the producers, production techniques and practices respectful of the environment and appropriate to thelocal context to better face desertification and future natural disasters. Sometimes this meant recovering ancient traditional practices that have been abandoned in thelast

\footnotetext{
${ }^{17}$ Project ANE/ 2009/227-642: “Integración productiva de camélidos y quinua en Tomave” 2010 - 2012, co-financed by European Commission; Project; "Filiera Integrale per la sicurezza alimentare in Bolivia, 2013 - 2015 funded by Comune di Milano
} 
decades, such as fallow land, use of slopes oriented against the wind, etc. However, ACRA Bolivia was aware that because of changing environmental patterns, traditional knowledge could help in facing it but that alone it would not be enough. One of the outcomes of the first NGO's project was the need to equip communities with a broader array of options to face future challenges as well as a no longer quite stable environmental context. Thus, the second project was supporting the establishment of policies focused on defining production practices and rules to guarantee sustainable use of natural and productive resources (such as co-existence of agriculture and animal breeding, etc.) through a campaign of information for local producers and authorities aiming at increasing their awareness on the current problems and related future possible impacts. As we have seen, thus, organizations can foster community adaptive capacity by building flexibility into institutions and providing spaces for collective learning.

Furthermore, ACRA Bolivia actively promotes the participation of foreigner students and researchers in the project in order to bring in a variety of approaches and grasp information at other scales regarding different issues and collectively share knowledge with governmental and indigenous authorities and communities facilitating therefore cross-scale and over time interactions. ACRA Bolivia is not the only non-governmental organization working in the area. Over NGOs and international organizations carried out projects in this area in the past creating windows of opportunities four improvements at different levels, as in the case of the two ACRA's projects. Exteral organizations can support or can be a stimulus to adapt by building knowledge capacity (Azhoni et al. 2018) or by bridging the gap between researchers and policy- and decision-makers through providing or allowing them to acquire resources or to develop a favourable system for adaptation (Eisenack and Stecker 2012).

\subsection{INTERVIEWS WITH ORGANISATIONS IN CHARGE WITH WATER RESOURCES MANAGEMENT IN BOLIVIA}

Interviews with the "Curaca" of some indigenous communities, with the NGO ACRA's manager and aid-workers and with Alfredo Duran, the director of the National Study Centre on Water Management, have been carried out to understand the water management context, which the Municipality operates in (Table 6.6). These interviews were performed as open question interviews and were mostly focalised on understanding the degree of the network and the connectivity of the Municipality. Whereas, a semi-structured interview was done with the officers of the Municipality of Tomave. 


\begin{tabular}{|c|c|c|c|}
\hline \\
\hline \begin{tabular}{l|} 
No. \\
Respondents \\
from the \\
institutions
\end{tabular} & Sector & Organisations & Specific Competences \\
\hline 1 & & $\begin{array}{l}\text { Gobierno } \\
\text { Municipal } \\
\text { Tomave }\end{array}$ & $\begin{array}{l}\text { The Municipality of Tomave } \\
\text { is the second municipal section } \\
\text { of the Antonio Quijarro } \\
\text { Province in the Potosi } \\
\text { Department. This local } \\
\text { authority represents the } \\
\text { decentralization of central } \\
\text { power. } \\
\text { The municiapality develops, } \\
\text { approves, and modifies the } \\
\text { community development plan } \\
\text { according to legal norms, and } \\
\text { regional and national plans. }\end{array}$ \\
\hline 6 & Governament & Ayllus (Curaca) & $\begin{array}{l}\text { Ayllu is a typical Andean } \\
\text { form of extended family } \\
\text { community region } \\
\text { characterized by having a } \\
\text { common -real or perceived- } \\
\text { descent and that works } \\
\text { collectively in an area of } \\
\text { common property. Within the } \\
\text { ayllu, the curaca is the highest } \\
\text { authority. His power is based } \\
\text { on the ability to organize } \\
\text { people in a series of tasks. }\end{array}$ \\
\hline 1 & $\begin{array}{l}\text { Third parties } \\
\text { (NGOs, }\end{array}$ & $\begin{array}{l}\text { Centro Andino parc } \\
\text { la Gestión y Uso de } \\
\text { Agua - Universidac } \\
\text { de San Simon de } \\
\text { Cochabamba }\end{array}$ & $\begin{array}{l}\text { The Andean Centre for Water } \\
\text { Management and Use (Centro } \\
\text { AGUA) is a research and } \\
\text { educational center, belonging } \\
\text { to the Faculty of Agronomy of } \\
\text { the Universidad Mayor de San } \\
\text { Simón (Cochabamba). }\end{array}$ \\
\hline 3 & $\begin{array}{l}\text { International } \\
\text { Agency, } \\
\text { Knowledge } \\
\text { Institutes) }\end{array}$ & $\begin{array}{l}\text { ACRA-CCS Bolivia } \\
\text { (NGO) }\end{array}$ & \begin{tabular}{l|} 
ACRA Bolivia was the \\
coordinator of a cooperation \\
project aimed at reducing \\
poverty in the Municipality of \\
Tomave. Within this project, \\
ACRA recognized to its local \\
partners a key role in designing \\
and Implementing strategies \\
and actions.
\end{tabular} \\
\hline
\end{tabular}

Table 6.6: Interviews with organisations in charge of water resources management in Bolivia 


\subsection{ADAPTIVE CAPACITY OF THE MUNICIPALITY OF TOMAVE}

The municipality of Tomave manages the water resources under the umbrella of the Technical and Planning Unit (TPU). In addition to the head of the unit, an officer and a technician are in charge of managing water concerning urban and agricultural area and interacting with local water comities. For its water supply, the municipality depends on a system based on one dam, water springs, and permanent and temporary pools. However, the level maintenance of the water system is mainly inefficient, which strongly affects access to potable water, water quality, and water availability for agriculture (PDM 2008). In this section, the results of the interviews are presented, and responses to critical questions are illustrated in Table 6.7.

In the Municipality of Tomave, the Head of Technical and Planning Unit and the two officers indicate understanding the future trends in the area of Tomave as a core-theme of the municipality. Moreover, as stated by the head of TPU, access to information is seen as critical to addressing both uncertainties that are brought about by economic development and climate change. In particular, the head and the officer have the perception that the actual status of knowledge on climate change does not allow them to make sound decisions about the activities in the area in the future. Thus, they are more focused on ENSO impacts on the area, which is something they have experienced and are more familiar. From the survey, it has emerged that the ability to access data and info has increased in the last years by taking part in national and international projects and thanks to the arrival of the mobile phone technology in 2010. However, the feeling among respondents is that the current ability is far from enough, due to the low availability of historical and updated data, the lack of a structured database and capacity of data management. Besides, much information, data and knowledge are owned by the local communities and have never been recorded or collected.

The survey showed that the capacity of the Municipality to identify and fill the gaps in data and information is insufficient. Therefore, the officer and the technician started to identify and list causes and effects of the current problems to understand better what they have to face, even though as stated by the head and the officer their capacity to work with scenarios and to identify future problems is still low. The interviews highlighted that the TPU act mainly in a continuous state of emergency (low level of funds and personnel available); consequently, the need to deal first of all with daily problems reduces their capacity to tackle unexpected and future problems. According to one respondent, in opposition to this emergency status, there is the fact that by being a small group there is the need that everybody is aware of the different problems to perform different tasks at the same time. Therefore, internal communication and a shared vision of the problems are considered essential to face them off. Indeed, the survey underlines how the Municipality perceives positively the external support (e.g. the presence of national and international non-profit organizations working on technical assistance and institutional strengthening). Current projects are seen as a momentum in which they can experiment, access to information individually or collectively, even though there is a sceptical standpoint concerning the effectiveness of the solutions implemented by projects, in particular when proposed solutions are not tailored explicitly on the municipality's needs. Besides, the municipal government is generally oriented to respond to emerging problems in a reactive way entrusting to other institutions (mainly national or international) the answer shared as much as possible to the emerging problems. 
The head of TPU recognizes that dilemmas arise from the lack of coordination among the different organizations and the mayor's office. Dilemmas are due also to a low level of integration and orientation of all the implemented solutions towards a set of problems that the Municipality has currently and in the future face. On this line, the survey highlights that well-known solutions are preferred and chosen because the technicians feel more confident with them, but they would like to acquire more experience in formulating actionable and manageable solutions. As in the case of the "sub-basin water management plan", first developed but then abandoned due to long-term and sometimes-costly strategies, and hence perceived as not having clear outcomes for water resources.

The Municipality barely experiments with new solutions, and mostly all the solutions they choose are taken on the base of uncertainty or incomplete information because there are no alternatives to uncertain data as well as it might be that they do not know how to incorporate the information, such as climate information. Moreover, the current decision-making is burdened by a multitude of ambitions - indigenous, development, regional identity, and decentralized management.

As results from the interview, there is not a real monitoring process of the impacts and effectiveness of implemented solutions. However, at the municipal level, there are two phases of evaluation. The main assessment is carried out when the validity of the PDM (Plan De Desarrollo Municipal - Municipal Development Plan) ends, and the Municipality needs to draw the new plan. At this moment, a comparison of the different data describing the past and the current situation of the Municipality takes place, and it is used to orient the future goals. On the other hand, the Municipality assesses the solutions listed in the Plan de Operaciones Anual (POA) ${ }^{18}$, which are defined according to the PDM, annually. However, such assessment mainly refers to the fulfilment of expenses and fiscal requirements.

\begin{tabular}{|l|l|l|}
\hline Question & Respondent & Responses \\
\hline $\begin{array}{l}\text { To what extent is your } \\
\text { team able to access } \\
\text { data and information } \\
\text { related to future trends, } \\
\text { for instance climate } \\
\text { change? }\end{array}$ & $\begin{array}{l}\text { The head of the } \\
\text { technical and } \\
\text { planning unit/ } \\
\text { the officer }\end{array}$ & $\begin{array}{l}\text { "It is hard to say what to believe. Scientists and } \\
\text { organizations are giving conflicting advice so it is } \\
\text { difficult to do something without knowing what } \\
\text { the future will look like". }\end{array}$ \\
& & $\begin{array}{l}\text { "We increase our capacity to access information } \\
\text { in particularin the sector of agriculture and water } \\
\text { use by collaborating during projects with other } \\
\text { organizations, such as ISALP, ACRA, and } \\
\text { DANIDA. [...] working with them werealized that } \\
\text { ae do not have so many information regarding } \\
\text { the past and besides the working team is small } \\
\text { and resources are limited thus we cannot collect } \\
\text { all theinformation we would like to have from the } \\
\text { indigenous communities." }\end{array}$ \\
\hline &
\end{tabular}

\footnotetext{
${ }^{18}$ The POA is a instrument, which within the period of one year permits to intervene in the municipal economic resources in order to achieve the PDM. The municipal government can only accomplish projects and activities, which are inscribed in the POA Municipal and the PDM. Thus, the POA is an instrument for social control over the municipal governments activities and permits a transparent financial management (VPEPP, 2000).
} 


\begin{tabular}{|c|c|c|}
\hline Question & Respondent & Responses \\
\hline $\begin{array}{l}\text { How effective is your } \\
\text { team at identifying } \\
\text { gaps in available data } \\
\text { and information? How } \\
\text { effective is your team at } \\
\text { filling those identified } \\
\text { gaps? }\end{array}$ & $\begin{array}{l}\text { The officer/ the } \\
\text { technician }\end{array}$ & $\begin{array}{l}\text { We need a better understanding of cause-effects } \\
\text { relations, so we decided to sit down and work on } \\
\text { this very seriously because it has practical } \\
\text { relevance to our work [...]. } \\
\text { "We had received some training by a non- } \\
\text { governmental organization on developing } \\
\text { scenarios but there is a lot more to know } \\
\text { concerning this therefore we do not feel so } \\
\text { familiar with it." }\end{array}$ \\
\hline $\begin{array}{l}\text { How effective is your } \\
\text { team at taking a } \\
\text { proactive approach to } \\
\text { dealing with future } \\
\text { (anticipated) problems, } \\
\text { before they emerge? }\end{array}$ & $\begin{array}{l}\text { The head of the } \\
\text { technical and } \\
\text { planning unit }\end{array}$ & $\begin{array}{l}\text { "the continuing need to cope with urgent issues } \\
\text { affects the way we work; at the end of the day, we } \\
\text { have spent most of our time and resources in } \\
\text { solving only some problems." } \\
\text { "[...] to me, it seems to run after problems, such } \\
\text { as the requirements defined by the } \\
\text { administrative authority." }\end{array}$ \\
\hline $\begin{array}{l}\text { Once a problem has } \\
\text { been identified, to what } \\
\text { extent does your team } \\
\text { communicate internally } \\
\text { when defining and } \\
\text { scoping the problem? }\end{array}$ & $\begin{array}{l}\text { The head of the } \\
\text { technical and } \\
\text { planning unit/ } \\
\text { the officer }\end{array}$ & $\begin{array}{l}\text { Communication between us once we have defined } \\
\text { a problem is what reinforce our team. We want to } \\
\text { continue to communicate, surely, we should } \\
\text { spend more time in scoping a problem, but } \\
\text { unfortunately, as he said we do not have enough } \\
\text { resources and we are a small team. }\end{array}$ \\
\hline $\begin{array}{l}\text { To what extent does } \\
\text { your team seek to bring } \\
\text { in perspectives from } \\
\text { outside the institution } \\
\text { when defining and } \\
\text { scoping a problem? }\end{array}$ & The officer & $\begin{array}{l}\text { "I think that by collaborating with other } \\
\text { organizations we benefit in terms of enhancing } \\
\text { capacity to face problems and this is a valuable } \\
\text { resource we have to enlarge our perspective. } \\
\text { However, in more general terms, I think that in } \\
\text { some cases cooperation projects include actors, } \\
\text { stakeholders, like us, because they need us or they } \\
\text { need feedbacks from us, so somehow we do not } \\
\text { work together for defining problems and solving } \\
\text { them together. I think that sometimes these } \\
\text { projects develop appropriate solutions to support } \\
\text { our activities in dealing with problems and needs, } \\
\text { in someother occasion they aim only at achieving } \\
\text { their own project goals." }\end{array}$ \\
\hline $\begin{array}{l}\text { To what extent does } \\
\text { your team } \\
\text { communicate with } \\
\text { other teams in the } \\
\text { institution and with } \\
\text { other institutions when } \\
\text { defining and scoping a } \\
\text { problem? }\end{array}$ & $\begin{array}{l}\text { The head of the } \\
\text { technical and } \\
\text { planning unit }\end{array}$ & $\begin{array}{l}\text { "There have been changes in the priorities of the } \\
\text { local bodies, community and ayllus leaders } \\
\text { leading to lose of effective response and } \\
\text { leadership by stepping away from the agenda. As } \\
\text { consequence, our capacity to communicate, } \\
\text { which is, differently from our internal } \\
\text { communication, not so well developed yet has } \\
\text { further declined." }\end{array}$ \\
\hline \multirow[t]{2}{*}{$\begin{array}{l}\text { When formulating } \\
\text { potential solutions to a } \\
\text { problem, to what extent } \\
\text { does your team stick to } \\
\text { well-known, 'tried and } \\
\text { true' measures? }\end{array}$} & The officer & $\begin{array}{l}\text { "Municipal and communities authorities are } \\
\text { questioning the urgency of undertaking actions } \\
\text { on water management, thus why should we } \\
\text { change norms and practices if applying these we } \\
\text { can cope with the current situation? Therefore, } \\
\text { we have lost part of our emotional motivation for } \\
\text { action." }\end{array}$ \\
\hline & the technician & $\begin{array}{l}\text { "There was external financial support to pay } \\
\text { specifically for the plan, thus with the support of } \\
\text { the regional and international cooperation we } \\
\text { developed it. However, it does not show results in } \\
\text { the short term.", therefore, it was abandoned. }\end{array}$ \\
\hline
\end{tabular}




\begin{tabular}{|l|l|l|}
\hline Question & Respondent & Responses \\
\hline $\begin{array}{l}\text { When implementing } \\
\text { solutions, to what } \\
\text { extent does your team } \\
\text { monitor the }\end{array}$ & $\begin{array}{l}\text { The head of the } \\
\text { impacts/ effectiveness } \\
\text { of those solutions in } \\
\text { the short-term? In the } \\
\text { long-term? (different } \\
\text { response scales) }\end{array}$ & $\begin{array}{l}\text { "On one hand, the political success of the } \\
\text { government is measured a a function of the } \\
\text { resources spent, leaving less room for an } \\
\text { evaluation in terms of project quality. } \\
\text { On the one hand, there is a problem from the } \\
\text { beginning, from when solutions and projects are } \\
\text { proposed. Indeed, the law 1178 imposes } \\
\text { conditions of validity and eligibility for a project } \\
\text { that are difficult to meet for us since the current } \\
\text { process focuses more on formal and financial } \\
\text { issues, which are evaluated in-depth by the } \\
\text { administrative authority, than on the quality of } \\
\text { the proposed projects, only sometimes assessed } \\
\text { by designated authorities. Therefore, we spend, } \\
\text { unfortunately, a tremendous amount of time in } \\
\text { satisfying bureaucratic and formal requirements } \\
\text { to be funded instead of dedicate time to develop } \\
\text { the technical section of a project proposal } \\
\text { properly. As a consequence of this situation } \\
\text { imposed by the law, it is difficult for our team to } \\
\text { transform collected data and information into } \\
\text { technical knowledge for assessing the impacts of } \\
\text { proposed and current projects, also due to time } \\
\text { and resources constraints. What we do currently, } \\
\text { it is to carry out a brief assessment before } \\
\text { drawing the municipal investment plan for the } \\
\text { next year to apply for funds." }\end{array}$ \\
\hline
\end{tabular}

Table 6.7: Responses to key questions given by interviewed (source: Author)

The assessment of the organisation's adaptive capacity carried out by applying the developed framework identifies some criticalities within the operative processes of adaptive capacity in the water organization. In detail, the data collected during the interviews have been summarised and assigned respectively to the related cell of the framework (Table 6.8). The red cells refer to the absence of any activity aiming at building/ enhancing the relative capacity, while the yellow cells mean that there was an on-going activity or interest in upgrading these capacities; the green cells show that the organization already had some adaptive capacity to respond to the related dilemmas. The grey cells, instead, mean that it was not possible to collect data regarding such capacities or the amount of information collected was not sufficient to assess the organisation's adaptive capacity. 


\begin{tabular}{|c|c|c|c|c|c|c|c|c|c|c|c|c|c|}
\hline \multirow[b]{2}{*}{ What/when } & & \multicolumn{3}{|c|}{$\begin{array}{l}\text { PROBLEM } \\
\text { FINDING }\end{array}$} & \multicolumn{2}{|c|}{$\begin{array}{l}\text { PROBLEM } \\
\text { SHAPING }\end{array}$} & \multicolumn{4}{|c|}{$\begin{array}{l}\text { PROBLEM } \\
\text { SOLVING }\end{array}$} & \multicolumn{3}{|c|}{$\begin{array}{l}\text { DECISION } \\
\text { TAKING }\end{array}$} \\
\hline & & 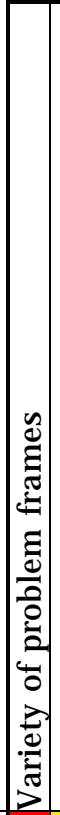 & 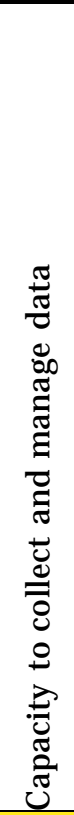 & 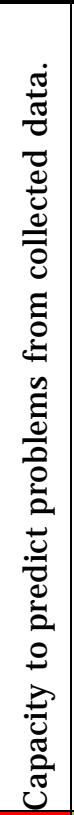 & 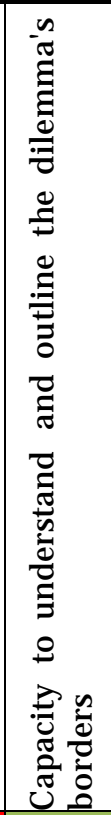 & 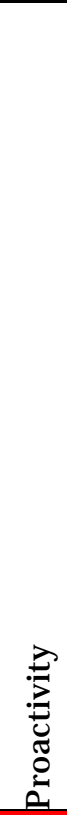 & 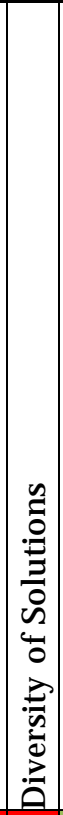 & 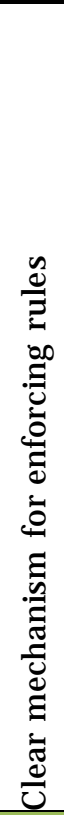 & 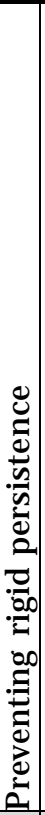 & 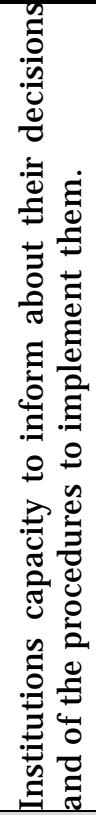 &  & 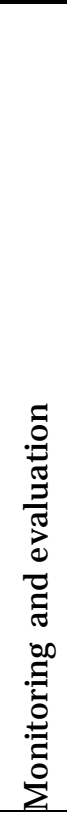 & 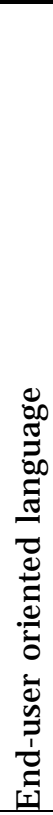 \\
\hline \multirow{7}{*}{$\begin{array}{l}\text { LEARNING } \\
\text { CAPACITY } \\
\text { (organisational) }\end{array}$} & $\begin{array}{l}\text { Ability to } \\
\text { deal with } \\
\text { everyday } \\
\text { and crisis } \\
\text { situation }\end{array}$ & & & & & & & & & & & & \\
\hline & $\begin{array}{l}\text { Willingness } \\
\text { to } \\
\text { experiment }\end{array}$ & & & & & & & & & & & & \\
\hline & $\begin{array}{l}\text { Institution } \\
\text { al memory }\end{array}$ & & & & & & & & & & & & \\
\hline & single loop & & & & & & & & & & & & \\
\hline & double loop & & & & & & & & & & & & \\
\hline & triple loop & & & & & & & & & & & & \\
\hline & Trust & & & & & & & & & & & & \\
\hline \multirow{3}{*}{$\begin{array}{l}\text { LEARNING } \\
\text { CAPACITY } \\
\text { (individual) }\end{array}$} & $\begin{array}{l}\text { Willingness } \\
\text { to change } \\
\text { and to } \\
\text { adapt }\end{array}$ & & & & & & & & & & & & \\
\hline & $\begin{array}{l}\text { Preparedne } \\
\text { ss to to } \\
\text { experiment }\end{array}$ & & & & & & & & & & & & \\
\hline & $\begin{array}{l}\text { Continous } \\
\text { access to } \\
\text { informatio } \\
\text { n }\end{array}$ & & & & & & & & & & & & \\
\hline
\end{tabular}




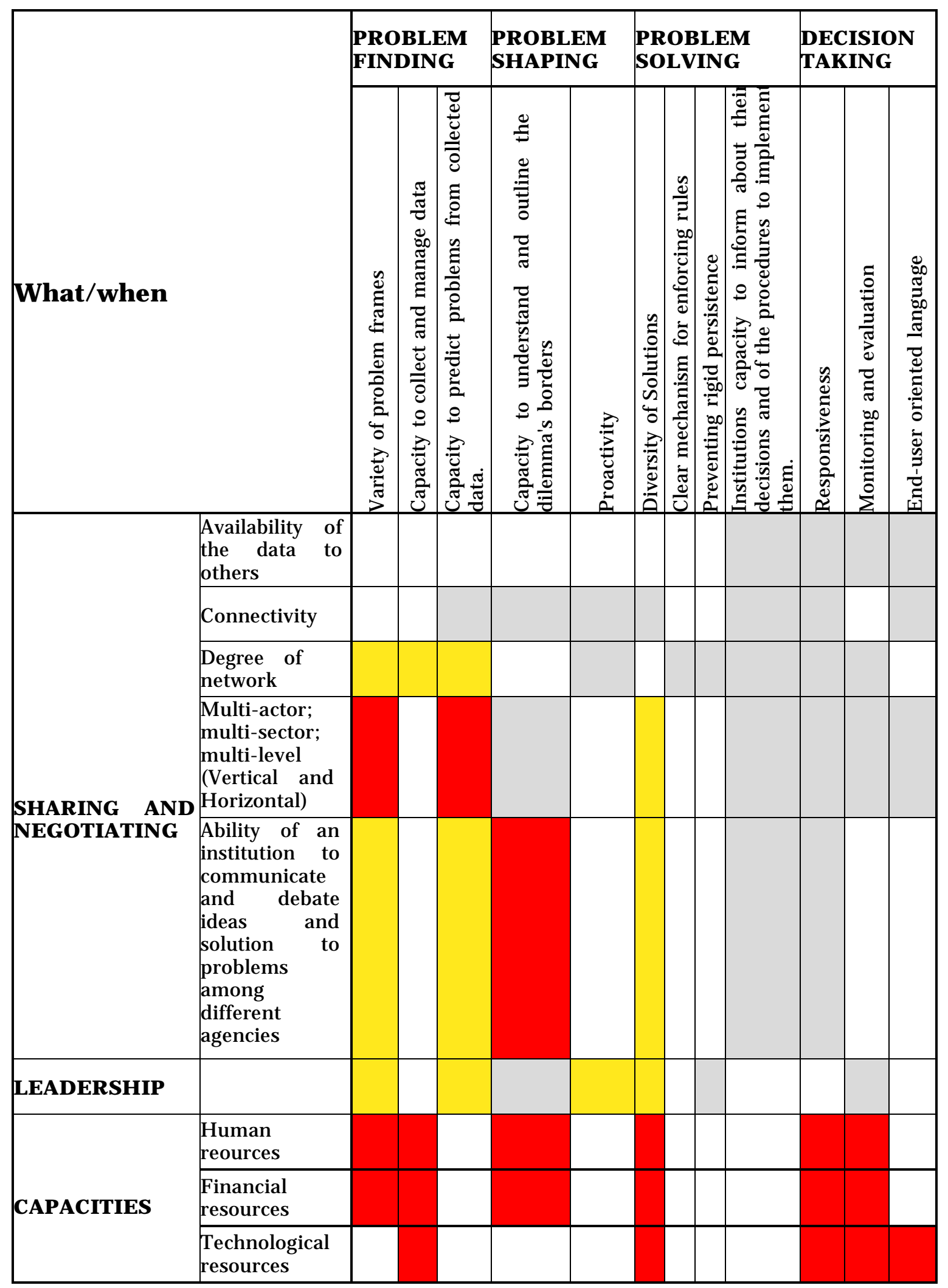

Table 6.8: Assessment of the organisational adpative capacaty of the Municipality of Tomave (source: Author) 


\section{References}

ACRA and ARCCA (2004) Diagnostico Rápido Participativo. Proyecto Camelidos Uyuni (Potosí) Bolivia

ACRA (2009) Los Actores no Estatales y las Autoridades Locales en el Desarrollo. Formulario de solicitud de subvención EuropeAid/ 127988/L/ ACT/ BO

Agramont A, Craps M, Balderrama M et al (2019) Transdisciplinary Learning Communities to Involve Vulnerable Social Groups in Solving Complex Water-Related Problems in Bolivia. Water 11(2):385

Agua Sustentable (2010) Impact of Climate Change in Andean Bolivian Communities that depend from tropical glaciers

Bellaubi F, Bustamante R (2018) Towards a New Paradigm in Water Management: Cochabamba's Water Agenda from an Ethical Approach.Geosciences 8:177

Boelens R, Dávila G (1998) Water Users' Organizations Support Approches and the Defense of Equity. In Boelens R, Dávila G (eds) Searchingfor Equity: Conceptions of Justice and Equity in Peasant Irrigation. Van Gorcum Ltdp, Assen, $\mathrm{p}$ 417-460

Bustamante R (2002) Legislación del Agua en Bolivia Centro Andino Para LaGestion Y Uso Del Agua. Centro Agua, UMSS, Cochabamba, Bolivia

Canedo Rosso C, Hochrainer-Stigler S, Pflug G et al (2018) Early warning and drought risk assessment for the Bolivian Altiplano agriculture using high resolution satellite imagery data. Nat. Hazards Earth Syst Sci 1-23

Calvo S (2006) Socially Responsible Macroeconomic Management. FretesCibils V, Giugale M, Luff C (eds) Bolivia: Public Policy Options for the Well Being of All. The World Bank, Washington, DC, USA

Castrillo L, Gaschütz G, Nippes KR (2006) Evaluación conjunta del sector de agua y saneamiento (J oint Assessment of the water and sanitation sector), European Union ASDI ACDI GTZ, La Paz, Bolivia

Fundación Fautapo, Compasur (2012) Sistema De Alerta Temprana Agrometeorológica. Boletìn Informativo Trimestral

Cooperación Alemana (2010) Experiencias De La Cooperación Alemana En El

Manejo Integral De Cuencas Y La Gestión Integral De Recursos Hídricos En Bolivia. La Paz, Bolivia

De Keizer O, HuninkJ E (2017) Dutch Risk Reduction Team Bolivia - Technical 
assistance on drought information and early warning systems. Mission Report

EarthTrends (2003) Water Resources and Freshwater Ecosystems - Bolivia EarthTrends Country Profiles series. http:// earthtrends.wri.org/ country_profiles/index.php?theme=2 (Accessed 27 May 2019).

Easterling WP, Aggarwal P, Batima K (2007) Food fibre and forest products.

In: Parry ML, Canziani OF, Palutikof JP (eds) Climate Change 200 7: Impacts Adaptation and Vulnerability. Contribution of Working Group II to the Fourth Assessment Report of the Intergovernmental Panel on Climate Change. Cambridge University Press, p 273-313.

European Commission (2007) Bolivia Country Strategy Paper 2007- 2013

Report No. E/2007/1405. Available at:

http:// www.eeas.europa.eu/bolivia/csp/07 13 en.pdf

(Accessed 15J uly 2019).

Food and Agriculture Organization (2000) Aquastat: Bolivia. http:// www.fao.org/ nr/ water/ aquastat/ countries/ bolivia/ indexesp.stm (Accessed 27 May 2019).

Félix D, Villa C (2009) Quinua y territorio. Experiencias de acompañamiento a la gestión del territorio y a la autogestión communal en la zona Intersalar del altiplano boliviano Agronomes and Vétérinaires sans frontiéres 156

Francou B, Vuille M, Wagnon P et al (2003) Tropical climate change recorded by a glacier in the central Andes during the last decades of the twentieth century: Chacaltaya Bolivia $16^{\circ} \mathrm{S}$. Journal of Geophysical Research 108:4154. doi: 10.1029/2002J D002959

Fundación Tierra 2011 Informe 2010. Territorios Indígena Originario Campesinos en Bolivia Entre la Loma Santa y la Pachamama Scorpion La Paz Bolivia.

Gaceta Oficial de Bolivia 2009 Decreto Supremo 0071 [Supreme Decree 0071] 14th of April 2009 119. Retrieved from: http:// www.gacetaoficialdebolivia.gob.bo/ edicions/view/ 119ESP.

Gerbrandy G, Hoogendam P ( 1998) Aguas y acequias. Los derechos al agua y la gestión campesina de riego en los Andes bolivianos. Centro de Información para el Desarrollo, Plural Editores, La Paz 
Government of Bolivia (2009) Constitución de la República de Bolivia Political Database of the Americas Center for Latin American Studies. Edmund A. Walsh School of Foreign Service Georgetown University, Washington DC

GTZ (2010) Experiencias de la Cooperación Alemana en el Manejo Integral de Cuencas y la Gestión Integral de Recursos Hídricos en Bolivia. Agencia Alemana de Cooperación Técnica, La Paz, Bolivia

Guillet DW, Mitchell WP (1994) Introduction: High altitude irrigation. In: Mitchell WP, Guillet D (eds) Irrigation at high altitudes: The social organization of water control systems in the Andes ed. 1-20. Society for Latin American Anthropology Publication Series 12, American Anthropological Association, Washington DC

Instituto Nacional de Estadistica, PNUD-Bolivia (2005). Atlas estadistico de municipios. La Paz, Bolivia

Instituto Nacional de Estadistica (2012) Resultados Censo Nacional de Poblacion $\mathrm{y}$ Vivienda.

Available at: $\mathrm{http}: / /$ censosbolivia.ine.gob.bo/ censofichacomunidad/

IPCC, 2014: Climate Change 2014: Impacts, Adaptation, and Vulnerability. In Field CB, Barros VR, Dokken DJ et al (eds) Part A: Global and Sectoral Aspects. Contribution of Working Group II to the Fifth Assessment Report of the Intergovernmental Panel on Climate Change Cambridge. University Press, Cambridge, United Kingdom and New York, NY, USA, p 1132

ISDR (2007) Drought Risk Reduction Framework and Practices: Contributing to the Implementation of the Hyogo Framework for Action

Joffre R Acho J (2008) Quinua descanso y tholares en el sur del Altiplano Boliviano. Revista Habitat 75:38-43

Lidema (Liga de Defensa del Medio Ambiente) (2008) Estado Ambiental de Bolivia 2007-2008. La Paz, Bolivia

Lordemann Aliaga J , Aguilar Salas TJ (2009) The Climate Change Effects on the Agricultural Sector of Bolivia. Revista Latinoamericana de Desarrollo Económico (12):7-30

Machicado J."El Ayllu" (2012)

http://jorgemachicado.blogspot.com/2012/01/am.html Access: 30 April 2019 
Martin C (2012) Migración en el Sur Boliviano. Contrastes entre valles andinos tradicionales y áreas orientales de colonización. SM gráficos, Mexico

MPD (2009) Innovacion y produccion en el Complejo Territorial Integral para el Vivir Bien. Ministerio de Planificacióndel Desarrollo, La Paz

Minelli F (2012) Communitarian water management in Bolivia: The case of Cochabamba's Comités de Agua.DADA Rivista di Antropologia postglobale II:61-72

Ministerio de Medio Ambiente y Agua (2009) Plan Nacional de Saneamiento Básico 2008- 2015. Gobierno de Bolivia, La Paz

Minucci G. (2018) Social-Ecological Implications of the Quinoa Market Teleconnections: Intervention Criteria on the Southern Bolivian Altiplano. In: Petrillo A, Bellaviti P (eds) Sustainable Urban Development and Globalization. Research for Development, Springer International Publishing

Oxfam (2009) Climate change poverty and adaptation in Bolivia Oxfam International. La Paz, Bolivia

PDM ( 2008) Plan de Desarrollo Municipal Tomave 2008 - 2012. Tomave, Bolivia

Perreault T (2006) Guerra Del Gas: Resource governance, neoliberalism and popular protest in Bolivia. Antipode 38(1):150-172

Perreault T (2007) Impasse in Bolivia: neoliberal hegemony and popular resistance. Progress in Human Geography 31(4):575-577

Perreault T (2008) Custom and Contradiction: Rural Water Governance and the Politics of Usos y Costumbres in Bolivia's Irrigators' Movement. Annals of the Association of American Geographers 98(4):834-854

Ministerio de Desarrollo Sostenible y Planificación, (2000) Primera Comunicación Nacional ante la Convención de Cambio Climático. Ministerio de Desarrollo Sostenible y Planificación y Programa Nacional de cambios climáticos, La Paz Bolivia

Ministerio de Desarrollo Sostenible y Planificación, (Programa Nacional de cambios climáticos) 2007 El Cambio Climático en Bolivia: Análisis síntesis de impactos y adaptación. Ministerio de Desarrollo Sostenible y Planificación y Programa Nacional de cambios climáticos, La Paz Bolivia Quirioz F, Delgadillo O, Duràn A (2012) Aguas arriba aguas abajo. Luces y sombras de la gestión Integral de los Recursos Hídrico: Reflexiones 
desde la investigación aplicada. Plural Editors, La Paz, Bolivia

Saldías C, Boelens R, Wegerich $\mathrm{K}$ et al (2012) Losing the watershed focus: a look at complex community-managed irrigation systems in Bolivia Water International 37(7):744-759

Ramírez E, Francou B., Ribstein P et al (2001) Small glaciers disappearing in the tropical Andes: a case study in Bolivia: the Chacaltaya glacier $16^{\circ}$. S J Glaciol 47:187-194

Ruíz SA (2005) Institutional Change and Social Conflicts over the Forest Use in the Northern Bolivian Amazon. PhD. Serie del Instituto de Política Forestal y Ambiental de la Universidad de Remagen Alemania, p 243.

Ruíz SA, Gentes IG (2008) Retos y perspectivas de la gobernanza del agua y gestión integral de recursos hídricos en Bolivia [Challenges and Foresights of Views on Water Governance and Integrated Management of Water Resources in Bolivia]. European Review of Latin American and Caribbean Studies 85:41- 59

Seth A, Thibeault J , Garcia M, Valdivia C (2010) Making sense of twenty-firstcentury climate change in the Altiplano: Observed trends and CMIP3 projections. Ann Assoc Amer Geogr 100:835-847

Balee W (2003). Participating in Development: Approaches to Indigenous Knowledge. In: Sillitoe P., Bicker A., Pottier J. (eds). Journal of Anthropological Research. 59(4):557-559

Smits S. Bustamante R. and Butterworth J. 2004 Integrated water resources management at the local level: the role of local government Centro AGUA Cochabamba Bolivia.

Stern N. 2007 The Economy of Climate Change: Stern Review Cambridge University Press.

UGRP Unidad de Gestión de Riesgos de la Gobernacion del Departamento Autonomo de Potosí (2010) Plan De Contingencia Para La Altiplano De Potosí-Bolivia. Potosí, Bolivia

USAID (2010) USAID Country Profile: Bolivia. Property Rights And Resource Governance Profile.

Valle de Carvalho M, Angulo R ( 2011a) Entidades públicas en Bolivia rehenes de consultoras y comunidades: un análisis de la gobernanza de los sistemas locales de gestión de recursos hídricos. Gobernanza 24.

Valle de Carvalho M, Haenel T (2011b) Nuevo marco legal e institucional de 
gestión: la reforma hacia una mejor gobernanza del agua. Gobernanza 22.

Vargas Ramirez R (2012) Evaluación de fin de Proyecto:Integración productiva de camélidos y quinua en Tomave (Potosí). ANE/ 2009/ 227-642

Vassas Toral A (2011) Ruralité et agriculture au prisme des mobilités spatiales. L'Altiplano Sud de la Bolivia à l'heure du boom du quinoa. Dissertation Université Paul Valéry Montpellier III

VPEPP (Viceministerio de Planificación Estratégica y Participación Popular) (2000) Elaboración Participativa del POA Municipal. Ministerio de Desarrollo Sostenibley Planificación \& Unidad Nacional de Fortalecimiento Comunitario, La Paz, Bolivia

Vuille M, Bradley R (2000) Mean annual temperature trends and their vertical structure in the tropical andes. Geophysical Research Letters 27(23):3885-3888

Water for People (2006) Bolivia Country Strategy. Submitted for consideration by the International Programs Committee 14 December. http:// ww2.waterforpeople.org/ pdfs/international/ bolivia/ BoliviaCoun tryStrategy2007-2011.pdf (Accessed 27 May 2019).

WHO, UNICEF (2004) Progress on sanitation and drinking water. Joint Monitoring Programme for Water Supply and Sanitation. New York, USA

World Bank (2004) Environment at a Glance: Bolivia. http:// siteresources.worldbank.org/INTEEI/Data/ 20784481/Bolivia.p df (Accessed 27 May 2019).

World Bank (2006) World Development Report. Equity and Development. The World Bank and Oxford University Press, New York

World Bank (2010) Adaptación al Cambio Climático: Evaluación de Vulnerabilidad y Aspectos Económicos. The World Bank, Washington DC, USA 


\section{Chapter 7: Conclusion}

Abstract. This chapter aims first to providea summary of the key insights derived as findings from the (open and semi-structured) interviews presented in the previous chapter. Data and findings from the semi-structured interviews are summarised first, and these findings are carried forward throughout this chapter. This chapter aims to revisit relevant literature to discuss the overall findings and updated conceptual framework within a contemporary context. Also presented here are the implications of the findings and limitations of the work. By means of this approach, clear contributions to knowledge this book has provided are further outlined and described.

Keywords. Adaptive capacity, Water management organisation, Barriers, Enablers, Adaptive water management, Drought risk management, drought risk

The overall aim of this book was to understand better how to enable a process of change within water management organizations to implement adaptive water management. Accordingly, this chapter discusses the research findings shedding light by taking into account contextual socio-economic and political factors on organisational and governance barriers hindering adaptive capacity, enabling adaptive organisational capacities characteristics and opportunity to empower adaptive water management to face drought risk.

\subsection{Barriers for organizations to adapt}

The results of the assessment of the organisation's adaptive capacity carried out by applying REACT highlighted several challenges. These challenges will be now discussed. The analysis aims to identify the main barrier to enable organisation's adaptive capacity, based on the description of the case study in Chapter 6, which examined and built the knowledge on the challenges that the water management of Tomave is facing. In this way, factors contributing to hinder adaptive capacity will be characterized.

\section{Learning capacity at the organization level}

The findings highlighted that the municipal technicians' team is conscious that they will have to face future droughts because they have already experienced some in the past. Nonetheless, their attitude is strongly oriented towards responding to impacts (short-term planning) rather than developing long-term measures to face them. In this regard, priorities play a crucial role. Currently, the focus is very much on response and recovery without priority to prevention and mitigation or preparing for events. Besides, even though the topic of climate change is key to the national agenda, at the local level, people are more focused on current weather conditions and disasters. The municipal technician prefers to frame discussions around extreme weather or ENSO than climate change. This is because translating the scientific and probabilistic language into scenarios that enable the organization to make management decisions and develop effective investment proposals within the terms on which the organisation is running, requires highly skilled personal and is costly. Translating and developing proposals are seen as one of the main barriers by the Municipality. The findings highlighted a gap between decisions taken at the central and even decentralised government level on the one hand and the realities of local implementation needs and capacity on the other. The case 
study showed the need to develop and enable local level capacity to interpret policy and strategy in terms of local realities and resources.

The findings showed that despite having experienced droughts, the officials of the Municipality of Tomave miss the fact that decision timescales can mean that when impacts occur, it could be too late to respond. This issue could be linked to the previous ones. Indeed, it is not only relevant to deliver useful information (and knowledge), but it is necessary to provide information in advance (so that information becomes knowledge). Nevertheless, to enable decision-makers and technicians to correctly interpret and understand information so that they are in a position to consider what it means for them and what action could be taken in their local context and circumstances. The lack of awareness and know-how with proactive and long-term decisions leads to "business as usual". In other words, when the ability or the knowledge to correctly use information lack, the Municipality tends to apply routines, rules and solutions experienced in the past. This fact contributes to making the water organisation static and vulnerable to current as well as unexpected problems. The development of a culture of monitoring and assessment of the organisational activities at all levels (internally and externally) should beinstead encouraged and implemented on a regular basis. An organisation monitors its progress in accomplishing goals (e.g. cope with current, unexpected, future problems) and assesses its effectiveness in achieving the expected results can learn and make changes coherently with the assessment results. Monitoring practices enhance the potential for gaining organisational experience. Based on the assessment results, the best organisational level to respond promptly to a problem can be identified, as discussed in section 5.2. As follows, this underlines a strong link with "leadership in the process"; indeed, leaders and champions of change may act as a boost to trigger learning loops in order to enhance or develop new routines to cope with different problems and uncertainties.

It is worth pointing out that leaders are certainly crucial in legitimising adaptation actions. However, they do not determine whether a change is successful in isolation from other factors. On this line, the Municipality of Tomave seems to reflect a growing understanding that adaptation will not be as easy to achieve as they had thought. For instance, they recognise (1) lack of skills and knowledge; (2) the need to overcome internal scepticism (about climate change as well as the goodness and benefits of some activities); and (3) lack of financial and human resources. Concerning the first two barriers, it is necessary to make a distinction between scepticism and lack of skills and knowledge. Scepticism of people (they might be leaders, decision-makers or other people who might need to change how and what they do in order to acquire adaptive capacity) refers to something that we can define as subjective. However, scepticism as other barriers that can be clustered together under the umbrella of subjective barriers, such as attitude to risk, political inclinations, etc. is difficult to measure. Nevertheless, it is crucial to understand subjective behaviours because these may lead to underinvestment in capacity development. On the other hand, skills and knowledge are different from scepticism as they can be assessed objectively.

What is resulting from the case study is that the learning process is idle. It is probably due also to the fact that there is no real monitoring and assessment of policy and programmes implemented within the organisation. Thus, the lack of these two activities implies an absence of feedbacks that may lead to a behavioural adjustment in an organisation. 


\section{Individual Learning Capacity}

The findings showed that there is the willingness to activate a process of change within the water management organization of the Municipality of Tomave, although such readiness did not convert in action yet. However, such condition clearly shows that individual change agents acknowledge the need for change, but often believe that the most effective way to advance, is through external intervention (national and/ or international). Therefore, even though there is a propensity of the municipal technicians to bend the rules, both the willingness to improve and preparedness to experiment is too low to trigger a change and have direct impacts, for instance, on the capacity to design solutions differently from those usually implemented. According to this, the lack of skills (e.g. no technical ability to identify meaningful, reliable and usable data) and knowledge (e.g., the capacity to recognize and interpret the early sign of emerging problems) can cause unexpected problems or even emergencies. Nonetheless, once such a lack is recognised, it can be tackled. However, in the case study, it was not possible to understand how far the low level of willingness to change and prepare to experiment refers to a low individual commitment or to what Gilpin and Murphy (2008) identify as pluralistic ignorance. Such type of ignorance refers to the situation in which people apply given policies or practices shared by the group even though they deem such policies/practices as not working properly, wrong or dangerous not to create dissent, believing that they are unique in their disagreement and so no sharing their opinion until such practices or policy provoke a problem.

\section{Sharing and Negotiating}

The officer is aware that external collaborations and projects are an opportunity and that it is necessary to push the Municipality of Tomave to be connected, involved, and to avoid being more isolated than they already are. Despite this, its capacity to be porous and to permit information, ideas, and perspectives from outside to find their way into the organization is still low. This explained by the attitude of donors' organisation, in fact, nowadays, also the no-profit sector has changed and requires a much stronger commitment of the Municipality to support it.Besides, cooperation projects, which commonly lasts 3-4 years, cannot solve the entire problem. Thus they should be seen by the Municipality as a tool to accomplish some tasks of a wider project lead by the local government itself. In other words, it means that the Municipality should shed new light on networking and boundary organizations, such as non-governmental organization, which can provide an opportunity for them to co-produce knowledge or gather resources. However, it is worth to note that it is not sufficient for an organisation to be open to collaborating with others, but it is needed that the former is effectively ready to collaborate and to make the best use of such collaboration. In addition, collaborating is a costly and time-consuming activity; an organisation should be aware "of what" and "to what" it wants to collaborate and thus invest the necessary resources. Directly linked to this, there is the fact that the Municipality of Tomave tens to take few decisions with extended lifetimes (e.g. ten years) as shown by the absence of any vision or long-term goal in the PDM and the POA.

Another issue refers to the inability of the Municipality to build up collaboration among indigenous communities and to create a cooperative and synergistic environment in order to support a strategy of development for the Municipality, also based on mitigation and adaptation to future risks, such as drought risk. It can be because, on the one hand, each indigenous community seeks 
its interest, creating a situation that does not favour participation nor fosters management capacity. On the other hand, the Municipality is unable to create awareness of how interdependent the single communities are and how sharing a common goal would maximize the resources the Municipality holds.

\section{Leadership}

Leaders and leadership are often considered as a critical factor in fostering adaptive capacity, in legitimizing actions to face a problem and in providing resources to deal with it.

In the case study, the Councillor legitimised the process of innovation related to the European project carried out, by the Italian NGO ACRA but he was not himself leading the change within the organisation. Instead, he delegated the technician's team manager. Although the team manager was sharing Councillor's idea, his fearfulness of making mistakes and his feeling of working in a sceptical culture, he was fostering a reactive approach. On the one hand, it confirms what stated by Peat et al. (2017) that distributed leadership to be effective necessitates that experienced staff embrace the responsibility associated with an increased leadership role. On the other hand, it supports the conclusions of Westley et al. (2013) that the rise of leadership can be profoundly dependent on the institutional context. At the same time, it highlights the relevance of leaders and of their ability to adopt diverse types of leaderships (e.g. democratic, visionary, authoritarian, etc.) to promote a change or to face problems in order to fit within the (changing) context or situation. There is the need for a transformational leader ${ }^{19}$ (see Bass 1985 and Bass and Riggio 2008). The extent to which people in charge are effective in changing their role is among the most relevant factors to build adaptive capacity. A substantial individual commitment is needed since as we have seen in paragraph 6.20, managers' task is usually to achieve the goals that are defining the agenda. Goals to be achieved, however, need to be feasible and realistic to overcome scepticism and resistance.

\subsection{Barriers to Water Governance}

Limiting the analysis to dimensions and criteria of adaptive capacity would mean to ignore other key factors, and it would be insufficient to understand why the readiness of adaptive capacity is not an assurance that mitigation and adaptation will occur. At first glance, adaptive capacity and adaptation barriers can appear as the mirror image of one another; the lack of adaptive capacity is a barrier. Nonetheless, the absence of certain factors of adaptive capacity, such as resources or information, lead to barriers their presence does not ensure that adaptation will occur (Moser and Boyoff 2013). Besides the barriers related to the capacity of an organisation to enable a process of change, such process of transformation can be restrained by political, social, economic and administrative mechanisms and

\footnotetext{
19 The concept of transformational leadership was initially introduced by J ames MacGregor Burns (1978) and later expanded by Bernard M. Bass upon Burns' original ideas to develop what is today referred to as Bass' Transformational Leadership Theory. According to Bass, transformational leadership can be defined based on the impact that it has on followers. Transformational leaders, Bass suggested garner trust, respect, and admiration from their followers. In their contribution "Transformational Leadership", Bass and Riggio (2008) explained: Transformational leaders are those who stimulate and inspire followers to both achieve extraordinary outcomes and, in the process, develop their own leadership capacity. Transformational leaders help followers grow and develop into leaders by responding to individual followers' needs by empowering them and by aligning the objectives and goals of the individual followers, the leader, the group, and the larger organization.
} 
institutions influencing the water management. Indeed, such a wide range of interests related to water resources cause numerous and significant externalities in many realms that are critical for development. Therefore, water policy needs to face a high degree of complexity, given the multiplicity of actors, motivations and stakes (OECD 2011). It raises critical considerations for effective governance.

More effective water governance is needed in order to respond to uncertainty and increasing scarcity, and improve the linkages between ecosystems through which water and social systems interact (Folke 2003). According to this, as discussed in section 4.1, effective water governance must encourage participation in the process for deciding how water is used to promote innovation and learning among stakeholders and foster adaptation to changes in water availability (Currie-Alder et al. 2006).

Being adaptation context-specific, the regional context influences how water governance is perceived and structured locally as well as it determines what can be done. Such geographical boarders should not be considered as a limitation per se. On the contrary, they give us the chance to understand better the concept of adaptive governance as well as how and why barriers are built up. The implementation of effective water governance and the scope to improve it are relevant topics in the political agenda; however, barriers to achieving it can be recognized.

Within the case study, it was possible to identify five barriers that seem to hamper the achievement of the full range of benefits foreseen by the AWM approach changes: (1) institutional legacy; (2) fragmentation; (3) lack of tools; (4) corruption and elite pressure.

\section{Institutional Legacy}

The lack of national modern water law in Bolivia creates a condition in which water resource is governed by the focus on the regulation of uses for every single sector of consumption (e.g. agriculture, energy and domestic). As a result, different ministries and public agencies are involved in water policy because of the interconnectedness of different issues (agriculture, energy, etc.). Thus, it produces a fragmented policy with the inherent risks that the "silo" approaches become real due to the absence of inter-ministerial coordination. We remind here that a silo approach is the lack of collaboration and standardization between business units, department or sectors. Thus, adopting a systemic approach in order to overcome the sectorial fragmentation of water-related tasks across the different regulators is necessary.

The institutional framework should be analysed for two specific reasons. On the one hand, it is useless to prioritize water users since rights are not always clearly defined; and, on the other hand, such institutional framework is the main reason for the disjuncture between water policies and planning. Consequently, it is still characterised by a large number of rules, which are contradictory, to the effects on the quality and quantity of water. Therefore, as highlighted by the work "Water Governance in OECD Countries: A Multi-Level Approach" carried out by the OECD (2011), coordination and consultation mechanisms must be developed to overcome the barriers to effective implementation on the ground, which implies managing the explicit or implicit sharing of policy-making authority, responsibility, development and implementation at different administrative and territorial levels. These mechanisms emphasise how an institutional framework characterized by a sectorial regulation does not fit within complex and interacting social-ecological systems. Furthermore, they underline the role played by an institutional legacy in restraining the processes of transformations and highlight 
that a more adaptive and flexible framework should put in place in order to face the challenges posed by future droughts and climate change.

In turn, the Bolivian law 2878/ 2004 was issued to prevent abuses of large users (industries, mining sector, companies providing municipal water but also because of the elite pressure of irrigation farmers association, who will continue defending its rights 41 , shows how a law with its strong regulatory impact can be the cause of a rigid and unequal water management system. As a consequence, stakeholders seek to assert control over water in order to protect their values and interest. Polycentric participation (multiple organizations and stakeholders involvement) would be needed instead of in order to determine how water is used at different levels and time. Kurachi et al. (2006) claim that equity includes, but is not limited to, equal provision of resources; fair disclosure of information; distribution among stakeholders of profits derived from natural resources, etc. Corbera et al. (2007) haveindicated that equity lies in access, decision-making and outcomes.

\section{Fragmentation}

The Bolivian case study shows how the multiplicity of services and agencies combined with the unclear or conflictual definition of power and functions have hindered efficient decision-making. Besides, the multiplicity of actors generates the inability to place responsibility and accountability in the hand of a coordinating actor resulting, therefore, in water governance failures. Consequently, the improvement in coordination between and within levels of governments is critically needed, to avoid generating a muddy system but instead to the benefit of the overlapping and redundant institutions, which may increase the capacity of a system to provide more articulated responses to a problem (Walker and Salt 2006). Therefore, as Saleth and Dinar (2000) state, a balance between centralization and decentralization to carefully craft institutional arrangements are needed at different levels to achieve both local flexibility and regional coordination.

The current system does not enable a clear and effective knowledge sharing mechanism; therefore, changes are desirable to implement a network approach and must include coincidence of goals, time scale, and monitoring. The Bolivian law 2878/2004, recognising indigenous usos y costumbres for water rights and management, create a window of opportunity to integrate not only different knowledge but to realise through hybrid pathways based on collaboration and participation a new water governance regime. With reference to this, Concilio (2000) highlights that participatory decision-making should be seen as a process of collective exploration of the decision space. Therefore, participation has to be an action-oriented process and is described as a search process looking for negotiation opportunities enabling participatory decision-making (Celino and Concilio 2011). Hence, together with progress in coordination within levels of government, heightened public exposure of bureaucratic processes is crucial since it can promote the construction of more transparent water governance (Adhikari and Tarkowski 2013) favouring information sharing and fostering participation and reducing the room for corruption.

\section{Lack of tools}

In Bolivia, the laws in force attribute the responsibility of water services and the management of micro-irrigation infrastructures to local governments. However, the process of decentralization in the Municipality of Tomave is held back because 
the Municipality has not developed or lack the needed competences, as well as the required financial and human resources, to carry out the newly assigned tasks.

\section{Corruption and Elite pressure}

Among barriers, corruption (and in some way elite pressure) presents different features if compared with the other factors. Regarding the two case studies, corruption can be considered a product indeed, and a producer of the other barriers since fragmentation as well as the absence of transparency, public participation, and legitimacy in governance creates a fertile context for corruption. Corruption, as stated by Banda (2002), can be identified as an emerging threat to equitable and sustainable development. Corruption and elite pressure are a widespread phenomenon in the two case studies (as well as in many other countries), and thus more attention should be put on it, as it threatens efficient water governance and by association, water allocation. Even though more research should be carried out regarding the impacts of corruption in the water field in the two countries, it is possible to state here that in order to suppress this phenomenon actions are required at both the policy and (formal and informal) institutional tiers. Moreover, it must be recognized that reforms will time, and considerable political will is needed to implement them.

\subsection{Opportunities to Adaptive Water Management Implementation}

At this time, the Municipality of Tomave is experiencing critical challenges posed by the social-ecological transformation in a region already prone to drought and higher risks (e.g. climate change). Although the organisation's adaptive capacity is currently low, the municipality can still create opportunities to implement adaptive water management and cope with these challenges. Not all necessary reforms can be done at the same time. It is essential to define priorities and a sequence of activities to fulfil those priorities. According to this, Lee (1993) writes that institutional and organisational challenges may be a critical barrier to the implementation of adaptive management, but at the same time that an adaptive management approach may be a tool for enhancing institutional and organisational effectiveness. As follows, even though there is a low level of adaptive capacity and changes have not been implemented yet, the Municipality of Tomave acknowledges that they need to advance. The opportunity for the implementation of adaptive water management in the Municipality of Tomave is paradoxically provided by the failure of the water management mechanism to meet the many challenges described in section 6.13 .

Within this context, adopting an alternative water management system would probably have a twofold meaning. On the one hand, the enhancement the level of coordination and cooperation between the municipal government and the other vertical and horizontal governmental institutions as well as between the Municipality and other organisations, such as non-governmental organisations, working in the region. On the other hand, the increase of the coordination and cooperation between the Municipality, as the core node of a local network, and the different indigenous communities. Considering that, enhancing cooperation and coordination can create a window of opportunity to (1) increase the level of participation in the decision-making process involving standpoints more oriented towards a long-term perspective, such as those of younger generations and; (2) design a shared vision of changing the needed path of and according to this implement the defined actions, thus reducing trade-offs and conflicts. Concerning 
this, generating a vision should facilitate consensus and commitment within the organisation itself and among all stakeholders. Moreover, defining and having a broad consensus in goals and values would guide organisational change. Since that and given the current environmental change occurring in this area, it would be necessary to take a problem-focused approach, which means considering droughts and water-related problems not as sectoral issue, but rather working at the boundaries among system and organisations. It would attach the reform processing to the need to solve a real problem. Such an approach may help to mobilize people and organizations around common goals giving them theincentive to participate in reform processes and enact changes. In addition, this would keep reforms pragmatic and action-oriented sweeping reforms and designed solutions that are not implementable, as in the case of the sub-basin water management plan.

The activation of a "process of consultations" would favour the integration between indigenous and "expert" knowledge, increasing therefore not only the data available about water but also generating wisdom ${ }^{20}$. Indeed, introducing new institutions based on generalized principles may be rejected by local people as costly, illegitimate and awkward (Cleaver 2002). Furthermore, Merrey and Cook (2012) underline how traditional or indigenous institutional measures should not be idealized either because such arrangements are "often highly inequitable (for example disempowering women), unable to adapt to rapidly changing conditions driven by population growth, climate change and new technologies, and may also be losing legitimacy because of growing ineffectiveness". With reference to this, it is worth noting that participation can marginalize the poor or vulnerable (e.g. women) even further if the mechanisms are backed by a stronger, such as richer, an advocacy group. Furthermore, the process of consultation would enable learning by doing and thus facilitate organisational learning in contrast to routine practice. In this line, for instance, water policies now focusing only on blue water can be integrated with policies oriented to the use of the green-water 25 resources, which is part of the traditional indigenous agricultural practices to crop quinoa in this area. In addition, the process of integration of knowledge would allow the Municipality not only to learn but also to take the risk of making mistakes and would foster the stakeholders' sense of ownership in the needed changes. Such ownership is essential for sustainability.

Moreover, as we have seen in paragraph 6.21, new technologies (mobile phones) are giving further chances to get more information, in the meantime, further significant opportunities can come through other technological resources, such as the internet, and pave the way to build up a network of municipalities aiming at data exchange, experiences, and advice. Networks are indeed instrumental in developing a shared understanding of a problem and aid in the formation of common objectives by defining the discourse (Raustalia 1997), and by leading on learning and the development of innovative ideas (Sendzimir et al. 2007; Pahl-Wostl et al. 2010). Besides this, the implementation of adaptive water management has to envisage also the integration of water and land use regulations especially regarding the bofedales system (see paragraph 6.15) because of the strategic role that these wetlands play in this region during dry periods. As follows, there is the need to redefine or develop new community sanctions and the way these are enforced since the current regulations are scarcely effective.

\footnotetext{
${ }^{20}$ Wisdom refers to Data-Information-Knowledge-Wisdom (DIKW) Hierarchy (Cleveland 1982), considered as the canon of information science and knowledge management. In the water sector, the Global Water Partnership refers to wisdom as agreement about commonly accepted methods of using water resources to ensure sustainability. (www.gwp.org/ en/ToolBox/TOOLS).
} 
Another bridging factor in the implementation of adaptive water management is leadership. The findings confirming the results of previous researches (Olsson et al. 2006; Engle 2012; Westley et al. 2013) highlighted that various forms of leadership are required to exploit opportunities, garner resources and support, and maintain direction and momentum. The leadership profile shown by the Councillor promoted an opportunity to implement adaptive management by collaborating with a non-governmental organization. However, the municipal officer was not a champion too. Therefore, leadership to be effectively a bridging factor needs to be transformative and embraced by relevant actors. Being aware that actors (individual and organisational) are unlikely to risk professional reputations to promote for change or champion alternatives, or are merely unable to (Bettini et al. 2015).

\subsection{Enabling Adaptive Water Management to face current and future drought risk}

Many barriers will make adaptive water management less efficient or less effective or may entail onerous changes leading to missed opportunities or higher costs. However, many barriers can be avoided or crossed by recognising the importance of sharing information, co-operating with organisations, experts and authorities and by having plans in place. As Adger et al. (2009) argue, many seeming limits, especially social ones, are malleable barriers; they can be overcome with sufficient political will, social support, resources and effort. Regarding the barrier of the financial resources to adopt risk-based drought preparedness plans and policies which is always indicated as an impediment to changing the paradigm by policy and other decision-makers, Wilhite and Pulwarty (2017) suggest, for instance, to divert resources from reactive response programs to a more proactive, risk-based management approach.

Adaptive water management, disaster risk management, and climate change adaption have to be brought together to manage water-related risks in a changing climate (Doll et al. 2015). Following this, adaptive water management should not be operationalised in a stand-alone manner, given climate change and the water-energy-food nexus. However, it must contribute and lead up to achieve sustainable development (which should also be a governmental priority). Integrating water and drought management at the basin level should be done based on a twofold perspective, water management should promote policies that endorse full protection of watersheds, and the drought management plans should include the strengthening of water management capacities within the local and regional water users and managers. Adaptive water management strategies executed before droughts arise will likely lessen the necessity for emergency response by reducing vulnerability. For instance, combining adaptive water solutions (e.g. reducing water demand or climate-sensitive water allocations) with drought early warning system could encourage more effective water and drought management actions. Given the slow onset and persistent nature of drought, water management to reduce exposure and vulnerability to water-related hazards as well as mitigating and adapting to potential impacts must be seen as an integral part of development planning and implemented at all governmental levels.

Transferring the concept of pivot firms proposed by Gilly et al. (2014) within the water management domain, according to which a pivot firms in its most highlydeveloped form represent an organisational structure which facilitates the circulation and above all production of knowledge, know-how and technologies at the territorial level. Positioned at the crossroad of technology, policy 
implementation, and public service delivery, water management organizations can play a pivotal role in enabling adaptive water management and support planning for adaptation by involving stakeholders, redesigning the planning processes, coordinating the management of land and water resources, identifying linkages between water quantity and quality, and protecting and restoring natural systems. To do so and to cope with the uncertainties of future climate and societal development, water management organizations need to have just enough flexibility (Olsson et al. 2006), balancing between innovation and reliability.

\subsection{Conclusion}

Drought is one of the most complex and severe weather-related natural disasters (Vogt et al. 2018) A drought has low visibility and, in contrast to other hazards (i.e. floods, hurricanes, etc.), deals with something which is not there. The lack of visibility and slow development makeit difficult to raise support compared to other natural hazards. Drought is thus a major issue for water management. Besides, droughts jointly with the anthropogenic climate change and its worsening hazards effects as well as the trade-offs related to the water-energy-food nexus have made water management more difficult as hydrological conditions will change in the future in a highly uncertain way.

The approach in which the water resource is currently managed affects the vulnerability of the system to face a period of drought. Indeed, drought is not only an issue related to a reduction, delay or absence of rainfall/precipitation but is also related to failures in water management (e.g. exploiting water resources, enhancing only the water supply or impeding knowledge flows). This book argued that there is the need to change the current water management approach towards adaptive water management capable of coping with societal development, weather-related risks (e.g. droughts) and uncertainties of future climate.

Therefore, there is a close link between drought risk management and water management, which determines the vulnerability of different systems to the onset of a drought event by conditioning their exposure, sensitivity, and ability to adapt. However, such link between drought risk management and water management needs to strengthen and activated as much as possible in the pre-event phase because when droughts occur all resources are put in place to the lessening or limitation of the adverse impacts of drought and related disasters. In this sense, medium- and longer-term (and thus advance) preparations to minimize impacts can fall in the domain of adaptive water management. Successful water management under the uncertain climate conditions needs organizations able to adapt in order to enable or support society to be resilient and to adapt to the drought risk and climate. An organization may also maladapt and therefore create unplanned and unforeseen vulnerabilities (Adger and Barnett 2009).

Despite the critics the adaptive water management has received, this book tries to understand better how to enable a process of change within water organisations to implement adaptive water management. The work made a case for expanding organisation's adaptive capacity and improving upon previous assessment efforts by bringing together insights from business, organisational behaviour, and climate change context. It showed that adaptive capacity is mostly seen as a black box and that ways to operationalize it are not clearly expressed.

The book outlines a framework, named REACT, for improving organisation's adaptive capacity assessment.

The REACT framework provides a set of capacities that water organisations should have to enable a process of adaptation and/ or transformation of organisational 
routines and shows how those capacities could be operationalized along the management process to build organisation's adaptive capacity to face current, future and unforeseen problems due to droughts and climate change. It allows for expansion and inclusion of new ideas in the future if that is needed. Besides, using traffic light colours allow presenting the result of the assessment communicatively. The framework has been applied to analyse and interpret the solutions adopted for water management in Bolivia. Finally, the book contributes to a better understanding of what are the barriers in the water management and governance context hampering the implementation of adaptive water management, the relationship between the various determinants of adaptive capacity and thevarious types of barriers and to analyse opportunities to overcome such barriers.

The research highlighted that promoting cooperation and collaboration with organizations, networks of organizations and communities could create opportunities to implement adaptive water management. Despite the fragmentation in the water governance, more participation and interaction could create more significant benefits for the municipality' performances regarding technical, socio-economic and environmental challenges. The implementation of adaptive water management would be an essential step for the Municipality of Tomave to cope with drought risk and climate change as well as to deal with the unsustainable transformations of the local social-ecological system due to the flourishing of the global quinoa market.

To conclude, this book wants to emphasis how in principle and practice, an adaptive approach to water management integrating drought risk (and more in general weather-related risk in a changing climate) management requires and facilitates a context with flexible and open water management organisations, on the one hand. On the other hand, it requires and facilitates governance systems that allow for learning and increase adaptive capacity to embrace climate and nonclimatic drivers uncertainties in decision-making and design solutions that reduce vulnerability to ensure sustainable development. Numerous arguments lead to the conclusion that adaptive and integrated water management is essential in order to guarantee sustainable management of the world's water resources. Therefore, it is important not to focus on developing and analysing models for an optimal integrated and adaptive water management regime, but, as this book tries to achieve, to focus on how to initiate processes of change to get there (Pahl-Wostl 2008).

\section{References}

Adger WN, Dessai S, Goulden M. et al (2009) Are there social limits to adaptation to climate change? Clim Change. 2009; 93:335- 354

Adger WN, Barnett J (2009) Four Reasons for Concern about Adaptation to Climate Change. Environment and Planning A: Economy and Space, 41(12):2800- 2805

Adhikari B, Tarkowski J. (2013) Examining Water Governance: A New Institutional Approach. J Geogr Nat Disast S 5

Azhoni A, Jude S, Holman I (2018) Adapting to climate change by water management organisations: Enablers and barriers. J ournal of Hydrology 559:736-748 
Banda F (2002) Governance and Corruption. In: Bigg T (ed) The Future is Now Vol. 3: Emerging Challenges for the Indonesia, London: IIED, p 92-98 Bass BM (1985) Leadership and Performance, N.Y. Free Press

Bass BM, Riggio RE (2008) PHD Transformational Leadership. Lawrence Erlbaum Associates Inc, Mahwah, NewJ ersey

Bettini Y, Brown RR, De Haan FJ (2015) Exploring institutional adaptive capacity in practice: examining water governance adaptation in Australia. Ecology and Society 20(1):47

Celino A, Concilio G (2011) Explorative Nature of Negotiation in Participatory Decision Making for Sustainability. Group Decis Negot 20:255.

Cleaver F (2002) Reinventing institutions: Bricolage and the social embeddedness of natural resource management. The European J ournal of Development Research 14(2):11-30

Concilio G (2000) Le valutazioni multicriteri. Strumenti per l'Apprendimentonei Processi Decisionali. Urbanistica 113:137-143

Corbera E, Kosoy N, Tuna MM (2007) Equity implications of marketing ecosystem services in protected areas and rural communities: Case studies from Meso-America. Global Environmental Change 17(3-4):365380

Currie-Alder B, Thompson L, Bustamante R (2006) Insights on Water Governance: Research in the Middle East/North Africa and Latin America. Presented at Survival of the Commons: Mounting Challenges and New Realities, the Eleventh Conference of the International Association for the Study of Common Property, Bali, Indonesia, 19-23 June, 2006

Döll P, J iménez Cisneros B, Oki T et al (2015) Integrating risks of climate change into water management. J Hydrol Sci 60(1):3- 14

Eisenack K, Stecker R (2012) A Framework for Analyzing Climate Change Adaptations as Actions. Mitigation and Adaptation Strategies for Global Change 17:243-260

Engle NL (2012) Adaptation bridges and barriers in water planning and management: insight from recent extreme droughts in Arizona and Georgia. J ournal of the American Water Resources Association 48(6):1139- 1150

Folke C (2003) Social-ecological resilience and behavioural responses. In: Biel 
A, Hasson B, Maetensson M (eds) Individual and Structural Determinants of Environmental Practice, Ashgate Publishers, London, p 226-287

Gilly J, Kechidi M, Talbot D (2014) Resilience of organisations and territories: The role of pivot firms. European Management J ournal 32(4):596-602 Gilpin DR, Murphy PJ (2008) The complexity of information and assimilation knowledge and ignorance. Oxford University Press, Oxford

Lee KN ( 1993) Greed, Scale Mismatch, and Learning. Ecological Applications 3(4):560-564

Merrey DJ , Cook S (2012) Fostering institutional creativity at multiple levels: Towards facilitated institutional bricolaje. Water Alternatives 5(1):1-19 Moser SC, Boykoff MT (2013). Successful adaptation to climate change: linking science and policy in a rapidly changing world. Routledge, London \&New York doi: 10.1016/j.gloenvcha.2004.12.005

OECD (2011) Water Governance in OECD Countries: A Multi-level Approach. OECD Studies on Water, OECD Publishing

Olsson P, Gunderson LH, Carpenter SR et al (2006) Shooting the rapids: Navigating transitions to adaptive governance of social-ecological systems. Ecology and Society 11(1):18

Pahl-Wostl C, Kabat P, Möltgen J (eds) (2008) Adaptive and Integrated Water Management: Coping with Complexity and Uncertainty. Springer-Verlag, Berlin, Heidelberg

Pahl-Wostl C, Holtz G, Kastens B et al (2010) Analyzing complex water governance regimes: the Management and Transition Framework. Environmental Science and policy 13:571-581

Peat M, Moon K, Dyer F, Johnson W, Nichols SJ (2017) Creating institutional flexibility for adaptive water management: insights from two management agencies. J Environ Manage 202:188- 197

Saleth RM, Dinar A (2000) Institutional changes in global water sector: trends, patterns, and implications. Water Policy 2:175-199

Sendzimir J , Magnuszewski P, Flachner Z et al (2007) Assessing the resilience of a river management regime: informal learning in a shadow network in the Tisza River Basin. Ecology and Society 13(1):11

Vogt JV, Naumann G, Masante D et al (2018) Drought Risk Assessment. A conceptual Framework. EUR 29464 EN, Publications Office of the 
European Union, Luxembourg, 2018

Walker BH, Salt D (2006) Resilience Thinking: Sustaining Ecosystems and

People in a Changing World. Island Press, Washington, DC, USA

Westley FR, Tjornbo O, Schultz L et al (2013) A theory of transformative agency

in linked social-ecological systems. Ecology and Society 18(3):27

Wilhite D, Pulwarty RS (eds) (2017) Drought and Water Crises: Integrating Science, Management, and Policy. Second Edition, CRC Press 


\section{QUESTIONNAIRE}

\section{Notes:}

All questions scored from 1-5:

- For 'how effective' questions, $1=$ not effective, $5=$ very effective

- For 'to what extent' questions, $1=$ never, 5 = routinely

\section{Overall}

- Name of the institution:

- Role of the interviewed within the organization:

How effective is your organization at addressing future problems before they emerge?

How effective is your organization at addressing unexpected problems when they emerge?

\section{Identifying a problem}

To what extent does your organization seek to understand future trends in your area of work?
1
2
3
4 5

To what extent is your organization able to access data and information related to future trends?

1

2

3

4 5

How effective is your organization at identifying gaps in available data and information? How effective is your organization at filling those identified gaps? 
How effective is your organization at recognising early signs of emerging problems and identifying unexpected problems as they emerge?
1
2
3
4
5

How effective is your organization at identifying future problems before they emerge?

1

2

3

4

5

\section{Defining and scoping a problem}

Once a problem has been identified, to what extent does your i organization communicate internally when defining and scoping the problem?
1
2
3
4
5

To what extent does your organization communicate with other institutions in the organisation when defining and scoping a problem?
1
2
3
4
5

To what extent does your organization seek to bring in perspectives from outside the organisation when defining and scoping a problem?
1
2
3
4
5

How effective is your organization at developing an agreed or shared understanding of a particular problem (i.e. an understanding that reflects the variety of perspectives)?

1

2

3

4

5

To what extent does your organization seek information about past experiences of the organisation when defining and scoping a problem?

$\begin{array}{lllll}1 & 2 & 3 & 4 & 5 \\ & & 126 & \end{array}$




\section{Evaluating solutions to a problem}

How effective is your organization at taking a proactive approach to dealing with future (anticipated) problems, before they emerge?

$\begin{array}{lllll}1 & 2 & 3 & 4 & 5\end{array}$

To what extent does your organization communicate with other institutions organisation when formulating potential solutions to a problem?

$\begin{array}{lllll}1 & 2 & 3 & 4 & 5\end{array}$

To what extent does your organization seek to bring in perspectives from outside the organisation when formulating potential solutions to a problem?

$\begin{array}{lllll}1 & 2 & 3 & 4 & 5\end{array}$

To what extent does your organization seek information about past experiences of the organisation when formulating potential solutions to a problem?

$\begin{array}{lllll}1 & 2 & 3 & 4 & 5\end{array}$

When formulating potential solutions to a problem, to what extent does your organization stick to well-known, 'tried and true' measures?

$\begin{array}{lllll}1 & 2 & 3 & 4 & 5\end{array}$

To what extent does your organization experiment with new and innovative solutions?

$\begin{array}{lllll}1 & 2 & 3 & 4 & 5\end{array}$

To what extent does your organization favour reversible measures over irreversible ones?

$\begin{array}{lllll}1 & 2 & 3 & 4 & 5\end{array}$

To what extent does your organization see a problem as an opportunity for creative thinking and innovation?

$\begin{array}{lllll}1 & 2 & 3 & 4 & 5\end{array}$ 
How effective is your organization at developing clear, actionable solutions to a problem?

How effective is your organization at developing and selecting solutions even in the face of uncertainty or incomplete information?

\section{$\underline{\text { 5. Implementingsolutions }}$}

When implementing solutions, to what extent does your organization monitor theimpacts/ effectiveness of those solutions in the short-term? In the long (different response scales)
1
2
3
4
5

To what extent are the monitoring results (positive or negative) communicated within the organization? Outside the organization?
1
2
3
4
5

If a solution is seen to be not working, to what extent does your organization adjust the solution and/ or its implementation?
1
2
3
4
5

To what extent are the established processes of finding, defining and problems revised in light of new experiences and/ or new information?

\section{General comments}

